DOE/EM-0255

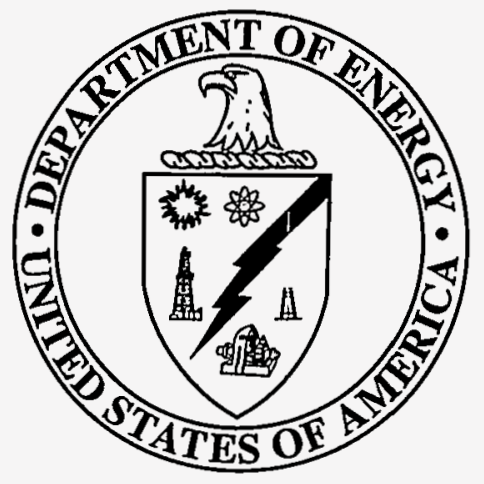

Office of Environmental Management Technology Development

\title{
RADIOACTIVE TANK WASTE REMEDIATION FOCUS AREA
}

\section{Technology Summary}

\section{June 1995}




\section{DISCLAIMER}

This report was prepared as an account of work sponsored by an agency of the United States Government. Neither the United States Government nor any agency thereof, nor any of their employees, makes any warranty, express or implied, or assumes any legal liability or responsibility for the accuracy, completeness, or usefulness of any information, apparatus, product, or process disclosed, or represents that its use would not infringe privately owned rights. Reference herein to any specific commercial product, process, or service by trade name, trademark, manufacturer, or otherwise does not necessarily constitute or imply its endorsement, recommendation, or favoring by the United States Government or any agency thereof. The views and opinions of authors expressed herein do not necessarily state or reflect those of the United States Government or any agency thereof.

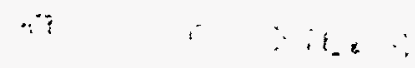




\section{DISCLAIMER}

Portions of this document may be illegible in electronic image products. Images are produced from the best available original document. 


\section{TANK FOCUS AREA TECHNOLOGY SUMMARY}

\section{TABLE OF CONTENTS}

Introduction iii

Tank Focus Area Overview ....................................................................................................

1.0 CHARACTERIZATION SUBPROGRAM OVERVIEW ............................................ 3

1.1 Light Duty Utility Arm System ……….....................................................................

1.2 Characterization Field Support System For In Situ Characterization of

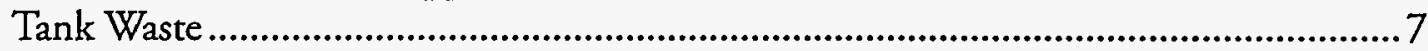

1.3 Fiber-Optic Near-Infrared Spectrometer Systems ......................................................9

1.4 Fiber-Optic Laser Raman Spectroscopies for Tank Waste Characterization .................. 11

1.5 Non-Contact Imaging Raman Spectroscopy …………............................................ 15

1.6 Laser Range Finder and Structured Light Mapping Systems ........................................ 18

1.7 Physical Properties End-Effector for Light Duty Utility Arm ......................................21

1.8 Acoustic Emission Method for Detection of Pipeline Leaks ...........................................23

2.0 WASTE DISLODGING AND CONVEYANCE SUBPROGRAM OVERVIEW ......... 29

2.1 High/Medium Pressure Water Jet End Effectors ...........................................................30

2.2 Mechanics and Hydraulics Testbed ................................................................................... 33

3.0 WASTE PROCESSING AND DISPOSAL SUBPROGRAM OVERVIEW .................... 39

3.1 Cesium Removal Demonstration for Radioactive Waste Treatment .............................40

3.2 Resorcinol/Formaldehyde Resin for Elutable Ion Exchange in Compact

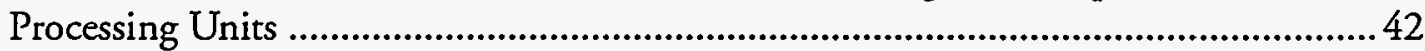

3.3 Comprehensive Supernate Demonstration, Testing, and Evaluation ...........................44

3.4 TRUEX Model Development........................................................................................4 47

3.5 The Nitrate to Ammonia and Ceramic Process .............................................................49

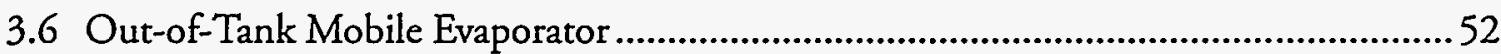

3.7 Crossflow Filtration Technology ....................................................................................5

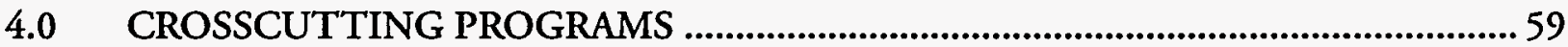

5.0 SITE SPECIFIC TECHNOLOGY DEVELOPMENT ACTIVITIES............................. 63

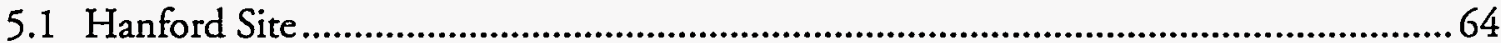

5.2 Idaho National Engineering Laboratory ........................................................................

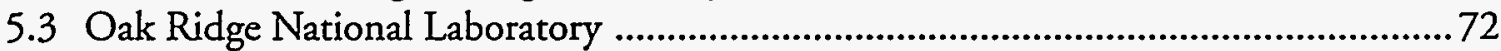

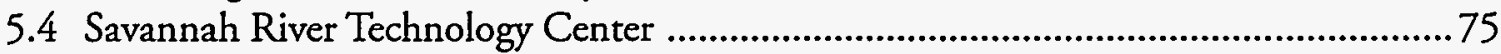

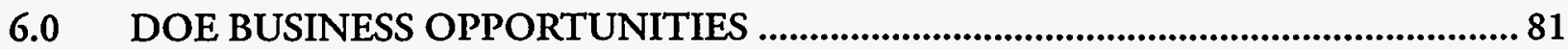

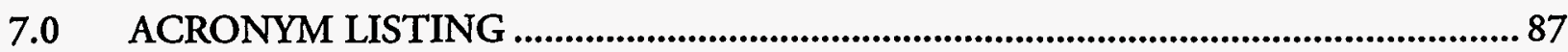

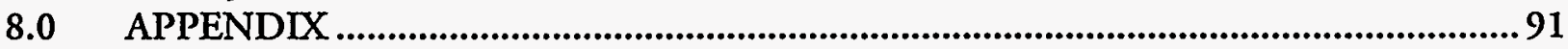




\begin{tabular}{|c|c|}
\hline \multicolumn{2}{|l|}{ Figures } \\
\hline A. & 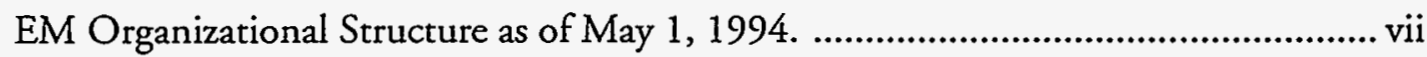 \\
\hline B. & OTD Organizational Structure as of May 1, $1994 .$. \\
\hline C. & Typical Single-Shell Tank.................... \\
\hline 1.1 & The Light Duty Utility Arm System ... \\
\hline 1.2 & Field Support System.. \\
\hline $1.4 \mathrm{a}$ & 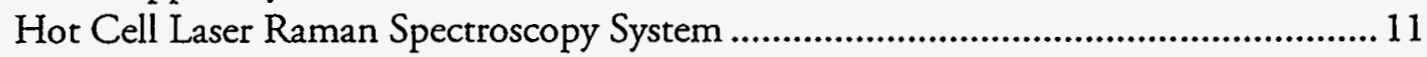 \\
\hline $1.4 \mathrm{~b}$ & Laser Raman Spectra of Various Nitrate-Containing Materials ................................ 12 \\
\hline 1.5 & 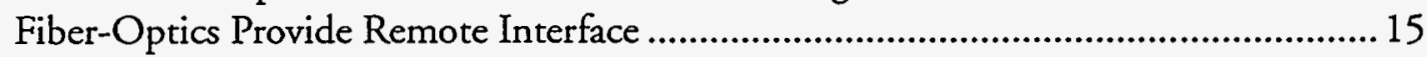 \\
\hline $1.6 \mathrm{a}$ & World View After First Rough Cut by Laser Range Finder ........................................ 18 \\
\hline $1.6 b$ & LDUA Structured Light Surface Mapping Conceptual Design for Sensor Probe ........ 19 \\
\hline $1.6 \mathrm{c}$ & LDUA Structured Light Surface Mapping Sensor Probe Operation ............................20 \\
\hline 1.8 & 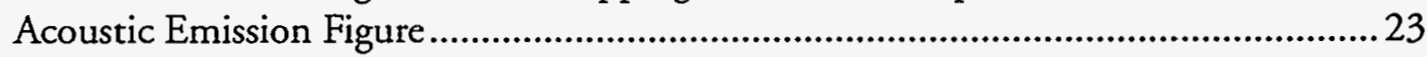 \\
\hline 2.1 & 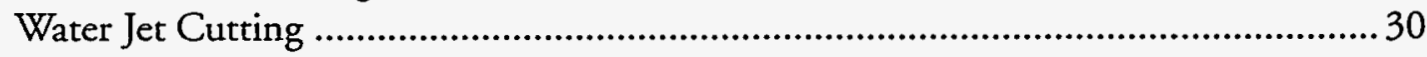 \\
\hline 2.2 & Hydraulic Testbed . \\
\hline 3.2 & Resorcinol-Formaldehyde Resin . \\
\hline $3.4 \mathrm{a}$ & CMPO-Extractant Structural Formula \\
\hline $3.4 \mathrm{~b}$ & TRUEX-Process Extraction Equilibrium Example .................................................4 47 \\
\hline 3.5 & 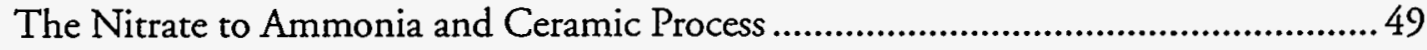 \\
\hline
\end{tabular}




\section{INTRODUCTION}

\section{THE NEW APPROACH}

\section{PURPOSE}

Although positive steps have been taken during the past three decades to remedy the world's environmental problems, the nation's ability to respond to many current and future environmental and economic challenges depends on technological advances produced by a well-organized and productive federal research and development program.

To ensure that such programs focus on the most pressing environmental restoration and waste management problems at the U.S. Department of Energy (DOE), the Assistant Secretary for the Office of Environmental Management (EM) established a Working Group in August 1993 to implement a new approach to environmental research and technology development. The goal of DOE's new approach is to conduct a research and technology development program that will overcome major obstacles in the cleanup of DOE sites. Integral to this new, solutions-oriented approach is an up-front awareness of program needs obtained from customers, users, regulators, and stakeholders. These needs can then be disseminated to the developers of technological solutions.

The key features of the new approach are:

- establishing five focus areas to address DOE's most pressing problems;

- teaming with the customers in EM to identify, develop, and implement needed technology;

- focusing technology development activities on major environmental management problems;

- coordinating management of scientific and development activities in support of EM;

- focusing resources in national laboratories more effectively;

- involving industry in developing and implementing solutions, including technology transfer into DOE and from DOE to the private sector;

- coordinating basic research by involving academia and other research organizations to stimulate technological breakthroughs; and

- enhancing involvement of regulators and stakeholders in implementation of technology development.

DOE has established a framework and strategy for coordinating efforts among DOE organizations, Management and Operations $(\mathrm{M} \& \mathrm{O})$ contractors, the national laboratories, other government agencies, the scientific community, industry, academia, and the affected public. Full implementation of the new approach is planned for the FY 95/96 timeframe. The new strategy will build upon existing programs and will seek continual improvement of all EM operations and processes.

Prior to implementation of the new approach, EM's Office of Technology Development (OTD) carried out an aggressive national program of applied research and development to meet environmental restoration and waste management needs based on the concepts of Integrated Programs (IP) and Integrated Demonstrations (ID). These concepts, introduced in 1989, were engineered to manage the research, development, demonstration, testing and evaluation (RDDT\&E) activities within EM.

An IP was the cost-effective mechanism which assembled a group of related and synergistic technologies to evaluate their performance to solve a specific aspect of a waste management or environmental problem. The problem could be unique to a site or common to many sites. An IP supported applied research to develop innovative technologies in key application areas organized around specific activities required in each stage of the remediation process (e.g., characterization, treatment, and disposal). 
An ID was the cost-effective mechanism that assembled a group of related and synergistic technologies to evaluate their performance individually or as a complete system to correct waste management and environmental problems from cradle to grave.

\section{BENEFITS}

A keystone for implementation of the new approach is to encourage development of technologies that are better, faster, safer and more cost-effective than those currently available. More importantly, the new approach has been adopted to foster implementation of new and innovative environmental technologies, facilitating the national commitment to long-term environmental, energy, and economic goals.

An important benefit to the new approach is the creation of investment returns for developing new technologies and technology dividends. These technology dividends result from partnerships and leveraging within government and between government and the private sector. The partnerships can consist of technology developers, technology users, problem holders, and problem solvers.

EM technology dividends will include:

- Cleanup of sites posing the greatest threats to human health, safety, and the environment;

- Materials reused and recycled, instead of thrown away or freshly contaminated;

- Pollution prevention;

- Employment opportunities with new businesses and existing businesses;

- More effective and efficient industrial processes, leading to greater U.S. competitiveness globally; and

- Technology transfer to other countries.

By implementing the new approach for the unique environmental problems associated with DOE sites, EM/ OTD, scientists, and engineers at the national laboratories stand at the threshold of opportunity to develop new technologies. This work will enhance quality of life through a cleaner environment, improved global competitiveness, and ensure job opportunities for American workers.

\section{FOCUS AREAS}

Five major remediation and waste management problem areas within the DOE Complex have been targeted for action on the basis of risk, prevalence, or need for technology development to meet environmental requirements and regulations. Other areas may be added or currently identified areas further partitioned to ensure that research and technology development programs remain focused on EM's most pressing remediation and waste management needs. These major problem areas, termed "Focus Areas," are described below.

Contaminant Plume Containment and Remediation. Uncontained hazardous and radioactive contaminants in soil and ground water exist throughout the DOE Complex. There is insufficient information at most sites on the contaminants' distribution and concentration. The migration of some contaminants threatens water resources and, in some cases, has already had an adverse impact on the off-site environment. Many current characterization, containment, and treatment technologies are ineffective or too costly. Improvements are needed in characterization and data interpretation methods, containment systems, and in situ treatment.

Mixed Waste Characterization, Treatment, and Disposal. DOE faces major technical challenges in the management of low-level radioactive mixed waste. Several conflicting regulations, together with a lack of definitive mixed waste treatment standards hamper mixed waste treatment and disposal. Disposal capacity for mixed waste is also expensive and severely limited. DOE now spends millions of dollars annually to store 
mixed waste because of the lack of accepted treatment technology and disposal capacity. In addition, currently available waste management practices require extensive, and hence costly waste characterization before disposal. Therefore, DOE must pursue technology that leads to better and less expensive characterization, retrieval, handling, treatment, and disposal of mixed waste.

High-Level Waste Tank Remediation. Across the DOE Complex, hundreds of large storage tanks contain hundreds of thousands of cubic meters of high-level mixed waste. Primary areas of concern are deteriorating tank structures and consequent leakage of their contents. Research and technology development activities must focus on the development of safe, reliable, cost-effective methods for characterization, retrieval, treatment, and final disposal of the wastes.

Landfill Stabilization. Numerous DOE landfills pose significant remediation challenges. Some existing landfills have contaminants that are migrating, thus requiring interim containment prior to final remediation. Materials buried in retrievable storage pose another problem. Retrieval systems must be developed to reduce worker exposure and secondary waste quantities. Another high-priority need is in situ methods for containment and treatment.

Decontamination and Decommissioning. The aging of DOE's weapons facilities, along with the reduction in nuclear weapons production, has resulted in a need to transition, decommission, deactivate, and dispose of numerous facilities contaminated with radionuclides and hazardous materials. While building and scrap materials at the sites are a potential resource, with a significant economic value, current regulations lack clear release standards. This indirectly discourages the recovery, recycling, and/or reuse of these resources. The development of enhanced technologies for the decontamination of these materials, and effective communication of the low relative risks involved, will facilitate the recovery, recycle, and/or reuse of these resources. Improved material removal, handling, and processing technologies will enhance worker safety and reduce cost.

\section{CROSSCUTTING TECHNOLOGIES}

Crosscutting technologies are those which overlap the boundaries of the focus areas while providing simultaneous benefits. These technologies may be used in several or all focus area testing and evaluation programs, and include:

Characterization, Monitoring, and Sensor Technology. DOE is required to characterize more than 3,700 contaminated sites, 1.5 million barrels of stored waste, 385,000 cubic meters of high-level waste in tanks, and from 1,700 to 7,000 facilities before remediation, treatment, and facility transitioning commence. During remediation, treatment, and site closure, monitoring technologies are needed to ensure worker safety and effective cleanup. Cost-effective technologies are needed for all EM characterization requirements.

Efficient Separations and Processing. Separation and treatment technologies are needed to treat and immobilize a broad range of radioactive wastes. In some cases, separations technologies do not exist. In others, improvements are needed to reduce costs, reduce secondary waste volumes, and improve waste form quality. Separations technologies are also needed for environmental restoration of DOE sites, for groundwater and soils cleanup, and for decontamination and decommissioning of facilities. Many separations agents developed for waste treatment can be adapted for environmental restoration needs.

Robotics. DOE's waste disposal efforts have particular issues such as access problem, safety, final disposal, and cost efficiency. Due to hazardous radiation, massive waste loads, and restricted entry ways, many sites are inaccessible for human labor. 
Using Robotics eliminates the problems of exposing humans to radiation, harmful chemicals, injurious mechanical objects, expensive protective clothing, stringent decontamination procedures and higher compensation of human labor. Robotic systems are safe, efficient and cost-effective means to automate the handling and processing of the mixed waste and characterizing and/or retrieving storage tank waste. Systems can also be designed for surveillance, characterization, cleanup, and decommissioning of retired DOE facilities.

Innovative Investment Area. DOE has set aside funding to foster research and development partnerships within the public and private sector, and to introduce innovative technologies into OTD programs. The Innovative Investment Area supports two types of technologies: (1) technologies that show promise to address specific EM needs, but require proof-of-principle experimentation, and (2) proven technologies in other fields that require critical path experimentation to demonstrate feasibility for adaptation to specific EM needs.

Pollution Prevention. DOE and the Department of Defense (DoD) have similar waste stream pollution problems and common environmental concerns. By combining their resources, these agencies can develop a coordinated interagency environmental research and technology development program that produces cost-effective technological solutions, particularly in the areas of process change or in-process recycling.

\section{TECHNICAL TASK PLANS}

Technical Task Plans (TTPs) are used to identify and to summarize work funded and managed by OTD at headquarters, the field, and the national laboratories. These plans include a project summary, technical task description, budget schedule, and milestone schedule. The EM-50 FY 1994 Program Summary (DOE/ EM-0216) lists TTPs current as of the date of this document.

All tasks require a TTP number. Each TTP number contains information on the fiscal year in which the task is first funded, the DOE Operations Office funding allotment code, and the laboratory/contractor/ university designator (see Appendix for further details).

\section{EM ORGANIZATIONAL STRUCTURE}

The Office of Environmental Management (EM) is responsible for managing the cleanup of DOE wastes from past nuclear weapons production and current operations. The EM mission is to bring DOE sites into compliance with all environmental regulations while minimizing risks to the environment, human health and safery posed by the generation, handling, treatment, storage, transportation, and disposal of DOE waste. The EM organization was established to provide focus, accountability, and visibility for DOE's waste management and remediation efforts. See Figure A.

\section{OFFICE OF TECHNOLOGY DEVELOPMENT}

The Office of Technology Development (EM-50) has the overall responsibility to develop technologies to meet DOE's goals for environmental restoration. OTD works closely with EM-30, -40 , and -60 in identifying, developing, and implementing innovative and cost-effective technologies. Activities within EM-50 include applied research and development, demonstration, testing, and evaluation (RDDT\&E), technology integration, technology transfer, and program support. See Figure B.

\section{EM-50 ORGANIZATION}

The Office of Technology Transfer and Program Integration (EM-52) provides management, financial, and internal program support to line organizations that comprise EM-50. It also promotes efforts to encourage and to facilitate the infusion and diffusion of innovative environmental technologies for internal and domestic application through 
collaborative partnerships with U.S. and foreign industry or organizations, the national laboratories, other federal agencies, and universities. Technology transfer and technology leveraging are important program components. Enhanced communication to internal and external stakeholders is a goal of this Office.

The Office of Research and Development (EM-53) is responsible for establishing an applied research and development (R\&D) program at DOE sites nationwide. Programs are designed to identify operational needs in environmental restoration, waste operations, and corrective activities, and to provide solutions to key technical issues that, if not solved in a timely manner, would adversely affect DOE's ability to meet its cleanup goal.

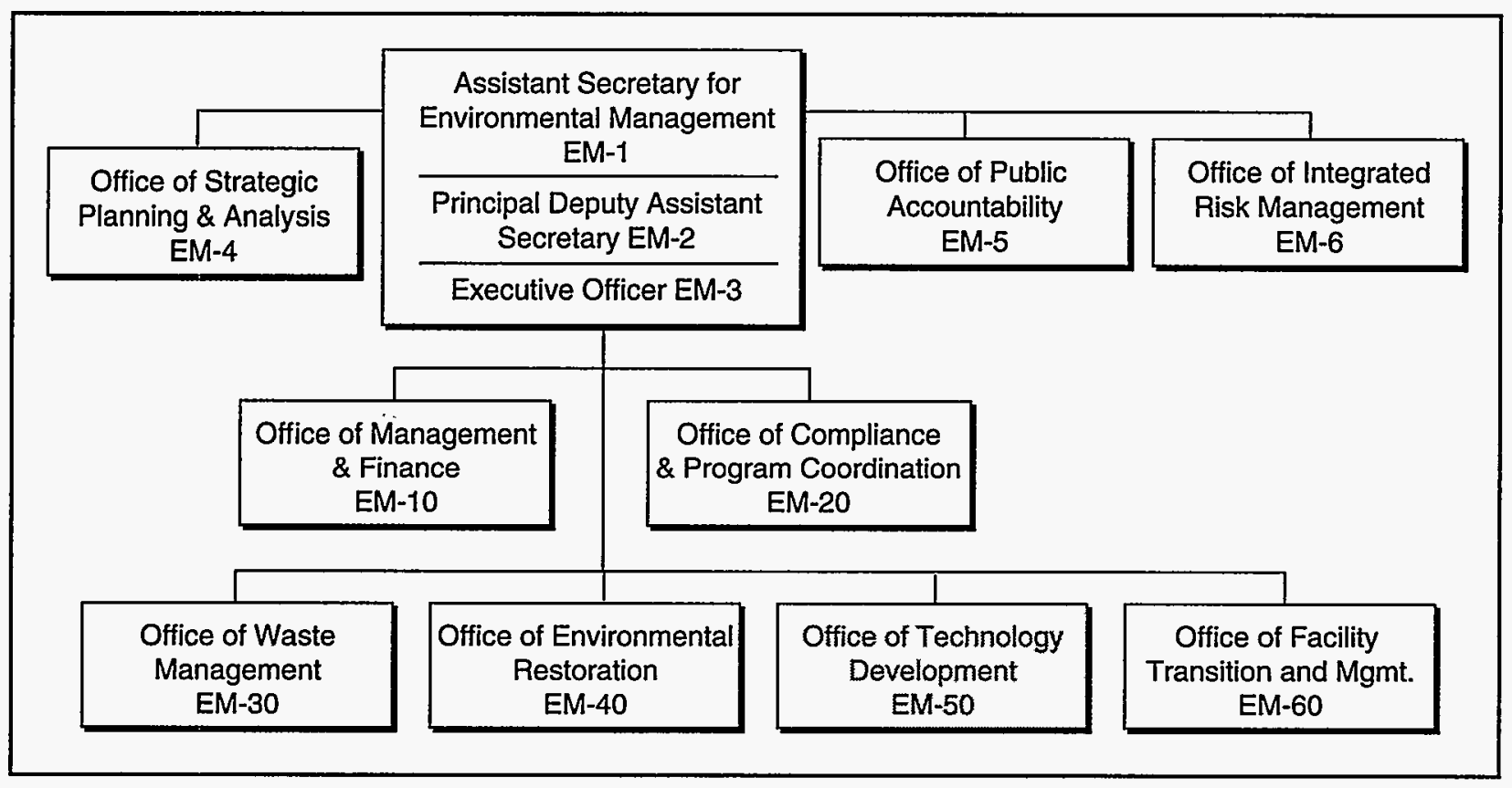

Figure A. The EM Organizational Structure as of May 1, 1994.

The Office of Demonstration, Testing, and Evaluation (EM-54) is responsible for identifying environmental management technologies in the research and development stage that are ready for transition to the demonstration arena. Those technologies are complete systems to demonstrate a solution to a specific problem area. Programs are conducted to advance selected technologies so they can be used by DOE to meet its cleanup goal in a cost-effective manner.

\section{OTHER EM ORGANIZATIONS}

The Office of Waste Management (EM-30) has program responsibilities for managing waste generated at all DOE sites during weapons processing and manufacturing, research activities, and site cleanup activities. This includes the treatment, storage, transportation, and disposal of several types of waste: transuranic, low-level radioactive, mixed, and solid sanitary wastes. EM-30 is also responsible for the storage, treatment, and processing of defense high-level radioactive waste (HLW), waste minimization efforts, and corrective activities at waste management facilities.

The Office of Environmental Restoration (EM-40) has program responsibilities for assessment and cleanup of inactive hazardous and radioactive facilities and waste sites at all DOE installations and some non-DOE sites. EM-40 oversees program activities to reduce or eliminate risks to human health and the environment. 


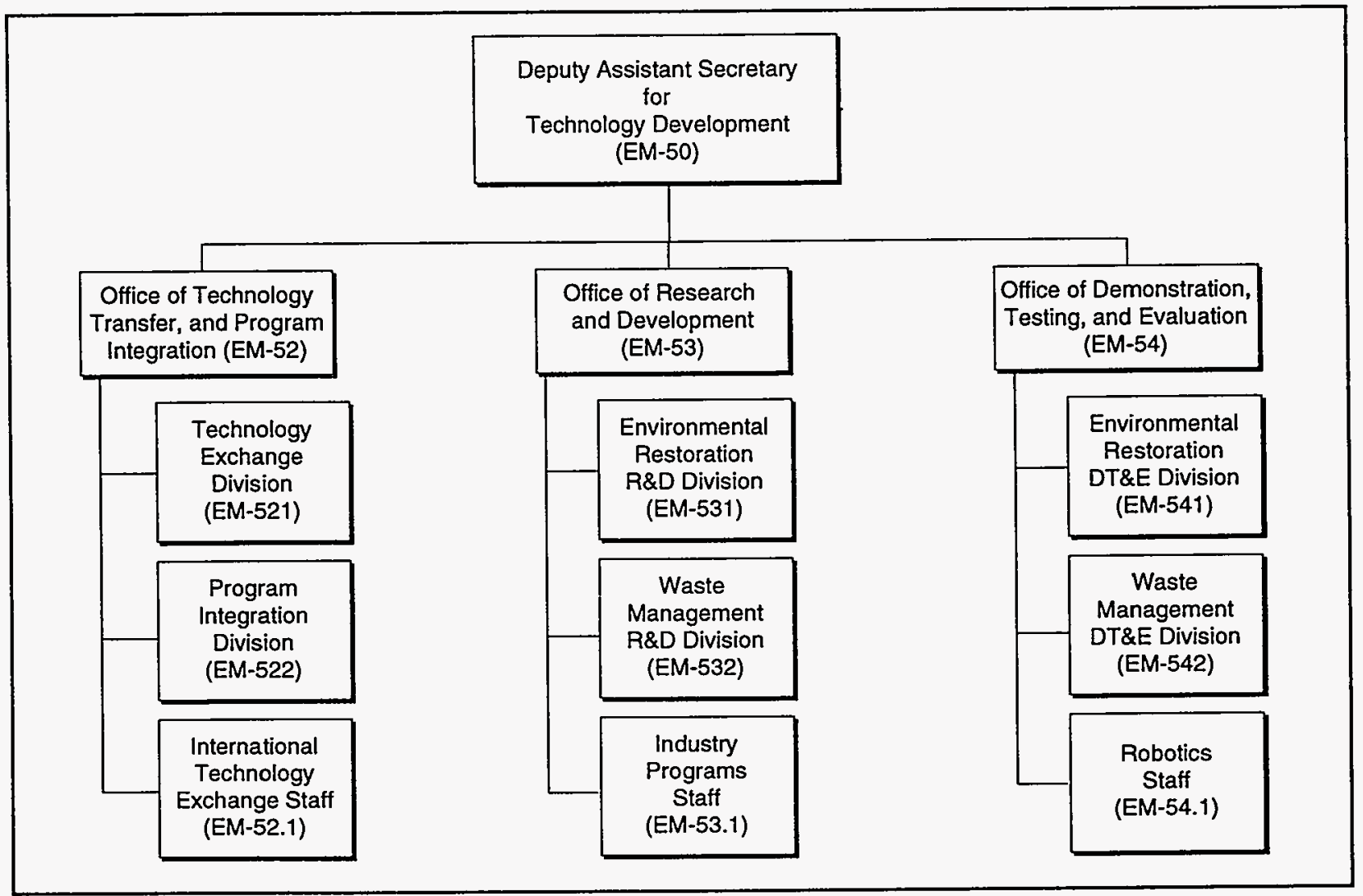

Figure B. The OTD Organizational Structure as of May 1, 1994.

The Office of Facility Transition and Management (EM-60) has the responsibility to ensure that shut-down facilities are brought to a deactivated state, are properly maintained, and are eventually decontaminated and/or decommissioned or released for other uses. 


\section{TANK FOCUS AREA OVERVIEW}

\section{THE CHALlENGE}

Within the DOE Complex, 332 underground storage tanks (USTs) have been used to process and store radioactive and chemical mixed waste generated from weapon materials production. Together, these tanks hold more than 100 million gallons of high-level and low-level radioactive liquid waste, very little of which has been treated and disposed of in final form.

Two waste storage tank types are prevalent: single-shell wall and double-shell wall designs. See Figure C. These tanks are made of stainless steel, concrete, and concrete with carbon steel liners. Their capacities vary from 5,000 gallons $\left(19 \mathrm{~m}^{3}\right)$ to $1,000,000$ gallons $\left(3,785 \mathrm{~m}^{3}\right)$. The USTs are covered with a layer of soil ranging from a few feet to tens of feet thick.

Tank waste consists of several physical forms: sludge, supernate, and salt cake. Most of the waste is alkaline and contains the following chemical constituents: nitrate and nitrite salts (approximately half of the total waste), hydrated metal oxides, phosphate precipitates, and ferrocyanides. The $640 \mathrm{MCi}$ of radionuclides are distributed primarily among the transuranic (TRU) elements and fission products, primarily strontium90 and cesium-137. In-tank atmospheric conditions vary in severity from near ambient to temperatures over $93^{\circ} \mathrm{C}$. Tank void-space radiation fields can be as high as $10,000 \mathrm{rad} / \mathrm{h}$.

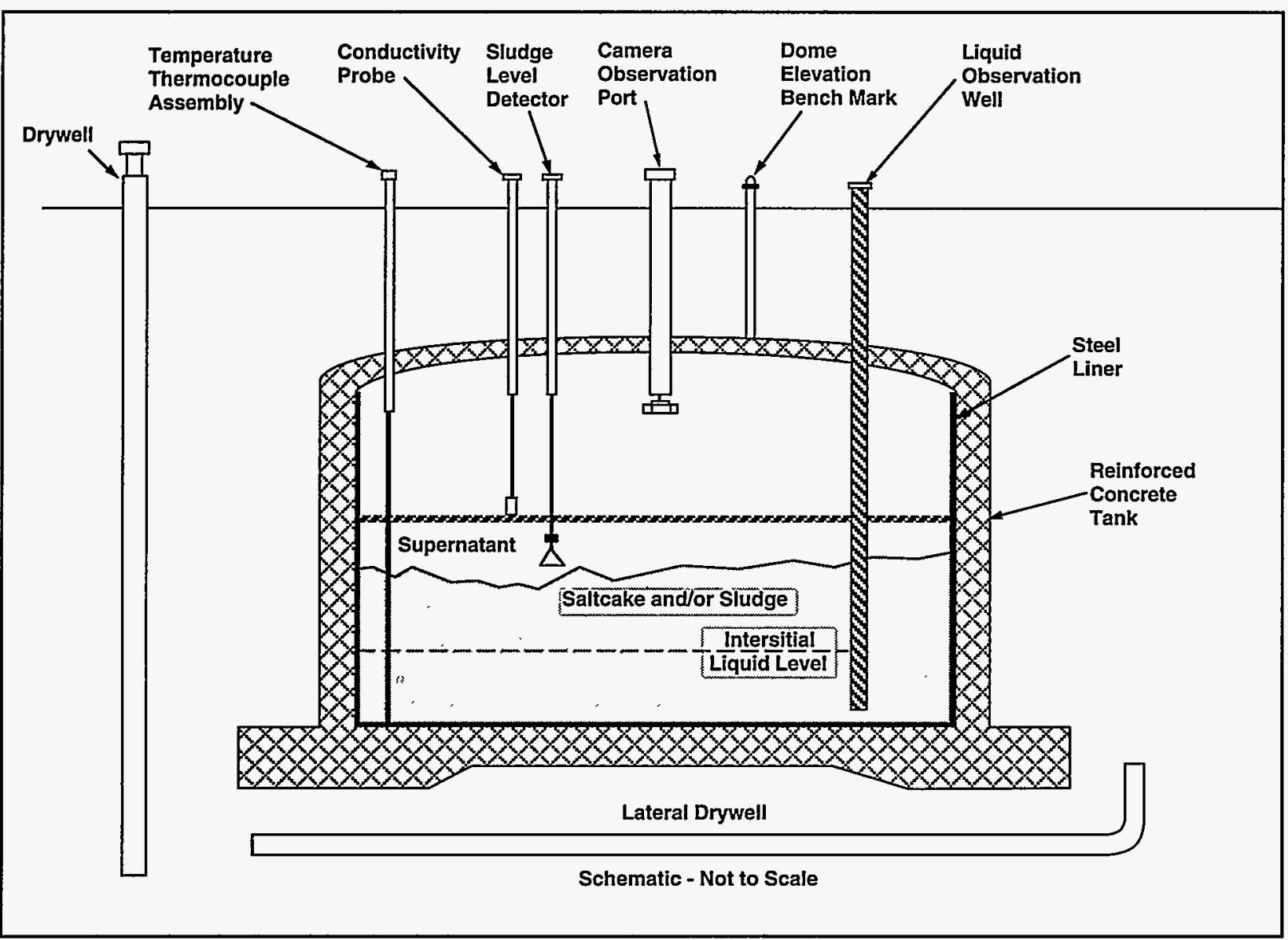

Figure C. Typical Single-Shell Tank. 
In February 1991, DOE's Office of Technology Development created the Underground Storage Tank Integrated Demonstration (UST-ID), to develop technologies for tank remediation. Tank remediation across the DOE Complex has been driven by Federal Facility Compliance Agreements with individual sites. In 1994, the DOE Office of Environmental Management created the High Level Waste Tank Remediation Focus Area (TFA; of which UST-ID is now a part) to better integrate and coordinate tank waste remediation technology development efforts. The mission of both organizations is the same: to focus the development, testing, and evaluation of remediation technologies within a system architecture to characterize, retrieve, treat, concentrate, and dispose of radioactive waste stored in USTs at DOE facilities. The ultimate goal is to provide safe and cost-effective solutions that are acceptable to both the public and regulators.

The TFA has focused on four DOE locations:

- the Hanford Site in Richland, Washington,

- the Idaho National Engineering Laboratory (INEL) near Idaho Falls, Idaho,

- the Oak Ridge Reservation in Oak Ridge, Tennessee, and

- the Savannah River Site (SRS) in Aiken, South Carolina.

Hanford has 177 tanks that hold over 60 percent of the total DOE tank waste. Most of these are singleshell tanks that have exceeded their life expectancy and are leaking. Due to several changes in the production processes since the early 1940s, some of the tanks contain incompatible waste components, generating hydrogen and excess heat that further risk tank integrity.

The TFA has focused its technology development in areas where currently available technology does not meet technical and safety requirements for tank waste remediation. Six problem areas are shared by most of the parricipant sites, and have been designated as sub-program elements. They are:

- Waste characterization,

- Waste retrieval and conveyance,

- Waste separation and pretreatment,

- Low-level waste treatment and disposal,

- Waste immobilization, and

- Site closure.

Historically, characterization of tank waste has been very expensive, has failed to obtain representative data for many tanks, and has generated safety concerns from worker exposure to radioactive waste. The TFA is developing sensors to identify chemical and physical characteristics of the waste inside the tank, improving data quality and timeliness, and reducing safety concerns. Fiber Optic Laser Raman spectroscopy is one example of a waste analysis sensor. The Raman spectrometer and infrared spectroscopy systems have been demonstrated on real waste in a hot cell, setting the stage for the development of a multi-sensor systems for placement in tanks. A contract has been placed with SPAR Aerospace for design and construction of a Light Duty Utility Arm to deploy characterization sensors in tanks.

Together with OTD's Robotics Crosscutting Program, the TFA is developing remotely controlled waste retrieval devices capable of dislodging the sludge and saltcake fractions of the wastes and conveying them from the tanks. These devices are designed to fit through 12-inch diameter access ports, and to work in highly radioactive environments. The TFA recently completed testing of the Soft Waste Dislodging Tool and air conveyance system on a waste simulant. This test demonstrated control of intelligent end effectors, and conducted extensive tests of waste dislodging and conveyance end effectors for the first generation Long Reach Arm. 
Waste separation techniques will separate tank wastes into low-level, TRU, and high-level fractions, thereby significantly reducing the volumes of high-level wastes requiring costly disposal. Low-level waste (LLW) treatment will reduce waste volumes and produce waste forms that are chemically and physically durable.

Successes in waste processing have included the initiation of hot cell testing of liter quantity volumes of sludge and supernate for processing of Oak Ridge Melton Valley Storage Tank wastes, and completion of a preliminary design for a mobile evaporator to concentrate tank waste. Researchers have completed leachability tests for both polyethylene and alumina-based ceramic waste forms.

Site closure technologies, which consist of a variety of containment barriers capturing effluents leaking from the tanks, are currently being developed by related programs. See the Landfill and Plume Focus Area Technology Summary books for more information on barrier technology.

The TFA secures the active involvernent of private industry, universities, and other government agencies through establishing collaborative partnerships (CRADAs), licensing of technologies, fostering technical personnel exchanges, effecting consulting agreements, and prompting shared use of scientific facilities.

A number of the technologies developed under the TFA will be transferrable to other applications outside the DOE Complex. Newly developed characterization technologies will be used in tanks and pipes containing materials other than waste and chemical manufacturing lines. The retrieval technologies developed may contribute to automation-assisted manufacturing, non-radioactive waste management, underwater mining and retrieval operations, and nuclear power plant operations. New barrier technologies will be more robust than those currently employed and will contribute to the ability to isolate non-nuclear contaminants.

\title{
For more information, please contact:
}

\author{
David Geiser \\ Program Manager \\ U.S. Department of Energy \\ Office of Technology Development, EM-54-Cloverleaf \\ 19901 Germantown Rd.
}

Germantown, MD 20874-1290 


\section{CHARACTERIZATION}

\section{Section 1.0}




\subsection{CHARACTERIZATION SUBPROGRAM OVERVIEW}

DOE has committed itself to safe and complete remediation of high-level waste (HLW) stored in underground storage tanks across the DOE Complex. OTD has undertaken the task of developing new technologies for safe, expedient, and cost-effective remediation of HLW in tanks. TFA is developing technologies which focus on HLW tank remediation.

Safe remediation of HLW from tanks is impossible without knowledge of the chemical and radioactive composition and physical parameters of the waste. The TFA Characterization Subprogram is developing technologies that identify chemical speciation, measure rheological properties such as density and viscosity, and determine moisture and TRU content. All of the sensors being developed will be capable of being used directly inside tanks. In situ characterization of tank waste can be more accurate than hot cell analysis, because it eliminates the time delay between sample removal and sample analysis. In situ analysis also decreases the cost of waste analysis, currently performed manually in laboratories on tank core samples. Most important, remote analysis eliminates sample handling and the safety concerns of worker exposure.

Laser Raman and infrared spectrographic methods are being developed for in situ chemical speciation analysis. Near infrared spectroscopic sensors are being developed for moisture content analysis. Two methods are being pursued for topographical mapping of the waste surface inside the tanks: Laser Range Finder and Structured Light Mapping System. The Laser Range Finder will provide quick, coarse mapping of the tank interior. The structured light system will be used for detailed mapping of the tank interior. These topographical mapping systems will be used for the planning of retrieval operations. The TFA is also developing a remotely operated, robotic arm, called the Light Duty Utility Arm, to deploy and position these characterization and surveillance instruments in the tank. The arm and the sensors will be hardened against the hostile elements (radiation, caustics, water vapor, etc.) present in the tank surroundings.

Since the potential for tank leakage increases during retrieval operations, many of the Tanks are structurally unsound, and sluicing-based retrieval will add water to tanks, TFA in addition to in-tank hardware is working with a consortium of government and industry to develop an acoustic emission system to detect and locate leaks in underground pipe line systems. 


\subsection{LIGHT DUTY UTILITY ARM SYSTEM}

\section{TASK DESCRIPTION}

The TFA is developing a Light Duty Utility Arm (LDUA) system. This integrated robotic deployment system will be able to perform inspection, surveillance, waste analysis, and small-scale retrieval tasks in USTs. Current methods used at DOE tank sites are limited to positioning sensors, instruments, and devices to locations directly below access penetrations.

The LDUA system will provide a mobile, robotic deployment platform to perform tank structural integrity assessments and examine the characteristics and properties of the waste. A critical limitation in planning the safe remediation of these tanks is the lack of detailed, qualitative information on tank conditions, and characteristics of the stored waste materials. This information is needed to support ongoing stabilization and monitoring programs, and to plan for future retrieval and processing of the tank waste. The sensors, or "end effectors", for collecting this data are also being developed by the Tank Focus Area, and are described in Sections 1.3 -1.7 of this book.

The LDUA system's design is flexible and adaptive. It can perform remote operations through limited access openings and in areas containing potentially dangerous materials. Although the system targets DOE tank remediation programs, there are many other potential applications within the DOE Complex, the commercial nuclear industry, and other industries where hazardous materials or conditions limit human entry for examination, maintenance, or response to failures. See Figure 1.1.

The LDUA system will use a mobile multiaxial positioning system to access the underground storage tanks through existing 12-inch diameter riser penetrations located in the tank dome. Other ancillary system equipment will be deployed through existing four inch diameter riser penetrations. The system provides the capability to deploy remotely

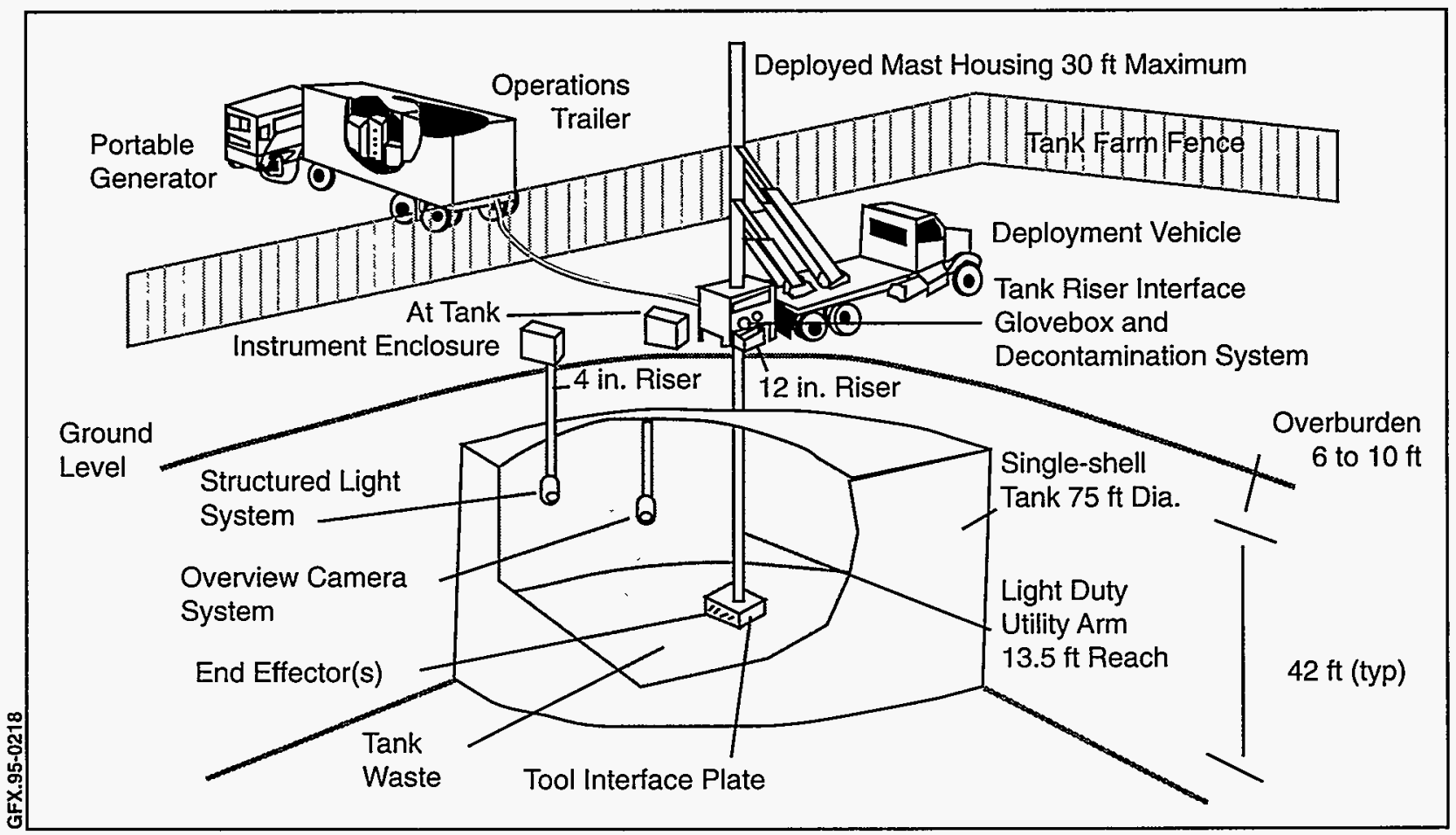

Figure 1.1 The Light Duty Utility Arm System. 
operated end effectors at multiple elevations and positions within the tank, using a robotic manipulator arm mounted on a telescoping mast.

The LDUA system is functionally divided into major equipment subsystems and additional ancillary and support equipment, including:

- Arm and deployment,

- Tank riser interface and confinement (TRIC),

- Operations control center,

- End effectors,

- Various utilities and interface equipment that support multiple subsystems.

The LDUA can be operated in either remote or automated modes. The manipulator arm will provide a radial reach of at least $13.5 \mathrm{ft}$ from the tank riser centerline. The kinematic design, based on seven degrees of freedom, results in a highly dexterous positioning capability. The arm can lift at least 50 lbs at maximum extension, with the capability to lift end effectors up to $75 \mathrm{lbs}$ with some compromise to the system accuracy parameters. The deployment mast will provide extension to at least $62.5 \mathrm{ft}$ to access the full tank depth.

\section{TECHNOLOGY NEEDS}

In large USTs that have been in operation for several decades, the areas directly below the access risers are often disturbed or contain a significant amount of discarded debris. Therefore, evaluation of tank waste characteristics by measurements taken at these locations may not be representative of the properties of the waste in other areas of the tanks. The LDUA system can deploy sensors and other devices in locations away from the area directly below the access risers. This capability is particularly important for analyzing the waste materials in the tank.

The capability to perform close-up examinations of the tank walls is not currently available. Inspection of single-shell tanks is limited to videos or still photography taken from positions directly below access risers. Visual examinations with current photography and video systems provide useful but limited information.

The LDUA system equipment must withstand the radiation levels and highly corrosive atmospheres encountered in HLW tanks. Selection of appropriate materials, and radiation hardening of some equipment are being addressed in the LDUA system design. Equipment must also be amenable to decontamination and should be modular in design to allow for easy replacement of components.

\section{BENEFITS}

The value and benefit of existing and developing systems for in-tank operation will be greatly enhanced by the ability of the LDUA manipulator arm to position the analytical sensors, sampling devices, and cameras at many different positions across a large operating envelope in the tank. Other nondestructive examination methods proposed for the LDUA system will enable inspection of corrosion and pitting and quantitative measurement of tank wall thickness or cracks. In addition to nondestructive methods of examination, the potential use of the LDUA system to cut and remove small samples of tank walls for verification purposes is currently being discussed.

Current technology development related to armbased retrieval systems anticipates that advanced manipulative control and collision avoidance systems will be required to ensure that damage to the tank structure does not occur. Systems currently being investigated under other technology development programs will use a high-level supervisory control architecture similar in principle to the LDUA system. These systems will use a world model of the tank environment, which is created based on available information from engineering drawings and additional sensor data provided by topographical mapping systems. The LDUA system is developing several mapping systems that would be applicable to this need. These systems could be used in advance of a retrieval campaign to create a fairly accurate map of the tank interior. These data would be used by the high-level controller of the retrieval manipu- 
lator system for path planning and collision avoidance controls.

Pre- and post-retrieval mapping would reveal changes in the waste topography that could verify waste volume removed. This type of quantifiable measurement is likely to be required to meet federal facility compliance agreement commitments. LDUA mapping technologies may provide a method of obtaining quantifiable volumetric measurement data.

\section{ACCOMPLISHMENTS}

A contract was successfully placed with SPAR Aerospace Company of Toronto, Canada, to build and provide the robot arm. Three of the five LDUA systems allowed by the SPAR contract have been ordered by customers at Hanford, Idaho National Engineering Laboratory (INEL), and Oak Ridge.

A cold test facility has been installed at the Hanford site to test and qualify the system equipment for hot operations in underground storage tanks at Hanford and INEL. Following initial testing, the test facility will be used for operator training and certification, equipment troubleshooting, and continued applications development.

\section{COLLABORATION/TECHNOLOGY}

\section{TRANSFER}

The centerpiece component of the LDUA system is the robotic arm. This arm and its deployment system (including mobile platform, interface to the TRIC, telescoping vertical positioning mast and housing, and deployment vehicle) are all being developed by commercial companies. SPAR Aerospace is the prime contractor and supplier of the articulated arm. National Instruments is working with the TFA to develop the computer interface for the LDUA system.

\section{For more information, please contact:}

Jim Lee

Characterization and Retrieval

Program Manager

Sandia National Laboratories

Richland, WA 99352

(509) 376-7439

Betty A. Carteret

Principal Investigator

Westinghouse Hanford Company

P.O. Box 1970

Richland, WA 99352

(509) 376-7331

\section{Roger Christensen}

Technical Program Officer

U.S. Department of Energy

Richland Operations Office

P.O. Box 550

3230 Q Avenue

Richland, WA 99352

(509) 372-4606

TTP Number: RL401203

\section{BIBLIOGRAPHY OF KEY PUBLICATIONS}

B.A. Carteret, Light Duty Utility Arm System for Underground Storage Tank Applications, Westinghouse Hanford Company, Proceedings of the Sixth Topical Meeting on Robotics and Remote Systems, ANS Robotics and Remote Systems Division, February 1995.

B.A. Carteret, Underground Tank Assessment Using Hanford's Light Duty Utility Arm System, Westinghouse Hanford Company WHC-SA-1980FP, ANS Transactions, November 1993.

G.R. Kiebel, An Approach to Software Quality Assurance for Robotic Inspection Systems, Westinghouse Hanford Company WHC-SA-1977-FP, ANS Transactions, November 1993. 


\subsection{CHARACTERIZATION FIELD SUPPORT SYSTEM FOR IN SITU CHARACTERIZATION OF TANK WASTE}

\section{TASK DESCRIPTION}

Extensive characterization of tank waste is needed, and the integrity of the tanks must be assessed in order to appropriately remediate DOE's USTs. The TFA is developing a LDUA system to obtain this data. The purpose of this task is to develop a field support system, including a trailer containing data acquisition and control equipment.

The field support system provides the support infrastructure (operations trailer, power supplies, data and control systems, test equipment) to interface with a variety of instruments and deployment devices. Techniques for determining the physical, chemical, and radiological nature of UST wastes will be developed by others and integrated into a system design. The complete system will provide in situ, multi-sensor characterization and sampling capability for the USTs. See Figure 1.2. acquisition equipment, and test equipment. The Light Duty Utility Arm (LDUA) will be deployed with the following instruments:

- Raman spectrometer,

- Video and film camera,

- Radiation dosimeter,

- Structured light mapping system, and

- Infrared spectrometer.

As the deployment device, equipped with characterization and/or sampling end effectors, is inserted into the tank, data will be collected, analyzed, and recorded, and all processes will be controlled from the mobile operations trailer. All functions necessary for in-field, in situ data acquisition, recording, analysis, and reporting will be contained in the trailer. Power supplies, heating, ventilation, air conditioning, and communications subsystems will be integrated as needed to support technology deployment.

This task includes interfacing with the Hanford Tank Waste Remediation System program to define specific characterization needs, functions, and requirements. This task also provides a focal point for coordinating all characterization activities.

\section{TECHNOLOGY NEEDS}

GFX.95-0219

Figure 1.2. Field Support System.

The trailer and equipment will be located in an uncontaminated area up to 900 feet away from the tank. The trailer will support a deployment device, such as a robotic arm, which is placed inside the tank to deploy sensors and cameras. The trailer will provide an operations center for the robot arm, power supplies, video monitors, computers, data
DOE needs tools to characterize the physical, chemical, and radiological properties of tank waste in order to plan for waste retrieval and processing. Tank waste characterization currently involves removing two core samples from each tank, evaluating these samples in a hot cell, and preparing them for detailed analysis. A single core sample can take up to six months to process and costs more than a million dollars. This process needs to be simpli- 
fied and expedited. For safety reasons, the characterization equipment must be operated remotely from an uncontaminated area.

Many of the single shell tanks are known or suspected of leaking. The cause of the leaks is not known in every case. Structural integrity analysis of the tanks is required to identify leaks and ensure that the waste removal activities do not damage tanks. The field support system will ensure that waste analysis and structural integrity data are processed efficiently.

\section{ACCOMPLISHMENTS}

The LDUA has been designed and is currently being fabricated. The support system design has been completed. A trailer is being outfitted for field use. Most of the control and data acquisition systems have also been procured. The trailer instrumentation will be installed and tested in the near future. The LDUA will be completed by the end of FY95.

\section{BENEFITS}

The LDUA and field support system provide an automated, remote system for collection of characterization data. This improves data quality, decreases sample analysis time, and greatly minimizes worker exposure to HLW.

\section{COLLABORATION/TECHNOLOGY}

\section{TRANSFER}

Commercial computer systems have been employed to design the trailer. The control software development has been led by Sandia National Laboratories (SNL), and product commercialization is underway.
For more information, please contact:

Jim Lee

Characterization and Retrieval

Program Manager

Sandia National Laboratories

Richland, WA 99352

(509) 376-7439

Brady R. Davies

Principal Investigator

Sandia National Laboratories

P.O. Box 5800, MS 0952

Albuquerque, NM 87175-0952

(505) $844-5600$

\section{Dennis Olona}

Technical Program Officer

U.S. Department of Energy

Kirtland Air Force Base

Pennsylvania and $\mathrm{H}$ Street

P.O. Box 5400

Albuquerque, NM 87115

(505) 845-6101

TTP Number: AL232001

BIBLIOGRAPHY OF KEY PUBLICATIONS

None at this time. 


\subsection{FIBER-OPTICNEAR-INFRARED SPECTROMETER SYSTEMS}

\section{TASK DESCRIPTION}

Researchers at the Savannah River Technology Center (SRTC) have developed a near-infrared (NIR) spectroscopy system with a fiber-optic probe to measure the moisture content of UST waste. The fiber-optic probe was designed for use in a radioactive environment and will serve as an end effector on the LDUA for in situ measurements in DOE tanks. It can also be used in hot cells, and deployed on a cone penetrometer probe. This technology will allow a radiation-resistant and easy-to-use sensor to rapidly make remote surface moisture measurements in harsh chemical and radioactive environments.

NIR spectroscopy is a well-established technology with many commercially available components and modules. The measurement of water content is difficult because water is normally an infrared interferant with its strong optical absorption bands located around key modular vibrational absorption bands. Water concentration of the tank waste is determined from the optical spectra back-scattered from the waste surface. The moisture-sensing system uses a calibration model, developed with partial least squares fit analysis from standard materials having known moisture content. The spectra from unknown samples are then processed by this mathematical model to produce a water content value.

Researchers must determine the radiation effects on the fiber optic probe. The moisture sensing system must be calibrated, and the effects of different waste material and moisture contents must be evaluated. SRTC has provided hardware and software support for the NIR diode array spectrometers. SRTC has also provided diffuse reflection fiber optic probes for deployment in the hot cells, training to Hanford operators, and minor system software upgrades.

\section{TECHNOLOGY NEEDS}

Ferrocyanides were used to process fission products. Their presence in a tank raises the possibility of an explosion if the moisture within the tank is insufficient. To fully understand the conditions inside these tanks, an in situ method is needed to measure tank waste moisture content.

The present system requires core samples to be removed from the tank, processed through a hot cell, and extensively analyzed. Because each core sample can take up to six months to process, a large backlog exists for characterizing the 332 USTs across the DOE Complex. An easily deployable, in situ method of analyzing safety-related characteristics will help speed the process.

\section{ACCOMPLISHMENTS}

The initial testing of this moisture sensing method with tank simulant materials has been completed. The calibration model was built and tested with four waste tank simulants that are chemically and physically representative of the tank salt cake and slurry mixtures found in Hanford's underground storage tanks. The performance of the NIR moisture sensing correctly predicted moisture within a $+/$ - 5 weight percentage error for all four tank materials. The NIR technique performed even better, $+/-2$ to 3 weight percentage prediction errors, when the samples contained the same chemical constituents. These moisture measurement errors are well within the requirements to establish the safety status of a waste tank containing ferrocyanide materials. Preparations are underway to integrate the NIR and the Raman spectroscopy systems for in situ applications. 
Quantrad Sensor has successfully developed and marketed hand-held, multichannel, alpha, bera, and gamma ray spectrometers for environmental and process monitoring applications.

\section{BENEFITS}

Previously developed NIR spectroscopy systems on this project can be adapted and improved to provide real-time monitoring of waste at DOE sites. A realtime monitoring system will facilitate more efficient processing of a variety of waste types.

A remote NIR hot cell screening probe will streamline the flow of tank materials through the hot cell by reducing the time needed to make moisture measurements. It will also provide the capability to quickly obtain moisture profiles along the axis of the core sample, currently a time-consuming and inaccurate process. An easily deployable in situ NIR system for analyzing safety-related characteristics will help to eliminate the current hot cell backlog. Knowledge of the moisture content is also required for planning of waste retrieval and processing operations.

\section{COLLABORATION/TECHNOLOGY TRANSFER}

NIR technology is reasonably well established. Commercial equipment has been adapted for fiber optic use. Three companies have applied for a license to produce the fiber-optic probe. A CRADA is being negotiated with Ciba-Geigy to test systems in a commercial pesticide plant.

A prototype scanner will be designed and constructed at Lawrence Livermore National Laboratory (LLNL). This scanner will provide preliminary information on potential uses of such scanners as both an NIR humidity scanner for moisture content in cores, and an ultraviolet or laser-induced fluorescence imager for rapid screening of organic core constituents.

The University of South Carolina (USC) is supporting the evaluation of Raman optic probes. USC will analyze the sources of noise in fiber optic Raman probes in support of LLNL's probe design effort.
The University of Idaho is evaluating fundamental probe/materials interactions for NIR information acquisition.

For more information, please contact:

Tom Thomas

Characterization and Retrieval

Program Manager

LITCO

Idaho Falls, ID

(509) 376-7439

Fred R. Reich

Principal Investigator

Westinghouse Hanford Company

P.O. Box 1970

Richland, WA 99352

(509) 376-4063

\section{Roger Christensen}

Technical Program Officer

U.S. Department of Energy

Richland Operations Office

P.O. Box 550

3230 Q Avenue

Richland, WA 99352

(509) 372-4606

TTP Number: RL452001

\section{BIBLIOGRAPHY OF KEY PUBLICATIONS}

P. Jones, CPAC Optical Moisture Monitoring: Investigation of Remote Sensing Scale-Up for Hot Cell and Waste Tank Applications - Task 2B Report, WHC-SD-WM-ER-339, Westinghouse Hanford Company, Richland, WA, July 1994.

F. R. Reich, D. J. Veltkamp, CPAC Moisture Study: Phase 1 Report on the Study of Optical Spectra Calibration for Moisture, WHC-SD-WM-ER-288, Rev. 0, Westinghouse Hanford Company, Richland, WA, November 1993. 


\subsection{FIBER-OPTIC LASER RAMAN SPECTROSCOPIES FOR TANK WASTE CHARACTERIZATION}

\section{TASK DESCRIPTION}

This task develops'and tests fiber-optic Laser Raman spectroscopy systems for characterization of tank wastes. These systems are designed for deployment in both hot cells and in waste tanks, enabling both ex situ and in situ characterization. See Figure $1.4 a$.

For in situ characterization of core sections, LLNL is developing a Raman fiber-optic probe fitted inside a cone penetrometer. Elements used to design and set performance objectives of the Raman probe include the expected tank environment, cone penetrometer requirements, and contaminant concentrations to be measured.

The systems may also be used to chemically profile the waste surface inside a tank. One method of deployment consists of mechanically driving a fi- ber-optic probe to sweep over the surface to be interrogated. The Light Duty Utility Arm (see Section 1.1 ) could be used to precisely position the probe (Remote Fiber-Optic Raman Spectroscopy). Another deployment method would remotely sweep a laser beam within the field-of-view of a spectrometer across the surface. In this case, the simple rotation of a mirror could be used to guide the laser beam and collect the scattered radiation.

Complementing these activities in a system approach are two other subtasks. One is the development of a Raman library/database to support qualitative and quantitative applications of the spectroscopic techniques. The library/database will contain archived Raman spectra that have been obtained from pure material, simulated waste, and real tank waste. See Figure 1.4b. The database will initially hold spectroscopic information on ferrocyanide, ferricyanide, nitrate, and nitrite, but will

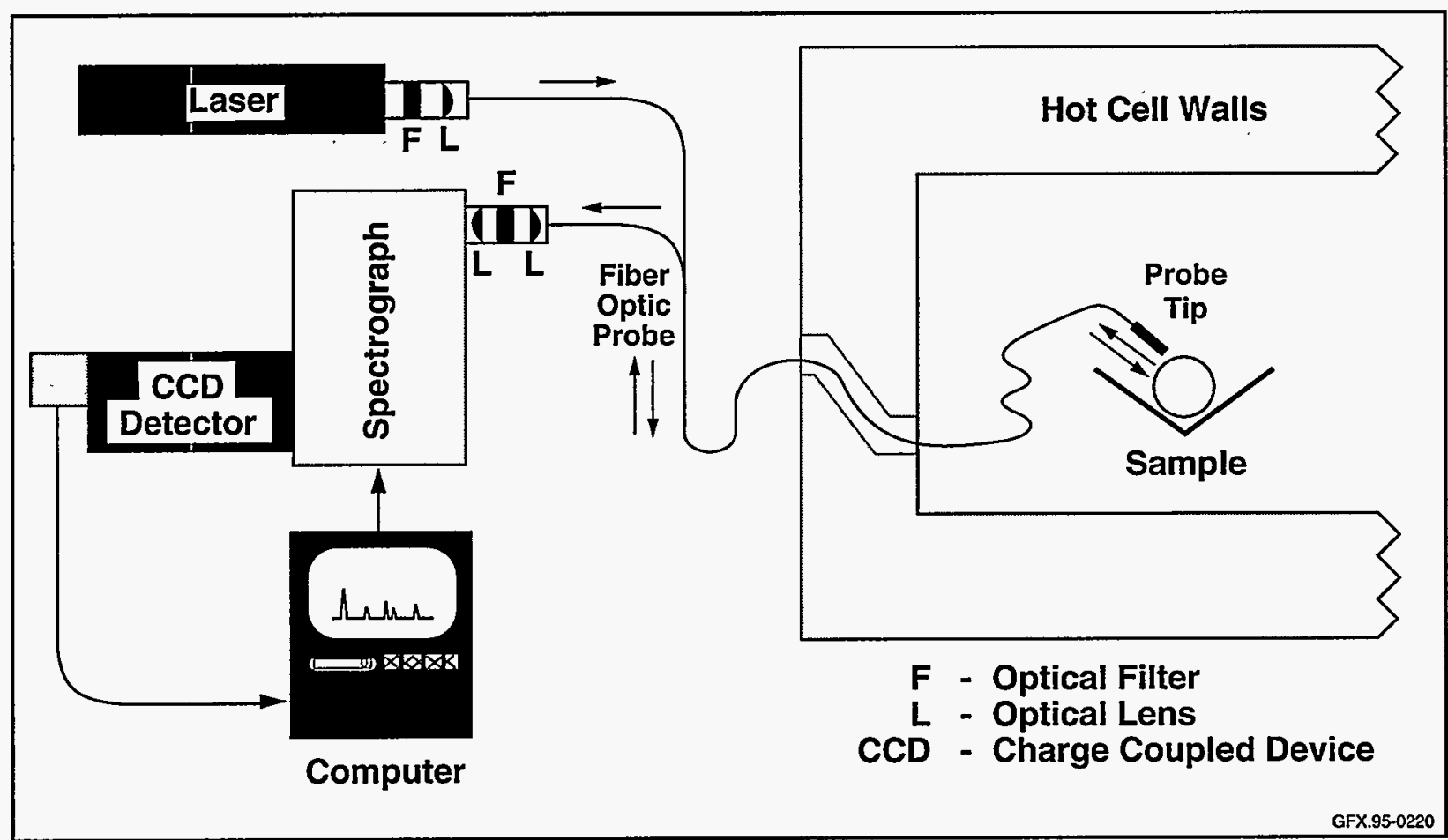

Figure 1.4a. Hot Cell Laser Raman Spectroscopy System. 
be expanded to include other chemical species such as organic compounds. The other subtask is the radiation testing of fiber optics. Two aspects will be addressed in this subtask: survival of optical fiber material in radiation environments, and changes in Raman spectral signal induced by the radiation.

\section{TECHNOLOGY NEEDS}

Laboratory analysis of tank waste is time consuming and expensive. While Raman spectroscopy will not replace established regulatory analysis, its development as a screening technique for ex situ and in situ characterization offers significant reduction in time, cost, and secondary waste generation. It will also minimize radiation exposure of personnel and provide a valuable guide to sampling and analysis of core waste material.

An in situ waste probe will also provide data on the homogeneity, location, and mapping of key waste materials (e.g., ferro/ferricyanide) inside the tanks.

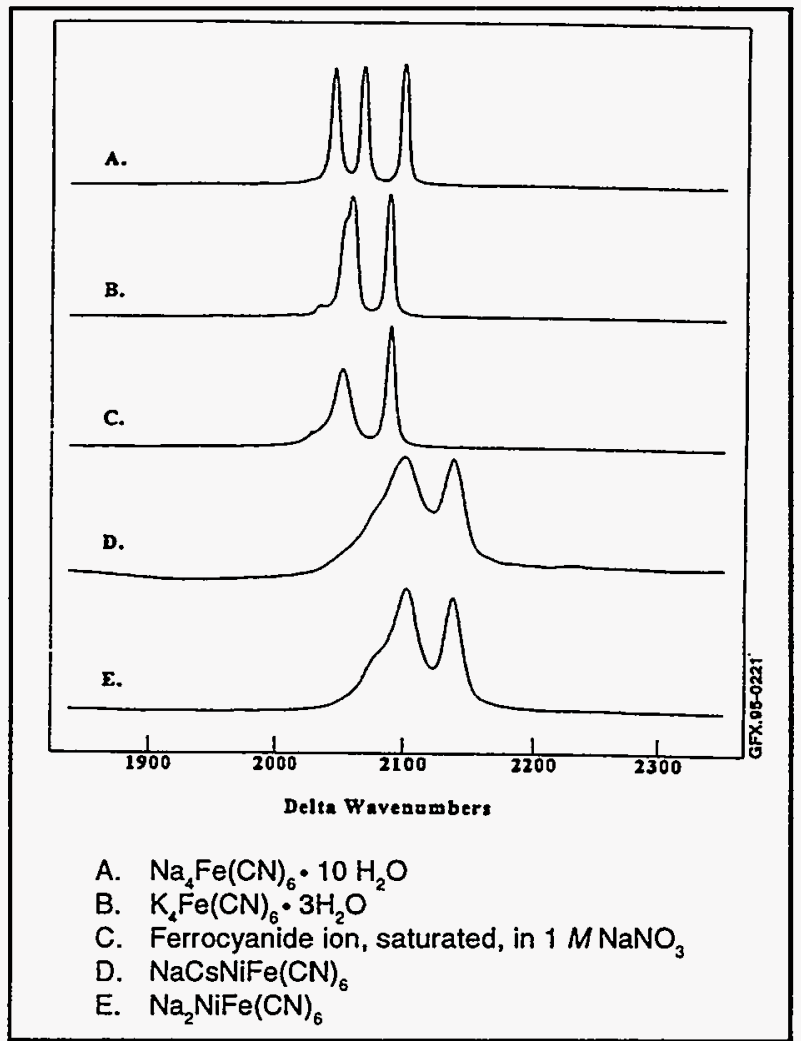

Figure 1.4b. Laser Raman Spectra of Various Nitrate-Containing Materials.
These data are necessary to direct and monitor waste retrieval.

\section{ACCOMPLISHMENTS}

The feasibility of applying laser Raman spectroscopy to tank waste characterization is being demonstrated with cold and hot cell testing. Analyses of pure materials and surrogates show that unique Raman scattering can be used to identify major tank waste components, including ferrocyanide, ferricyanide, nitrates, and nitrites. In addition, a remote fiber-optic probe has been installed in a hot cell at Hanford and is being used to record Raman spectra of real tank waste material.

Two hot cell campaigns provided operational experience and spectral data for five newly arrived tank waste materials, some of which have significant fluorescence. Stable, high-powered laser diodes (785 $\mathrm{nm}$ emission) were ordered as a means to mitigate the fluorescence. A $0.4 \mathrm{Watt}$, high-power doubled NdYAG laser was successfully integrated into the cold Raman test system.

Probe testing was completed with four fiber-optic probe designs, including two commercially available probes. The result indicated that in-line filters effectively reduced silica Raman noise and that probe field-of-view is a strong sensitivity issue with slurry materials.

\section{BENEFITS}

This Raman spectroscopy work provides a basis for a wide range of characterization/sensing systems that will be usable with DOE tank wastes. A hot cell screening system with a Raman and moisture sensor will detect chemical homogeneity along the extruded core axis, to augment the selection of subsamples for detailed chemical analysis. Based on the Raman screening data, it may be possible to reduce the number of sub-samples. This reduction would decrease cost, generate less secondary waste, and significantly enhance the safety of characterization operations. 
This characterization technology will help to objectively identify and quantify chemical risk and hazards, and support remediation activities in a cost effective manner. Future process control applications will allow a more efficient loading of storage matrices for the disposal of low and high level wastes. A Raman system using long optical fiber probes has the potential to be used in restoration or verification of remediation barriers.

\section{COLLABORATION/TECHNOLOGY}

\section{TRANSFER}

Basic support and coordination for the development, integration, and testing of the spectroscopic systems are provided by the Westinghouse Hanford Company (WHC). LLNL has evaluated several spectroscopic deployment methods, including remote fiber-optic and non-contact Raman spectroscopies, and will recommend a conceptual design for a Raman probe suitable for incorporation in a cone penetrometer. SRTC has designed and built Raman probes for hot cell testing.

USC will continue to provide support in the evaluation of Raman optic probes. USC will analyze the sources of noise in fiber-optic Raman probes in support of a probe design effort at LLNL. A prototype cone penetrometer tip that includes a filtered Raman probe will be constructed and tested at LLNL.

A prototype scanner has been designed and constructed at WHC. It is being tested with surrogate core samples. The scanner will enhance hot cell operation by automating routines in with the Raman probe. The end result will be a Raman Scanner that will be delivered to WHC Process Chemistry Laboratory.

The technology support from Florida State University (FSU) and the University of Idaho (UI) will be continued by extending their current technical contracts. FSU is providing support for the application of Raman to Hanford's waste tank materials, and UI is evaluating fundamental probe/materials interactions for Raman information acquisition.
For further information, please contact:

\author{
Tom Thomas \\ Characterization and Retrieval \\ Program Manager \\ LITCO \\ Idaho Falls, ID
}

(509) 376-7439

Fred R. Reich

Principal Investigator

Westinghouse Hanford Company

P.O. Box 1970

Richland, WA 99352

(509) 376-4063

\section{Roger Christensen}

Technical Program Officer

U.S. Department of Energy

Richland Operations Office

P.O. Box 550

3230 Q Avenue

Richland, WA 99352

(509) 372-4606

TTP Number: RL452001

\section{BIBLIOGRAPHY OF KEY PUBLICATIONS}

F.R. Reich, S.J. Mech, S. Saggese, R. Greenwell, T.B. Ilodeau, Evaluation Of Fiber-Optic Sensors For Nuclear Waste Tank Environments, WHC-SA2484-A, Westinghouse Hanford Company. Richland, WA, October 1994.

J.B. Schlenoff Detection and Quantitation Analysis of Ferrocyanide And Ferricyanide, WHC-SD-TDRPT-003, Westinghouse Hanford Company, Richland, WA, February 1993.

F.R. Reich, Environmental Specification for Hanford Deployable Spectroscopy System, WHC-SDTD-FRD-002, Westinghouse Hanford Company, Richland, WA, February 1993. 
T.W. Fischer, Hot Cell Demonstration of Raman Spectroscopy With Hanford Tank Waste, WHCSD-TD-RPT-006, Westinghouse Hanford Company, Richland, WA, January 1993.

M.D. Clements, Environmental Requirements for Hanford Deployable, Cone Penetrometer Raman Spectroscopy Fiber-Optic Probes, WHC-ST-TDRPT-008, Rev.0., Westinghouse Hanford Company, Richland, WA, May 1993 


\subsection{NON-CONTACT IMAGING RAMAN \\ SPECTROSCOPY}

\section{TASK DESCRIPTION}

A non-contact, imaging Raman spectrometry system for rapid chemical screening of underground storage tank wastes is being developed by Lawrence Livermore National Laboratory (LLNL). The basis of this system is an optical field-of-view Raman surface scanner, coupled to an imaging spectrograph with a two-dimensional array detector, that gives spatially resolved, chemical information about the tank waste material. The spatial data will be used to provide a chemical map of the waste surface. See Figure 1.5. Fiber-optics will provide the remote interface between the tank waste environment (e.g., hot cell for core samples, in tank for in situ waste analysis) and external instrumentation. The noncontact imaging scanner optical head design will be compatible with both existing Raman hot cell systems at WHC and commercially available units. The potential of the non-contact imaging system for use with spectroscopies other than Raman is being explored.

\section{TECHNOLOGY NEEDS}

Across the DOE Complex, hundreds of USTs have been used to process and store over 100 million gallons of chemical and mixed chemical/radioactive wastes generated from nuclear weapons and fuels production. Prior to remediation, the wastes inside the tanks must be characterized to identify the chemical and radioactive composition and basic physical parameters. Current techniques of tank waste analysis involve removing solid core samples from the tanks, followed by costly and time consuming wet analytical laboratory testing. Savings in cost and time could be realized in techniques that involve: 1) little or no sample contact, 2) rapid, single pass scanning of chemical constituents, and 3) in siru probes for direct analysis of tank materials in their native environment. Non-contact Raman spectroscopy will address these issues.

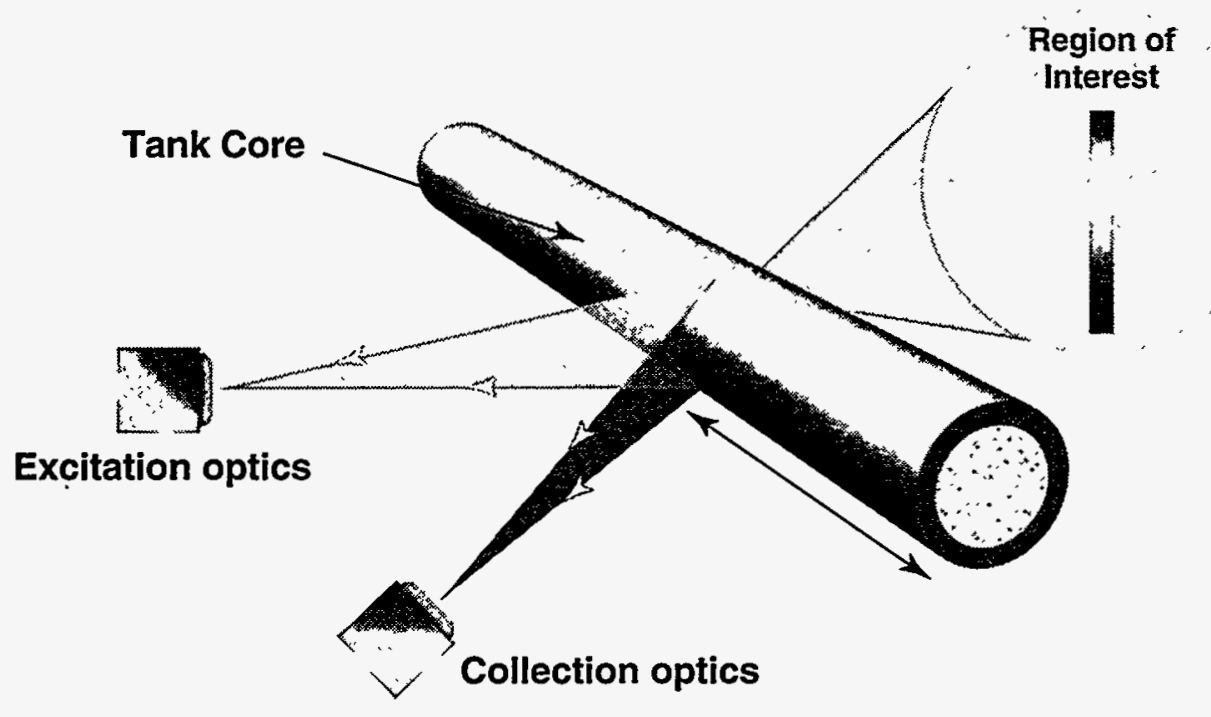

GFX.95-0222

Figure 1.5. Fiber-Optics Provide Remote Interface. 


\section{ACCOMPLISHMENTS}

A prototype, laboratory bench-top model of an imaging Raman core scanner has been constructed and its utility in the chemical characterization of mock core samples has been demonstrated. The ability of the system to characterize the two dimensional surface of a sample has been shown. A comparative study between the single point, contact, fiber-optic Raman probes and the laser scanning, non-contact, imaging Raman spectroscopy has been performed. A report summarizing the results of this study and a point-by-point comparison of the two methods has been issued. Factors considered in the comparative study were: 1) available laser power at the sample, 2) the effect of distance (millimeters) from the fiber probe tip collection optics to the sample surface in the contact case, 3 ) the distance (feet) from the collection optics to the sample surface in the non-contact case, 4) the effect of background lighting, 5) the interference from background Raman scattering, and 6) other method-specific interferences. The detection limit of ferrocyanide was established for each technique. The non-contact method proved to be more sensitive by an order of magnitude ( 0.01 weight percent ferrocyanide).

\section{BENEFITS}

An automated core imaging system will reduce personnel involvement in the costly analysis of tank samples. It is anticipated that the system will produce a surface map (image) of the Raman-active species present on the surface of the core. This information will be used to determine the tank composition and the general heterogeneity of the tank strata. Additional benefits will be provided by the non-contact method, as that approach can eventually be applied to imaging the chemical composition of the entire tank surface. This method may ultimately be used to monitor surface composition during waste recovery processes.

\section{COLLABORATION/TECHNOLOGY TRANSFER}

This project is part of a collaborative effort among researchers at WHC, the Chemistry Department at USC, and SRTC to support characterization for the underground storage tank decontamination program. During FY94, contact was made with LLNL by a commercial vendor. Quantrad Sensor of Santa Clara, California, expressed interest in the prototype laboratory bench-top model of the automated Raman imaging core scanner. This contact will continue during FY95, and could lead to a commercial partnership.

For more information, please contact:

Tom Thomas

Characterization and Retrieval

Program Manager

LITCO

Idaho Falls, ID

(509) 376-7439

Kevin R. Kyle

Principal Investigator

Lawrence Livermore National Laboratory

P.O. Box 808 , MS L-524

Livermore, CA 94550

(510) 423-3693

\section{Richard Scott}

Technical Program Officer

U.S. Department of Energy

Oakland Operations Office

1333 Broadway

Oakland, CA 94612

(510) 637-1623 


\section{TTP Number:}

\section{BIBLIOGRAPHY OF KEY PUBLICATIONS}

K.R. Kyle, Test Report for Remote vs. Contact Raman Spectroscopy, UCRL-ID-1 16643, Lawrence Livermore National Laboratory, Livermore, CA, 1994.

K.R. Kyle, Conceptual Design of a Raman Probe for Inclusion in the In-Tank Cone Penetrometer, UCRL-ID-1 18926, Lawrence Livermore National Laboratory, Livermore, CA, 1994.

K.R. Kyle and E.L. Mayes, Review of Sensors for the In Situ Chemical Characterization of the Hanford Underground Storage Tanks, UCRL-ID118561, Lawrence Livermore National Laboratory, Livermore, CA, 1994. 


\subsection{LASER RANGE FINDER AND STRUCTURED LIGHT MAPPING SYSTEMS}

\section{TASK DESCRIPTION}

ORNL and PNL are developing laser based systems to characterize the inside of waste storage tanks. The PNL system, a Laser Range Finder (LRF), will be designed to take advantage of the LDUA as a platform for the hardware. The ORNL system is a self-deployed,Structured Light Mapping System that may also be used with the LDUA.

These technologies are well established and based on relatively simple concepts. The hardware consists of a laser and a receiver (such as a camera) and data processing equipment. For the Structured Light System, the position and direction of propagation of the laser beam is known and controlled. The camera shows the two dimensional projected position of the beam on the surface to be mapped. Knowing that this position is the intersection of the laser beam with the object, one can perform simple trigonometric calculations to determine the position of the point in space. The Laser Range Finder uses a laser to measure line of sight distance to an object. Given the distance to this object in a known (controlled) direction, its position in space is easily calculated. In each of these cases, a three dimensional image of the object and its position can be determined from the measurement of multiple points. See Figure 1.6a.

The Structured Light Surface Mapping System can be deployed through either single or multiple risers. See Figure 1.6b. For multiple riser deployment, the laser and the camera are inserted in separate risers, giving a very accurate and efficient "pitch and catch" set-up. See Figure 1.6c.

For cases where it may be necessary to deploy the entire system through a single penetration, the system will be capable of being deployed through a single 4 inch riser, although there will be some loss of accuracy and detail.

The Laser Range Finder is based on an existing piece of commercial hardware and appears to be well suited for use in tanks. Data fusion capability is being developed to combine data from the LRF and Structured Light to provide an integrated three dimensional view (world map), which will aid in path planning and collision avoidance. Each of these systems will be radiation-hardened to allow for longer in-tank time and, therefore, higher resolution. Software is also being developed to aid in data acquisition and control.

\section{TECHNOLOGY NEEDS}

A mapping system is needed for planning and carrying out waste retrieval operations. These systems will provide topographical data to the controller regarding obstacles and waste topography. This reduces the risk of damage to the retrieval and deployment equipment, to the hardware within the tank, and to the tank itself.

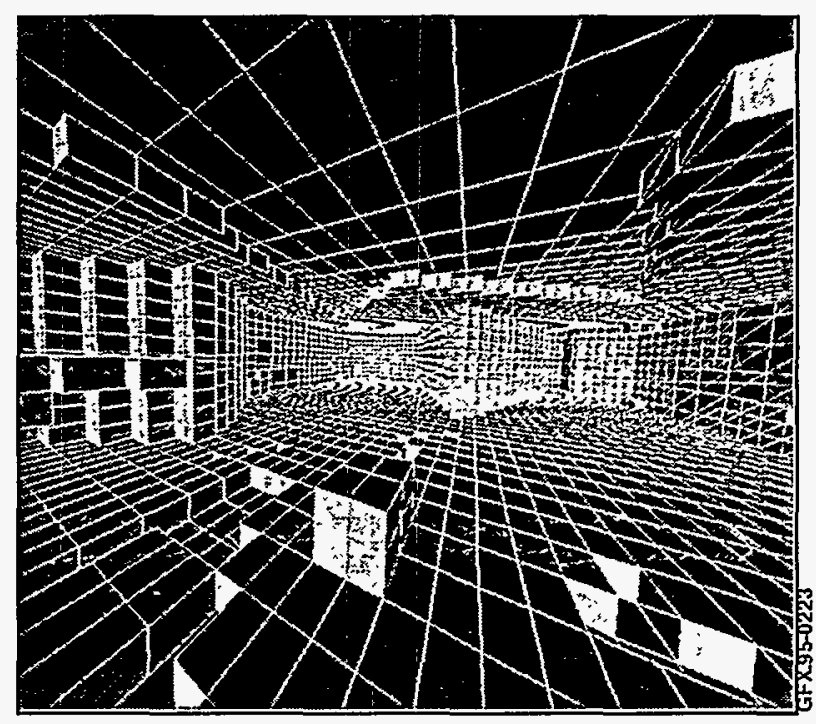

Figure 1.6a. World View After First Rough Cut By Laser Range Finder. 


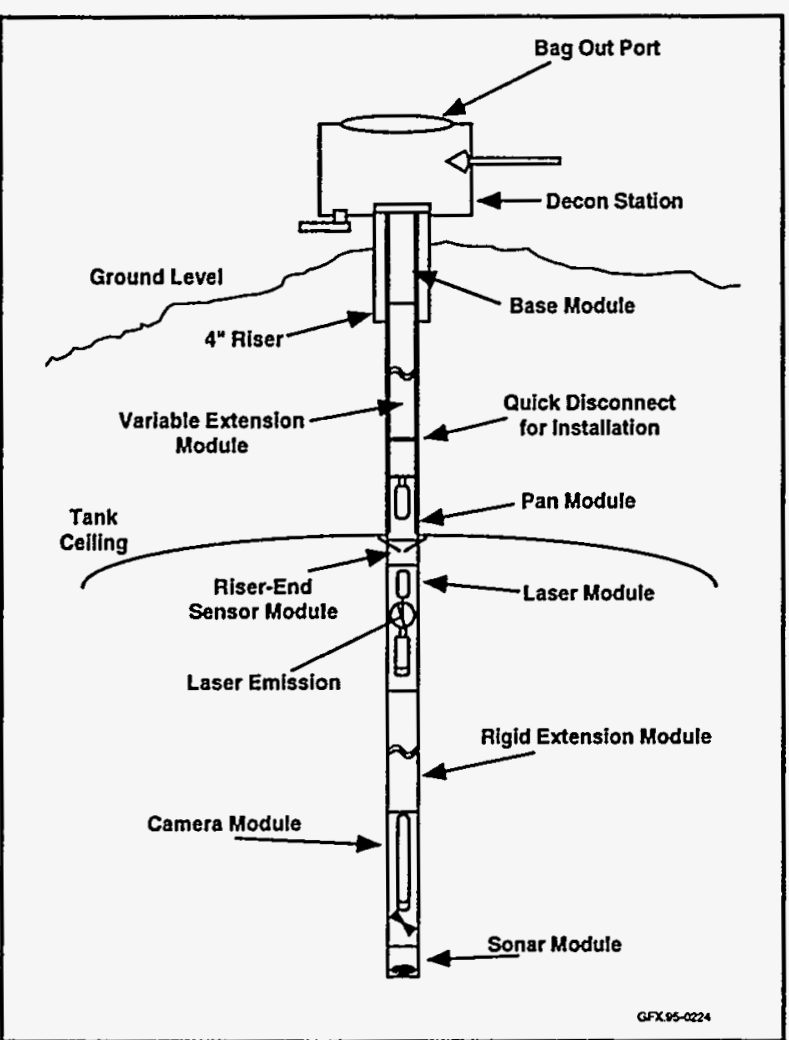

Figure 1.6b. LDUA Structured Light Surface Mapping Conceptual Design for Sensor Probe.

\section{ACCOMPLISHMENTS}

In 1992, a surface mapping system based on the structured light approach was deployed at Fernald to map waste surfaces in the K- 65 silos. The system contributed significantly to the successful completion of a CERCLA Removal Action Milestone in December 1993. The successful field deployment of structured light technology at Fernald made it highly desirable to both commercialize the technology and transfer it to the Hanford site.

\section{BENEFITS}

These systems enable the creation of a three dimensional map (world model) inside the tank, including the waste surface shape, contour, and volumetric data. They will also assist in the planning and execution of waste characterization and retrieval operations.

The PNL LRF System is based on the laser-scanning laser-range finder manufactured by Perceptron. The Laser Range Finder has lower resolution than the Struc- tured Light System, but is capable of providing near real time images. These capabilities qualify it for use in supervisory. control and/or periodic surveillance. The structured light approach is slower, but gives a much finer resolution in all three dimensions. The Structured Light System has demonstrated field performance of accuracy and repeatability of better than 0.5 inches. It may be used to map the interior of the tank, including: the surface contour, the condition of the walls and dome, and the location of in-tank hardware.

\section{COLLABORATION/TECHNOLOGY TRANSFER}

Mechanical Technology Incorporated (MTI) has entered into two CRADAs with SNL and ORNL to develop a second generation surface mapping system suitable for deployment in the tanks at Hanford. These CRADAs will allow technology transfer of the Fernald mapping system and any new technologies developed within the CRADA.

For more information, please contact:

Tom Thomas

Characterization and Retrieval

Program Manager

LITCO

Idaho Falls, ID

(509) 376-7439

Barry L. Burks

Principal Investigator

Oak Ridge National Laboratory

P.O. Box 2008

Oak Ridge, TN 37831-6273

Johnny O. Moore

Technical Program Officer

U.S. Department of Energy

Oak Ridge Field Office

P.O. Box 2001

Oak Ridge, TN 37831-8620

(615) 576-3536 


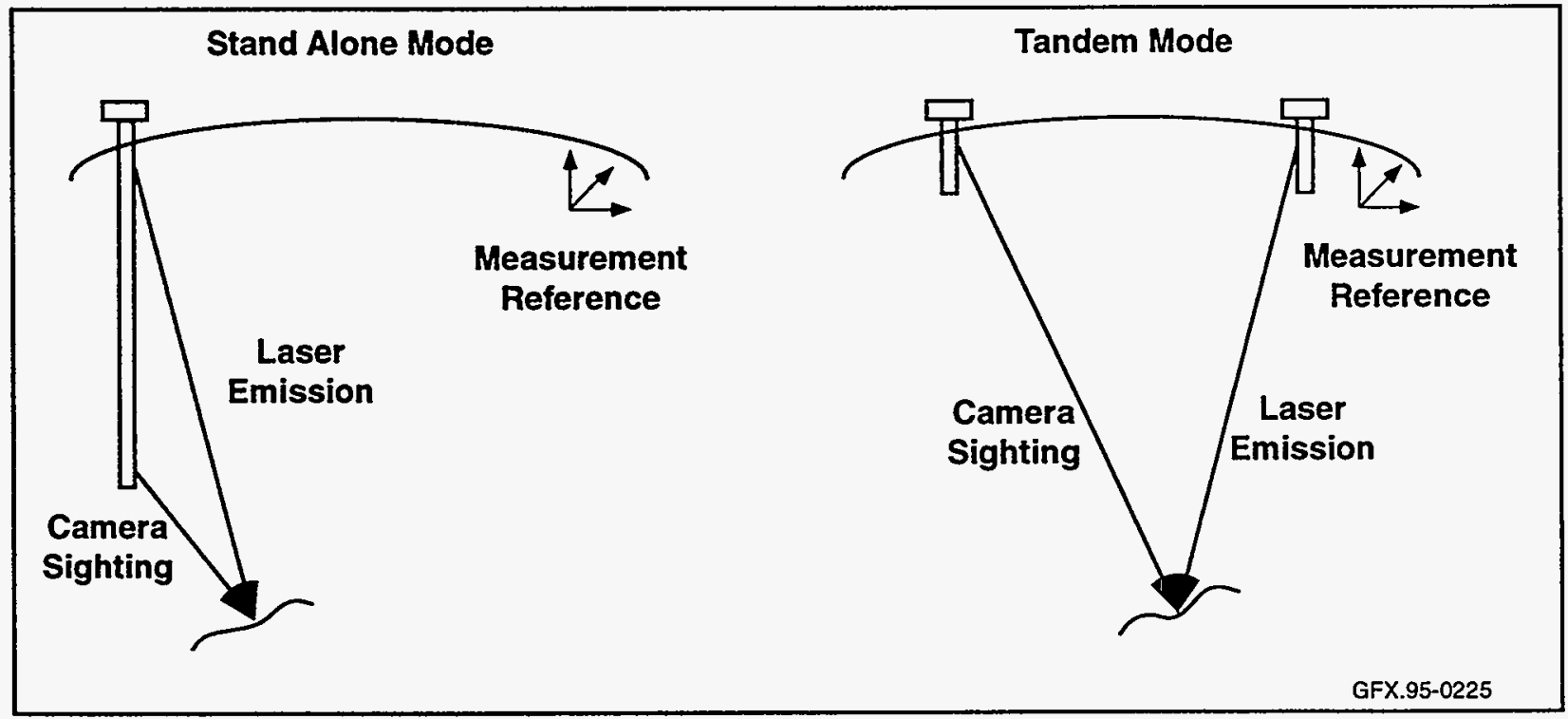

Figure 1.6c. LDUA Structured Light Surface Mapping Sensor Probe Operation.

TTP Number: OR132001

BIBLIOGRAPHY OF KEY PUBLICATIONS

None at this time. 


\subsection{PHYSICAL PROPERTIES END-EFFECTOR FOR LIGHT DUTY UTILITY ARM}

\section{TASK DESCRIPTION}

Weapons production by-products stored in USTs are one focus of DOE's remediation challenge. Remediation will require that the contents of the tanks be rendered benign or stable for long term storage. The strategies and design of waste dislodging and removal will require detailed knowledge of the waste's physical properties and its distribution within the tank.

Measuring the mechanical properties of the wastes within the tanks requires that the characterization system be operated in the waste tank's environment, be deployable as an end effector on the LDUA, be maintainable in the field, and be capable of measuring the needed parameters to the required resolution and accuracy. Therefore, the challenge of in situ physical property measurements includes subtasks to provide identification and prioritization of physical property needs, and qualification, deployment, maintenance, and compatibility of the systems and functions.

This activity will use the best commercially available technology. In the areas where available technologies do not meet the needs, emerging technologies will be considered. The task includes development, testing, and deployment of sensors and systems in the hot cell, directly into the tank, and, in the case of leak detection, in the proximity of the tank.

A major focus of this activity is to support the design of waste dislodging and conveyance equipment to handle existing wastes.

\section{TECHNOLOGY NEEDS}

Sensors to measure physical properties of tank waste are needed for the design and operation of retrieval equipment.

\section{BENEFITS}

This activity reduces time and costs by maximizing the use of the best available technology to:

- Provide a qualified method and equipment to measure mechanical properties of tank waste in situ, and

- Provide information on the abilities and limitations of methods and/or services for detecting tank leaks into the vadose zone.

\section{ACCOMPLISHMENTS}

The functions and requirements of the system have been prepared, the technology/vendor and literature searches have been completed, and the preparation of functional specification initiated.

Researchers have identified the physical parameters that are needed to design the waste retrieval equipment. The priorities for obtaining the physical parameter data were determined based on the importance of each parameter in the design of retrieval equipment.

Candidate technologies identified from existing methods and devices include:

- Standard penetration test for comprehensive strength, density, and shear strength;

- Quasi-static penetration tests for comprehensive strength, density, and shear strength;

- Buoyancy probe for density;

- Shear vane for shear strength and viscosity; and

- Pressure meter for shear strength.

The functions and requirements for all LDUA end effectors were defined in subsections within the main LDUA functions and requirements docu- 
ment. LLNL has demonstrated its Electrical Resistance Tomography (ERT) method of leak detection at the Hanford leak detection test site.

Westech and Rimtech, two private companies, demonstrated their on-site volumetric imaging capabilities at the leak detection test site.

\section{COLLABORATION/TECHNOLOGY} TRANSFER

This activity uses the best available technology from the industrial and federal sources. Where available technologies do not meet the need, emerging technologies will be considered. The teaming and collaborations include Texas Tech University, Rimtech, and Westech. It is possible that MIT and Elohi will be added to the team. Texas Tech University is assessing the feasibility of applying an existing technology to optically monitor material viscosity and shear stresses, on-line or in situ. Two commercial companies, Rimtech and Westech, provide leak detection services of those technologies that had performances assessed at the leak detection test site. Acoustic imaging of the USTs has been demonstrated by a team of geoscientists from MIT's Earth Resources Laboratory, Elohi's commercial geophysics acoustic services, and LANL.

For further information, please contact:

\section{Tom Thomas}

Characterization and Retrieval

Program Manager

LITCO

Idaho Falls, ID

(509) 376-7439
Steve J. Mech

Principal Investigator

Westinghouse Hanford Company

P.O. Box 1970

Richland, WA 99352

(509) 376-8858

\section{Roger Christensen}

Technical Program Officer

U.S. Department of Energy

Richland Operations Office

P.O. Box 550

3230 Q Avenue

Richland, WA 99352

(509) 372-4606

TTP Number: RL421211

\section{BIBLIOGRAPHY OF KEY PUBLICATIONS}

Underground Storage Tank Integrated Demonstration and the Electric Leak Detection System (ELDS), WESTEC Project 94128, Westinghouse Hanford Company, Richland, WA, September 1994.

TWRS Integrated Technology Plan, DOE/RL-9261, Rev. 1, Westinghouse Hanford Company, Richland, WA, June 1994.

Q.H. Nguyen, Summary of Tank Waste Physical Properties at the Hanford Site, WHC-EP-0756, Westinghouse Hanford Company, Richland, WA, April 1994.

W.A. McCormick, Tank Waste Physical Properties Prioritization Procedures and Results, WHC-SDTD-RPT-009, Westinghouse Hanford Company, Richland, WA, April 1994.

Functions and Requirements for the Light Duty Utility Arm Integrated System, WHC-SD-TDFRD-003, Westinghouse Hanford Company, Richland, WA. 


\section{TASK DESCRIPTION}

Together with a consortium of government agencies, TFA is developing and testing an acoustic emission method to locate leaks from underground single- and double-contained piping systems carrying hazardous and radioactive wastes. This system will be deployed in facilities across the DOE Complex to locate and detect leaks.

Leaks in underground pipeline systems can be located using the characteristic sound waves generated by the flow of fluids (either liquids or gases) through a hole (leak). The difference in primary or secondary line pressure and the environment causes flow into the secondary line or the environment, depending upon the location of the leak. Sound- sensitive sensors placed along the entire length of the pipeline transform sound (mechanical) energy from the leak to electrical energy. A signal analyzer evaluates these electrical impulses to determine the distance of the signal source from a known reference point. See Figure 1.8.

ORNL will participate in the development of an electronic detection/location system that can be employed with any existing leak detection system to provide a highly reliable, intrinsically safe, and cost effective method to locate leaks.

The actual development of the signal processing/ evaluation software and analysis of existing hardware systems and techniques is being performed at the U.S. Environmental Protection Agency's (EPA's) Risk Reduction Test Facility in Edison, NJ. The

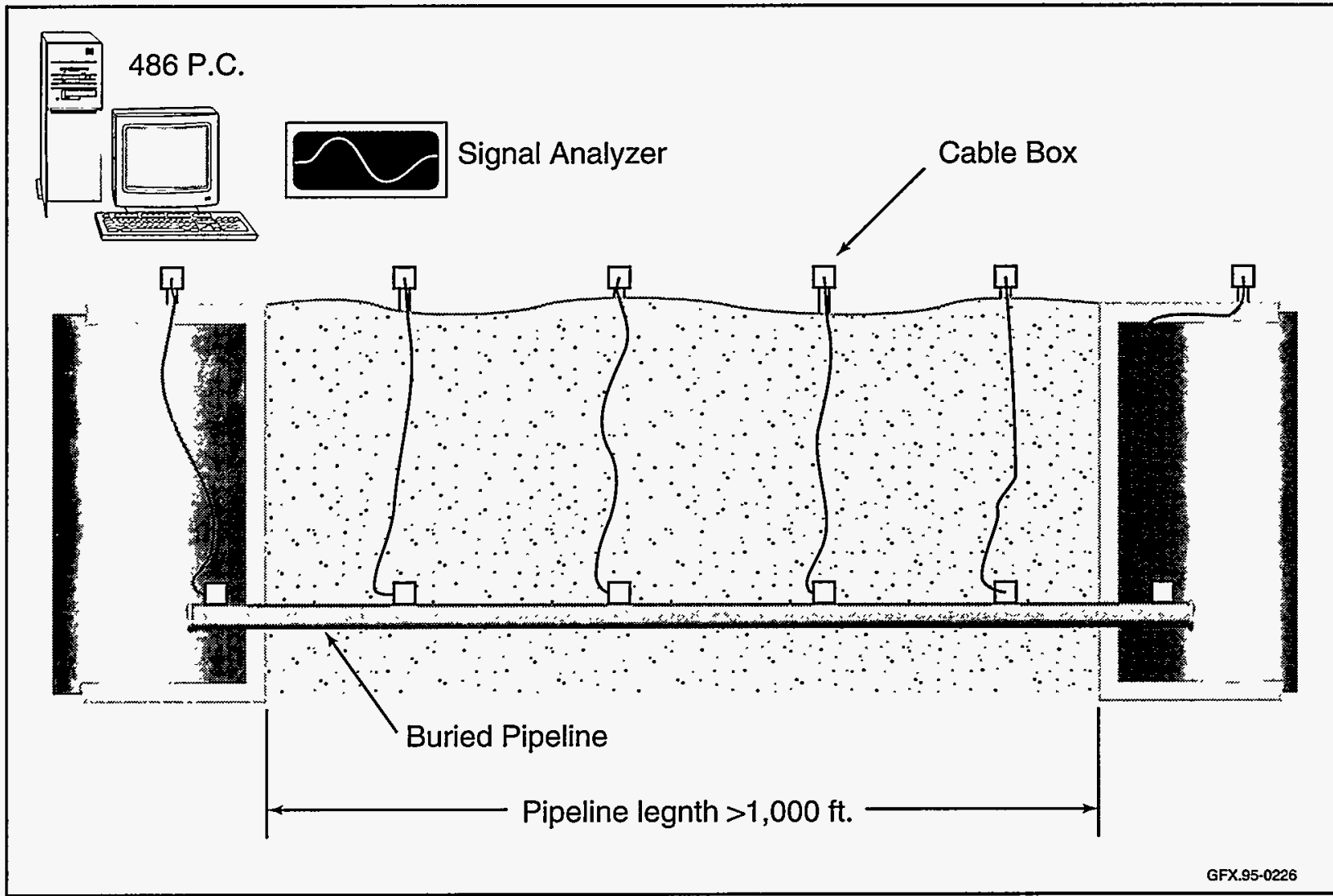

Figure 1.8. Acoustic Emission Figure. 
program management responsibilities of this activity rests with the National Science Foundation (NSF), and a committee comprised of technical consortium representatives from DOE, EPA, DoD, Navy, Army Corps of Engineers, U.S. Department of Transportation (DOT), and the Strategic Environmental Research and Development Program (SERDP).

\section{TECHNOLOGY NEEDS}

The public has become increasingly aware of existing and potential environmental damage from leaks in underground and aboveground storage tanks and piping systems. Over 250,000 releases from USTs and pipelines have been confirmed to date, and EPA estimates that as many as 15 to 20 percent of the approximately 1.8 million regulated USTs and piping systems in the United States are now leaking or can be expected to develop leaks in the near future. In addition, there are over 750,000 aboveground storage facilities with similar problems.

Existing federal regulations (40 CFR 280 and 281, September 1988) require testing of underground tanks and pressurized pipelines containing petroleum products and other hazardous materials on a regular basis. Once leaks are detected, they must be corrected. While this requirement appears relatively simple, the technologies currently available for monitoring the operation of aboveground and underground tanks and piping systems are only marginally effective and unable to give an indication of leak location. An in situ method is needed to detect and identify the location of fluids escaping confinement under pressure. This is especially important for pipelines transporting high level radioactive waste. As part of the remediation of DOE's USTs, the waste will be transported from USTs to processing locations in double walled pipes separated by an annulus.

\section{ACCOMPLISHMENTS}

A consortium composed of NSF, DOE, EPA, DoD, Navy, Army Corps of Engineers, DOT, and SERDP has been assembled to fund and manage the work so that it is beneficial to all parties.

Various types of acoustic sensors, intended for use in the proposed system, have been tested to determine their anticipated life expectancy when subjected to radiation fields. This established a service life cycle for sensors attached to radioactive waste piping. A project plan has been developed to establish the project schedule, assign areas of responsibility, and validate the project's estimated cost. Several consortium management committee meetings have been held to review project documents and preliminary activities at the Edison, NJ, facility.

\section{BENEFITS}

The Acoustic Emission Method for detection of pipeline leaks will rapidly and accurately (plus or minus 24 inches in 200 feet) locate leaks so they can be excavated with a minimum of waste generation, hazard to personnel, and system down-time. Other agencies see this system as valuable to limiting spills into the environment from variery of services, most notably aircraft and motor fuels.

In addition to providing indications of smaller leaks than can now be detected, the leak location capability will provide precise information for repair of defective underground systems. This capability will mean less soil excavated to repair leaks, less exposure of personnel to radioactive and hazardous contamination, less waste generated when a pipe fails, less down time for essential waste transfer systems, reduced releases to the environment, and more effective compliance with regulatory requirements for underground tank and piping systems.

\section{COLLABORATION/TECHNOLOGY TRANSFER}

This work is being led by the NSF. ORNL has been involved in Nondestructive Test Development.

The pipeline leak project is an interagency cooperation and is partnering with the private sector to 
develop a system or product with immediate transfer value to the private sector.

The system will be developed at the EPA Center for Risk Reduction at Edison, NJ. The field test will be conducted at various DOE, DoD, and non-governmental sites (e.g., Exxon, New York Port Authority, etc.) to demonstrate the actual operational capabilities and limitations of the system under other than controlled conditions and situations.

Iowa State University (ISU) and the New Jersey Institute of Technology (NJIT) will complete benchscale studies of limit of detectability and reproducibility for double-contained piping systems, and large scale single-contained transfer piping.

For more information, please contact:

\section{Tom Thomas}

Characterization and Retrieval

Program Manager

LITCO

Idaho Falls, ID

(509) 376-7439

\section{Cal E. Pepper}

Principal Investigator

Oak Ridge National Laboratory

Martin Marietta Energy Systems

P.O. Box 2007

Oak Ridge, TN 37831-6046

(615) 574-6940

Johnny O. Moore

Technical Program Officer

U.S. Department of Energy

Oak Ridge Operations Office

P.O. Box 2001

Oak Ridge, TN 37831-8621

(615) 576-3536
TTP Number: OR152001

BIBLIOGRAPHY OF KEY PUBLICATIONS

None at this time. 


\section{WASTE DISLODGING AND CONVEYANCE}

\section{Section 2.0}


The 332 USTs across the DOE Complex have received a diverse accumulation of wastes during the past 50 years of weapons production. Recently, as the tank conditions have deteriorated and the risk of leakage increased, de-watering processes have been used to remove much of the free liquid. The tanks now contain wastes ranging in consistency from remaining supernate (liquid) and soft sludges to concrete-like salt cake. Tanks also contain miscellaneous foreign objects and in-tank hardware such as piping. Unlimited sluicing, which consists of adding large quantities of water to suspend solids, is the baseline DOE method for sludge removal from tanks. This process is not capable of removing all of the material from tanks. Its use has been questioned by the State of Washington, due to existing and potential leaks of hazardous and radioactive liquids from corroded and deteriorated tanks into nearby soils and ground water.

The Waste Dislodging and Conveyance (WD\&C) task of the Tank Focus Area is developing tools for the removing materials from these tanks. These devices include suction devices, rubblizing devices, water and air jets, waste conditioning devices, grit blasting devices, transport and conveyance devices, cutting and extraction tools, monitoring devices, and various mechanical devices for recovery or repair of waste dislodging and conveyance tools. For some retrieval operations it may be necessary to add small amounts of water to facilitate waste dislodging and removal. However, systems are being optimized to minimize the amount of water added to tanks and to position the conveyance equipment deployed with the dislodging hardware to remove solid waste and free liquid promptly.

Dislodging and conveyance tools will ultimately be deployed as end effectors on a remotely operated, articulated Long Reach Arm being developed by OTD's Robotics Program. They will need to be capable of performing in a radiation environment of up to $10,000 \mathrm{rad} / \mathrm{h}$ and withstanding an accumulated dose of $107 \mathrm{rad}$. 


\section{$2.1 \quad$ HIGH/MEDIUM PRESSURE WATER JET END EFFECTORS}

\section{TASK DESCRIPTION}

The primary objective of the WD\&C activities funded by the TFA is to develop the processes and technologies necessary for rubblizing and removing waste from DOE USTs.

Technologies under development include tools that use water jet technology to dislodge the waste while simultaneously conveying the waste and the used water to the surface by using pneumatic or air conveyance systems. Past Practice Sluicing introduced large amounts of water into the USTs, while the WD\&C dislodging tools limit water use rate with high energy, high pressure water jets. Simultaneous suction removes the waste and water and prevents leaking of tank waste into the surrounding soils and ground water. See Figure 2.1.

Currently, there are two tools under development. The scarifier uses ultra-high-pressure water jets $(40,000$ to $50,000 \mathrm{psi})$ in a dislodging tool with a pneumatic transport system. The miner uses medium pressure water jets $(5,000$ to $11,000 \mathrm{psi})$ with jet pump transport.

Other objectives of these tasks include developing mining strategies for the dislodging/conveyance system and developing a fundamental understanding of the mechanics of dislodging and mobilizing waste using the miner/jet pump system and the scarifier/pneumatic transport system. The performance of these systems will be investigated in experiments to develop parametric data for further system design and for integrated testing.

\section{TECHNOLOGY NEEDS}

There are many problems and challenges associated with the removal of waste from USTs. Most tanks contain multiple waste forms, ranging from sludge and supernate to heel and saltcake. Some waste

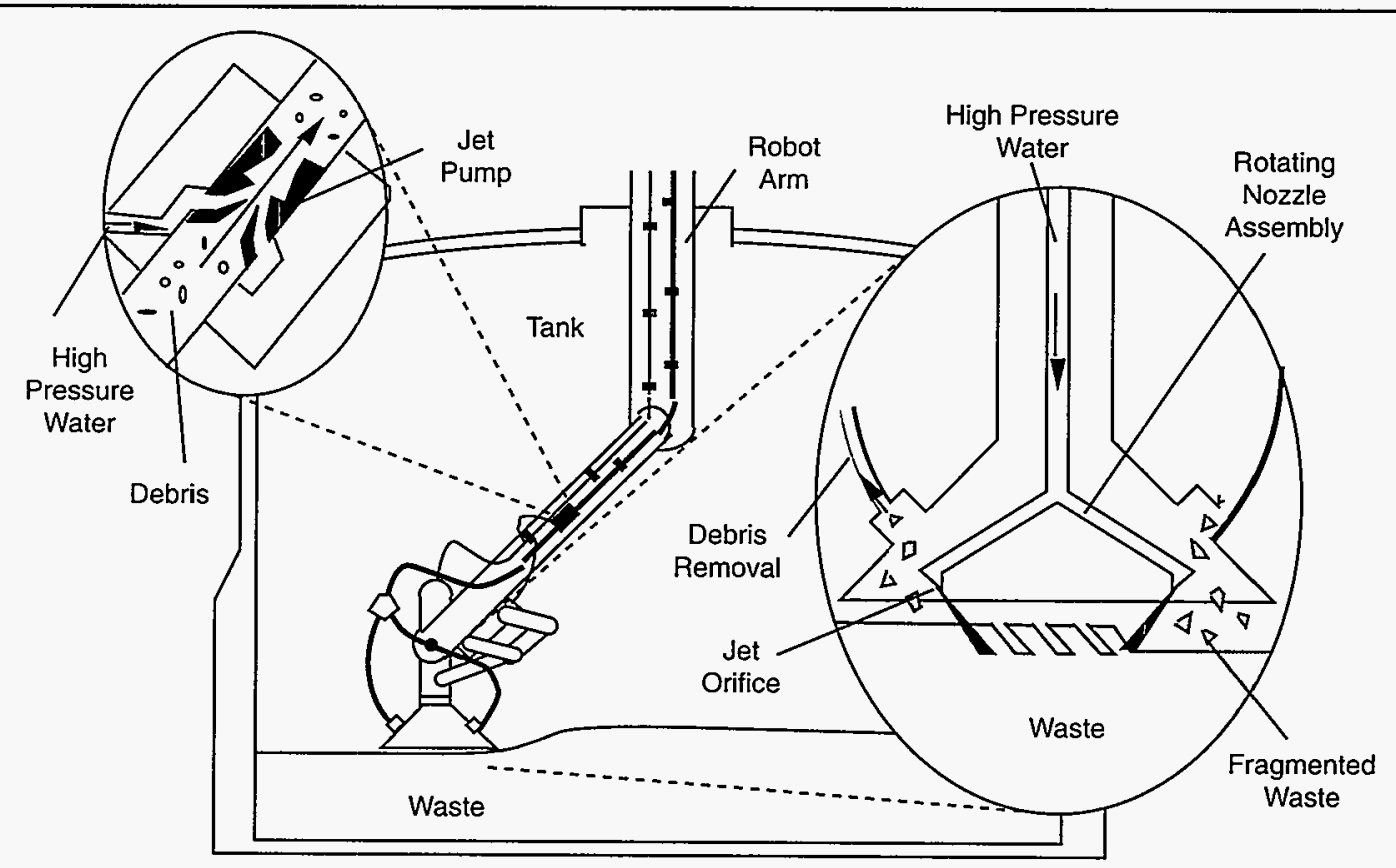

GFX.95-0247

Figure 2.1. Water Jet Cutting. 
forms are as hard as concrete. Structural integrity of tanks is a concern. Many have exceeded their design life, and corrosion has significantly increased their degradation. Some are known to be leaking, and others are suspected of leaking. Any further stresses on the tanks themselves should be avoided.

The baseline retrieval technology of sluicing uses large quantities of water to suspend solids to remove them from the tank. Introducing large amounts of water into a leaking tank can cause extensive environmental contamination.

An additional concern is that the waste needs to be removed in a form compatible with subsequent waste processing and disposal systems. While an evaporator could be used to remove excess water, the addition of this processing step may be unnecessary and inefficient.

\section{ACCOMPLISHMENTS}

The WD\&C waterjet technologies have been used to meet Hanford Triparty Agreement milestones M-06-02: "Waste Retrieval Testing in Scale Model Tank" and M-45-01: "Develop SST Rerrieval Technology". The program has demonstrated a halfscale high-pressure scarifier waste removal rate of 2 $\mathrm{ft}^{3} / \mathrm{min}$., half the target full-scale retrieval rate of 4 $\mathrm{ft}^{3} / \mathrm{min}$. Also, an Integrated Hydraulics Testbed has been assembled at Hanford and is being used to demonstrate the WD\&C system.

\section{BENEFITS}

The WD\&C effort of the Tank Focus Area is focused on retrieving waste from USTs with minimum production of waste and environmental impact. A manipulator will be used to position tools in a tank to dislodge the waste, while a conveyance system removes the dislodged waste. The baseline method of sluicing introduces large amounts of water into the USTs, while the WD\&C dislodging tools limit water use with high energy, high pressure water jets. Water loss is further limited with concurrent suction to remove the waste and water, which are then conveyed pneumatically away from the surface. Immediate removal of water eliminates the chance of increasing releases from leaking tanks. No additional stress (static or dynamic) is put on structurally marginal tanks, thereby preventing potential failure of containment. In addition, secondary waste production will be reduced with working fluid retrieval and recycling of greater than 98 percent single pass efficiency.

The high-pressure scarifiers provide an enabling technology for some hard pan and saltcake wastes, which sluicing would not be able to remove. Furthermore, these tools will aid in meeting the 99 percent retrieval minimum mandated by the Hanford Tri-Party Agreement between DOE, EPA, and the State of Washington Department of Ecology.

\section{COLLABORATION/TECHNOLOGY TRANSFER}

This technology is an adaptation of existing systems for cleaning and cutting materials. Many modifications, however, are required to meet the performance parameters so the equipment can work effectively within the restricted conditions encountered in the USTs. The weight of the dislodging and conveyance end effector must bekept to a minimum for the deployment tool to maintain control and accuracy of the scarifier ( $\leq 200 \mathrm{lbs}$.). The highpressure jet scarifier is being developed by Quest Integrated of Kent, Washington. Dr. David Summers of the University of Missouri-Rolla and Dr. Clayton T. Crowe of Washington State University are developing the medium pressure water jet mining end effector, and are collaborating in designing and testing the dislodgers and conveyance systems. 
TTP Number: RL332003

For more information, please contact:

\section{BIBLIOGRAPHY OF KEY PUBLICATIONS}

Jim Lee

Characterization and Retrieval

Program Manager

Sandia National Laboratories

P.O. Box 1970, MS NI-21

Richland, WA 99352

(509) 376-7439

\section{Michael W. Rinker}

Principal Investigator

Battelle Pacific Northwest Laboratory

Richland, WA 99352

\section{Roger Christensen}

Rinker, M.W., O.D. Mullen, and B.K. Hatchell, Waste Dislodging and Conveyance Testing Summary and Conclusions to Date, PNL-10095, Pacific Northwest Laboratory, Richland, WA, 1994.

Summers, D.A., Hazardous Waste Dislodging and Conveyance: The Confined Sluicing Method, PNL10074, Pacific Northwest Laboratory, Richland, WA, 1994.

Quest Integrated, Inc., Waterjet and Airjet Scarifier Testing for Removal and Decontamination of Radioactive and Hazardous Waste, TR-511/11-90. Kent, WA, 1990.

Technical Program Officer

U.S. Department of Energy

Richland Operations Office

P.O. Box 550

$3230 \mathrm{Q}$ Avenue

Richland, WA 99352

(509) 372-4606 


\subsection{MECHANICS AND HYDRAULICS TEST BED}

\section{TASK DESCRIPTION}

The primary objective of the WD\&C activities is to support the development of baseline dislodging and conveyance technologies for the retrieval of waste inside Hanford Single Shell Tanks. The Mechanics task is one facet of WD\&C development. Its mission is to understand the physics of the processes for waste dislodging and conveyancs, medium and highpressure waterjet dislodging and three-phase flow transport.

This physical understanding provides guidance for development of specifications for systems that:

- Retrieve varied waste forms,

- Operate continuously and efficiently,

- Minimize impact to the long reach arm,

- Are easily maintained, and

- Conform to ALARA.

A variety of candidate technologies have been screened and narrowed to waterjet pumping or pneumatic conveyance for retrieval. Preliminary testing has demonstrated the viability of these technologies, with indications that high-pressure waterjet dislodging coupled with air conveyance may be the most robust and effective combination.

The development approach for the mechanics task is three tiered:

- Conduct experiments and define the physics of waste capture and transport,

- Develop a model to understand scaling relationships between physical parameters, and predict operation for alternate configurations, and

- Conduct integrated experiments to investigate mining strategies for effective system deployment, and to confirm full-scale retrieval rates.
The Mechanics task aims to understand and predict the physics of three-phase transport. The three phases in retrieval systems are: 1) solids, waste simulants for salt cake and sludge, 2) liquid, scarifier cutting fluid and lubrication, and 3) transport medium, which may be air or water.

The tests are designed to evaluate the blower power required to provide transport as a function of solids loading and air flow for a variety of waste simulants and piping configurations. Simulants for wastes include:

- Particulate - sand, gravel, and coarse-ground salt cake to simulate material dislodged by scarifier,

- Sludge - kaolin clay based,

- Viscous liquid - kaolin clay slurry, and

- Lubricant - water.

Piping configurations vary these parameters:

- Diameter,

- Orientation - vertical, horizontal, inclined, and

- Components - flexible lines, linkages, and elbows.

The Hydraulic Testbed (HTB) program will involve all segments of WD\&C to apply knowledge gained through parametric testing. The HTB program will also collaborate closely with Hanford Tank Waste Remediation Systems (TWRS) Robotics on deployment and control issues. See Figure 2.2 .

The test program for the HTB will characterize aspects of waste dislodging and conveyance processes, evaluate process equipment performance, and address integration issues associated with deploying WD\&C-based systems by a manipulator arm. 
The HTB Test Program will investigate WD\&C system deployment strategies to determine appropriate mining strategies, system dynamics, level of control, and sensor requirements. The HTB supports:

- Longer duration, multiple-pass tests on large waste simulant fields,

- Three-dimensional deployment typical of a mining operation, and

- Modeling of the behavior and response of various deployment/control systems.

Cold testing of prototype end effectors, study of offnormal events and failure-recovery, operations research, and operator training for in-tank hardware are viable long-range uses for the HTB.

\section{TECHNOLOGY NEEDS}

Retrieval technologies are needed to efficiently remove various types of waste from tanks with minimal water addition. A comprehensive understanding of the mechanics of waste transport is needed to optimize retrieval systems. To understand the physics of waste dislodging and conveyance, systematic testing of developmental hardware is needed. Systematic testing allows operators to fully define the capabilities and limitations of the system.

\section{BENEFITS}

TFA-developed pressurized water retrieval systems will allow wastes ranging in consistency from liquid to salt cake to be removed from tanks with a minimum of add water and minimal added strain on leaking tanks. Completion of mechanics studies and testing in the HTB will permit the generation of essential dynamic data and the verification of mining strategy. This is the only source of this kind of data prior to cold testing of the first generation Long Reach Arm. These data are required for successful design and procurement of the arm.

\section{ACCOMPLISHMENTS}

Hanford, INEL, and ORNL have compiled respective site needs and data for reference, defining waste characterization, measured and predicted properties of the waste to be retrieved, and target retrieval schedules. These sites have contributed to the HTB Testplan which was finalized in December 1994. The gantry robot for the testbed has been received by Hanford and will begin mechanics, hydraulics, and simulant testing in 1995 .

\section{COLLABORATION/TECHNOLOGY TRANSFER}

The high-pressure jet scarifier is being developed by Quest Integrated of Washington, a leader in the

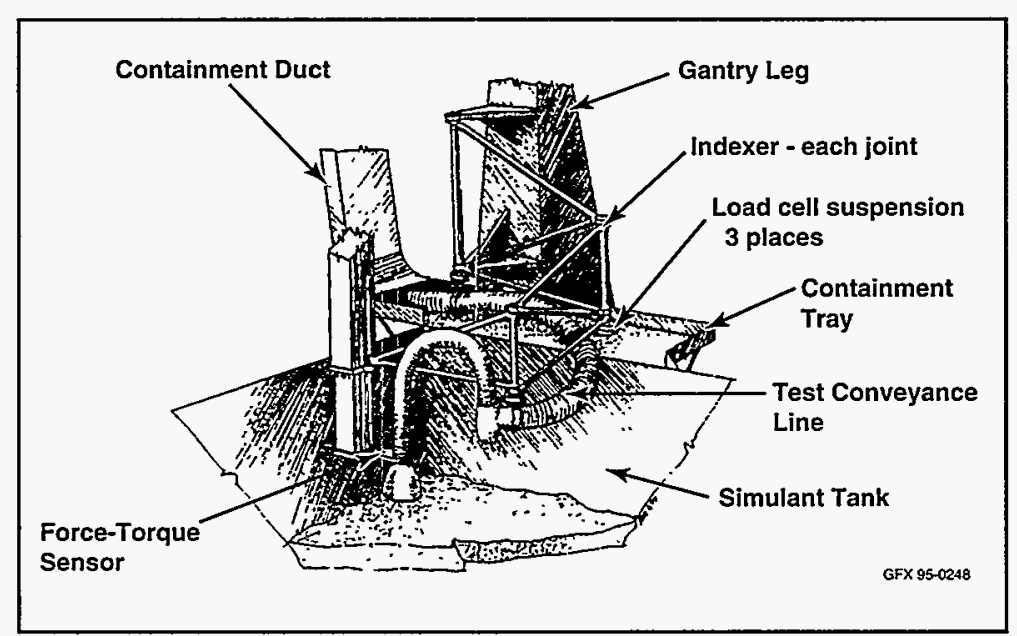
field of high-pressure water jet precision cleaning and cutring. The University of Missouri-Rolla and Dr. Clayton T. Crowe of Washington State University are developing a medium pressure water jet mining end effector, and are also collaborating in the design and testing of the dislodgers and conveyance systems. Washington State University is also working with PNL in modeling and testing models of threephase flow for better engineering of conveyance systems.

Figure 2.2. Hydraulic Testbed. 
For more information, please contact:

Jim Lee

Characterization and Retrieval

Program Manager

Sandia National Laboratories

Richland, WA 99352

(509) 376-7439

\section{Michael W. Rinker}

Principal Investigator

Battelle Pacific Northwest Laboratory

P.O. Box 999

Richland, WA 99352

\section{Roger Christensen}

Technical Program Officer

U.S. Department of Energy

Richland Operations Office

P.O. Box 550

$3230 \mathrm{Q}$ Avenue

Richland, WA 99352

(509) 372-4606
TTP Number: RL452002

\section{BIBLIOGRAPHY OF KEY PUBLICATIONS}

B.K. Hatchell, O.D. Mullen, J.A. Yount, Experimental Objectives, Test Program and Data Requirements: Hydraulic Testbed for Full-Scale Testing of Waste Dislodging and Conveyance Processes, Pacific Northwest Laboratory and Westinghouse Hanford Company, Richland, Washington, 1994.

B.K. Hatchell, O.D. Mullen, T.A. Stewart, J.A. Yount, Functions, Requirements, and Systems Description: Hydraulic Testbed for Full-Scale Testing of Waste Dislodging and Conveyance Processes, Pacific Northwest Laboratory and Westinghouse Hanford Company, Richland, Washington, 1994.

J.A. Bamberger, M.A. McKinnon, D.G. Alberts, D.E. Steele, C.T. Crow, FY93 Summary Report: Development of a Multi-Functional Scarifier Dislodger with an Integral Pneumatic Conveyance Retrieval System for Single-Shell Tank Remediation, Pacific Northwest Laboratory, Richland, Washington, 1993.

J.A. Bamberger, J.M. Bates, J.K. Keska, M.R. Elmore, N.J. Lombardo, Strategy Plan: Strategy to Develop and Test a Multi-Function Scarifier End Effector with an Integral Conveyance System for Waste Tank Remediation, PNL-8477, Pacific Northwest Laboratory, Richland, Washington, 1993. 


\section{WASTE PROCESSING AND DISPOSAL}

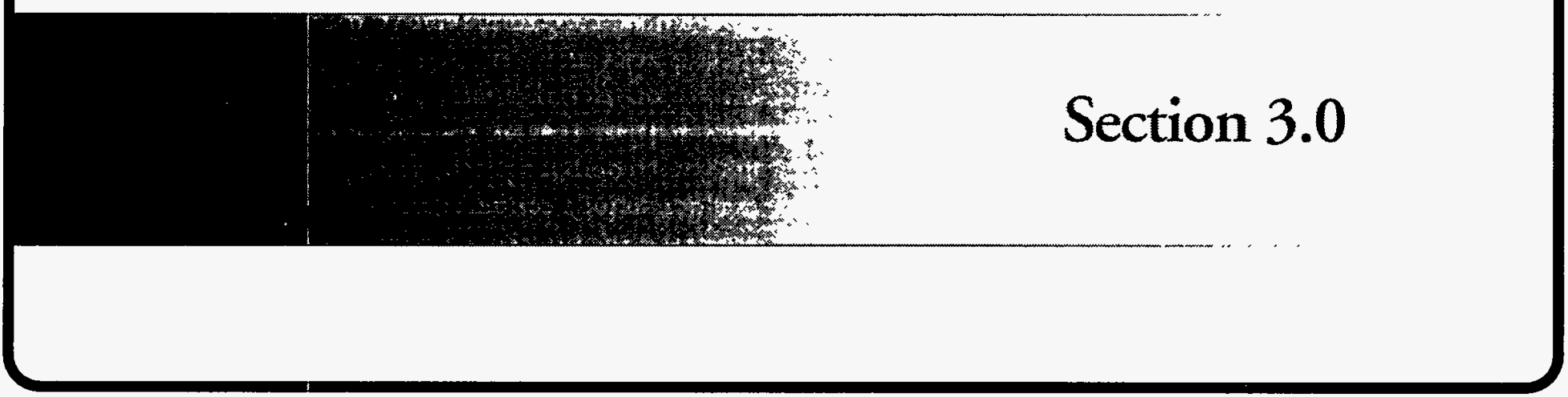

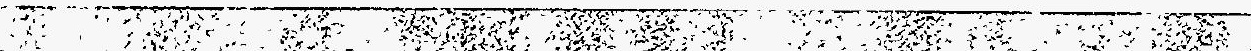


Current baseline technologies to clean up and remediate waste stored in USTs at the five DOE sites are ineffective and expensive. Technology gaps exist. Large volumes of HLW will be generated while there is only limited space in the first planned nuclear waste repository for storing HLW generated from defense activities. Even if adequate space is made available, disposal of HLW will be very expensive since each canister of vitrified HLW will cost up to $\$ 1$ million.

The Waste Processing and Disposal Subprogram seeks to demonstrate treatment and remediation technologies that will address the needs and requirements of all UST waste across the DOE Complex. The primary objective is to minimize the volume of HLW final waste being produced so disposal costs can be reduced. Performance of new and improved waste forms for disposal of LLW will also be evaluated.

Tank wastes found primarily at ORNL, Hanford, and SRS are in the form of salt cake, supernate, and sludge. They are alkaline, and have high concentrations of sodium and nitrate. They also contain organic material and various radionuclides including cesium, strontium, technetium, iodine, and transuranics, such as plutonium and americium. Technologies that efficiently remove radionuclides and hazardous materials from LLW, rendering it eligible for near-surface disposal, are critical to the subprogram. Volumes of HLW will also be kept at a minimum by separating non-transuranics and non-HLW constituents from HLW sludges and acidic wastes. Equally important are technologies that maximize releasable/reusable waste fractions and minimize chemical pretreatment.

The baseline final waste form for LLW at most sites is cement-based grout. However, grout has several deficiencies as a waste form. It increases the volume of the waste, does not effectively retain certain contaminants, and has questionable long-term stability. Alternate waste forms must therefore be tested and evaluated. TFA is testing ceramic waste forms for their ability to decrease waste volume, reduce processing and disposal costs, and enhance performance and long-term stability. 


\subsection{CESIUM REMOVAL DEMONSTRATION FOR RADIOACTIVE WASTE TREATMENT}

\section{TASK DESCRIPTION}

DOEUSTsat Hanford,SRS, INEL, and ORNL contain supernate waste with high concentrations of radioactive cesium (e.g., ${ }^{137} \mathrm{Cs}$ ). Cesium creates high radiation fields that limit waste treatment and disposal to very expensive alternatives. Treatment methods are needed to remove cesium from the liquid waste, and concentrate the cesium in high activity, remotely handled waste forms. After cesium has been removed, the rest of the waste can be treated more easily.

This task will demonstrate the removal of radioactive cesium from the high-salt-content supernate stored in the Melton Valley Storage Tanks (MVSTs). The project will demonstrate the use of a modular, mobile, ion exchange system using existing facilities for the off-gas system, secondary containment, utilities, etc. Decontamination for contact maintenance and possible transfer of the unit to other DOE facilities will also be demonstrated. The ion exchange material will be chosen based on its effectiveness in laboratory batch tests and small-scale column tests using both simulated and actual waste supernates. Design data for the ion exchange system will be drawn from several OTD programs, including TFA and the Efficient Separations and Processing Crosscurting Program activities, which are testing new materials for cesium removal from salt solutions. The success of the Cesium Removal Demonstration project will depend on experimental data from these programs to design the ion exchange system.

Project scope, planning, detailed costing, and system design will be completed in FY95. Procurement, construction, installation, and process start-up will be performed in FY96. Waste processing will continue in FY97, followed by shutdown, decontamination, and possible transfer of the system to another DOE site or to the ORNL Waste Management and Remedial Action Division (WMRAD).

\section{TECHNOLOGY NEEDS}

Cesium (e.g., ${ }^{137} \mathrm{Cs}$ ) is a major source of radioactivity (beta and gamma activities) in DOE tank wastes.
Removal of cesium is required for the subsequent processing and disposal of the tank wastes.

This demonstration helps meet regulatory requirements at several sites. The Hanford Triparty Agreement (TPA) requires that waste have sufficiently low radioactivity that it does not contaminate waste treatment equipment to such a degree that it cannot be maintained on contact. This is not possible without cesium removal. Specifically, the demonstration will support TPA milestones M-50-00-T1, M-50-01, and M-50-02 for LLW pretreatment technologies and facilities. At ORNL, the baseline method for processing supernate is liquid waste solidification. The cesium level of supernate remaining in the tanks produces a solid product that has a radiation level higher than allowable limits under DOE 49-173. Also, the new Oak Ridge Federal Facility Agreement (FFA) under discussion now requires cesium removal. This cesium removal ion exchange process gives $S R S$ an alternative to their baseline cesium removal process (In Tank Precipitation).

\section{ACCOMPLISHMENTS}

The Cesium Removal Demonstration project is being funded by OTD for the first time in FY95. However, the project is based in part on a conceptual design for a cesium removal Compact Processing Unit completed last year. Funding was also provided last year by EM-30 to perform scoping studies on facility alternatives, preliminary flowsheet development, and waste disposal alternatives. The radioactive cesium removal demonstration will take place at ORNL in FY96.

Hanford, SRS, and INEL are also developing and designing treatment systems for removal of cesium from liquid wastes. Hanford is evaluating cesium removal technologies as part of the Tank Waste Remediation System (TWRS) program. SRS is planning to use cesium removal operations for the De- 
fense Waste Processing Facility (DWPF) and is evaluating improved alternatives. INEL is considering the use of cesium removal as part of its search for alternatives to calcining for treatment of sodium bearing liquid waste from the Idaho Chemical Processing Plant. Data generated on the radioactive MVST supernates at ORNL may be applicable for removal of cesium from the liquid wastes at these facilities.

\section{BENEFITS}

This project will provide DOE with design and operating information for implementing cesium removal technology for USTs using modular, mobile systems, and state-of-the-art ion exchange methods. Decontamination for contact maintenance and possible transport to other facilities will minimize capital investment requirements for waste treatment. Removal of the cesium from the supernate at ORNL will allow the treated supernate to be processed into more economical waste forms with less radiation exposure to workers.

\section{COLLABORATION/TECHNOLOGY TRANSFER}

Technology transfer to the private sector is an intrinsic part of this project. The ion exchange materials being considered for the demonstration are currently available from a commercial supplier or are being developed for eventual commercial production. The demonstration system will be designed and constructed by a commercial supplier using preliminary design information obtained through TFA/ESP-CP studies.

\section{For further information, please contact:}

\section{C.P. McGinnis}

Waste Pretreatment and Processing Program

Manager

Oak Ridge National Laboratory

P.O. Box 2008

Oak Ridge, TN 37831-6273

(615) 576-6845

J. F. Walker

Principal Investigator

Oak Ridge National Laboratory

P.O. Box 2008

Oak Ridge, TN 37831-6330

Johnny O. Moore

Technical Program Officer

U.S. Department of Energy

Oak Ridge National Laboratory

Operations Office

Oak Ridge, TN 37831

(615) 576-3536

TTP Number: OR132008

BIBLIOGRAPHY OF KEY PUBLICATIONS

None at this time. 


\subsection{RESORCINOL/FORMALDEHYDE RESIN FOR ELUTABLE ION EXCHANGE IN COMPACT PROCESSING UNITS}

\section{TASK DESCRIPTION}

SRS has developed a resorcinol-formaldehyde ion exchange resin for cesium removal. The resin has been demonstrated to give excellent performance in testing. Other cesium removing materials either have much lower capacity or are incompatible with the high $\mathrm{pH}$ and aluminum concentration that is found in the Hanford and SRS tank wastes. In particular, the resorcinol-formaldehyde resin has 10 times the capacity of the Duolite ${ }^{\mathrm{TM}} \mathrm{CS}-100$ phenolformaldehyde resin.

The objective of this task is to test the resorcinolformaldehyde resin in column mode with tank waste simulant. See Figure 3.2. The resulting data will be critical in determining the optimum processing conditions (e.g., flow rate, elution volume and eluent). The data will also aid in the design of a modular, mobile ion exchange system for extracting cesium from alkaline tank waste, such as the Cesium Removal Demonstration. Engineering-scale tests will be run on the Skid-mounted Ion exchange Demonstration (SKID) unit at Westinghouse Savannah River Company (WSRC). This task has studied the radiolytic properties of the resin to determine radiolytic stability, radiolytic by-products, and dose dependence of the resin's performance.

\section{TECHNOLOGY NEEDS}

Ion exchange is one of the proposed technologies to remove cesium and strontium from HLW found in USTs. Due to the somewhat unique chemical characteristics of the tank wastes (i.e., high $\mathrm{pH}$ and aluminum concentration), most common ion exchangers are not suitable for their processing. The resorcinol-formaldehyde resin has been demonstrated to give excellent performance with tank wastes. Its high capacity will reduce the size of process equipment.
Cesium removal has regulatory drivers at several sites. The Hanford TPA requires so waste have sufficiently low radioactivity so it does not contaminate waste treatment equipment to such a degree that it cannot be maintained on contact. This is not possible without cesium removal. Specifically, the demonstration will support TPA milestones $M-50$ 00-T1, M-50-01, and M-50-02 for LLW pretreatment technologies and facilities. At Oak Ridge, the baseline method for processing supernate is liquid waste solidification. The Cs level of supernate remaining in the tanks produces a solid product that has a radiation level higher than allowable limits under DOE 49-173. Also, the new Oak Ridge FFA under discussion now requires cesium removal. This cesium removal ion exchange process gives Savannah River an alternative to their baseline cesium removal process (In Tank Precipitation).

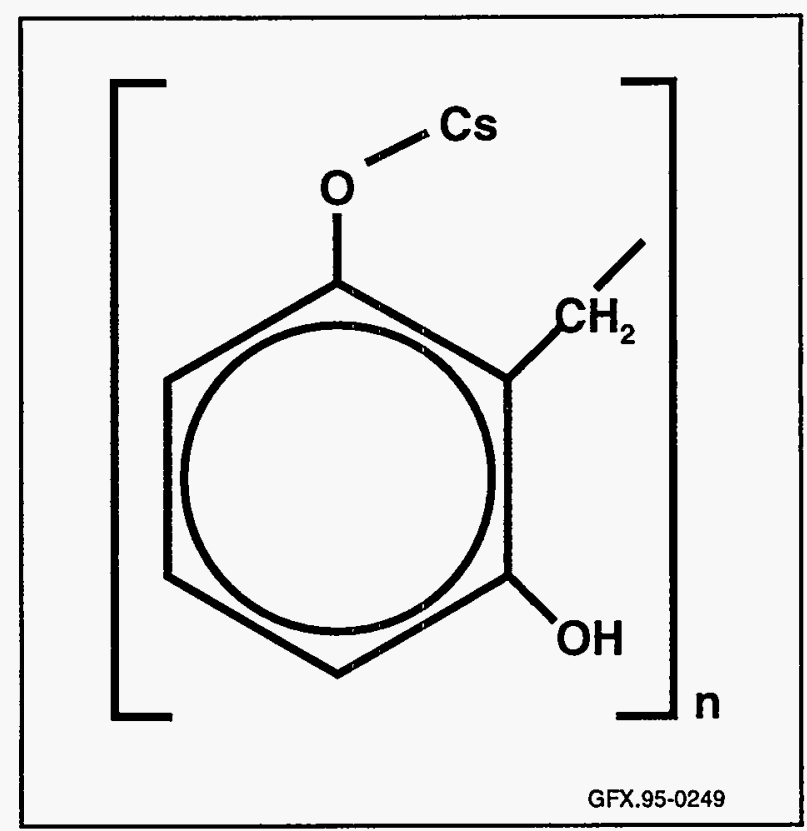

Figure 3.2. Resorcinol-Formaldehyde Resin. 


\section{ACCOMPLISHMENTS}

Optimum operating conditions, such as extraction and elution flow rates, have been developed. Radiolysis studies on the resin have also been completed. The resin is stable up to a dosage of $5 \times 10^{8} \mathrm{rad}$. A higher dosage causes some loss of extraction efficiency in a high $\mathrm{pH}$ environment, but not in water. Degradation of the resin by a hydroxide ion assisted oxidation mechanism has been determined by Clark Atlanta University researchers.

\section{BENEFITS}

Removal of radionuclides such as cesium and strontium from high level tank waste will allow a much smaller volume of waste to be vitrified and maintained in final waste form storage. Additionally, unlike many ion exchange resins, resorcinol-formaldehyde can be eluted with acid to remove the cesium, further concentrating the cesium stream sent for vitrification. This method yields significant cost savings to DOE.

\section{COLLABORATION/TECHNOLOGY TRANSFER}

The resorcinol-formaldehyde resin is manufactured by Boulder Scientific Company. Interest has also been expressed by Georgia Pacific Company and Rohm \& Haas. A contract with Clark Atlanta University is in place to conduct experimental study on the degradation properties of the resin. A second contract, with Purdue University, will develop the Purdue VERSE ion exchange model to derive process design parameters for the use of resorcinolformaldehyde resin with alkaline high level wastes. British Nuclear Fuel, Inc. will provide technical support and make modifications to the SKID unit for the resin demonstration.
For more information, please contact:

\section{C.P. McGinnis}

Waste Pretreatment and Processing Program

Manager

Oak Ridge National Laboratory

P.O. Box 2008

Oak Ridge, TN 37831-6273

(615) 576-6845

J. P. Bibler

Principal Investigator

Westinghouse Savannah River Company

Savannah River Technology Center

773-A B-132

Aiken, SC 29808

Michael O'Rear

U.S. Department of Energy

Savannah River Field Office

P.O. Box A

Aiken, SC 29808

\section{BIBLIOGRAPHY OF KEY PUBLICATIONS}

Bibler, J.P., Year End Report for UST-Cesium Extraction Testing Project DOE/DT\&E TTP\# SR132001 (U), WSRC-RP-94-146, Revision 0, Westinghouse Savannah River Company, Aiken, SC, February 1994.

Bibler, J.P., A Comparison of Duolite $\mathrm{CS}-100$ and SRS Resorcinol/Formaldehyde Ion Exchange Resins with Three High Level Waste Simulants Before and After -Irradiation (U), WSRC-RP-91, Westinghouse Savannah River Company, Aiken, SC, December 1991. 


\subsection{COMPREHENSIVE SUPERNATE DEMONSTRATION, TESTING, AND EVALUATION}

\section{TASK DESCRIPTION}

This task tests and evaluates technology components of a complete system-level plan for handling and processing sludge and supernate from USTs. The current focus is on the removal of radionuclides from supernate. This project had earlier emphasized the understanding of sludge dissolution and the development of sludge dissolution treatments.

The project tests individual technologies for radionuclide extraction in bench-scale batch experiments in a hor cell on real wastes from the ORNL Melton Valley Storage Tanks. The next phase of this project will test these radionuclide-specific sorbents in series. Comprehensive testing of each individual pretreatment technology is necessary to:

- Establish the best combination of processes;

- Verify that the selected technologies are compatible;

- Provide a realistic assessment of the performance of the individual processes; and

- Generate operating results which will be useful for pilot scale design and demonstration.

Processes and technologies will be tested and evaluated for removal of cesium, strontium, and rechnetium from supernate using ion exchange and solid extractants.

Another component of this project is a technical interchange with the Commissariat de l'Energie Atomique (CEA) in France. This interchange continues to examine the technical problems associated with the removal of actinides from acidic waste streams. While the wastes at Hanford, ORNL, and SRS are alkaline, the wastes at INEL are acidic. Also, large volumes of acidic wastes may be produced if Hanford, SRS, and ORNL pursue acid dissolution of their sludges. This exchange is focusing on the French DIAMEX process, which uses diamides as extractants to remove the actinides. This process will be evaluated against comparable U.S. extraction technologies, such as the TRUEX process.

\section{TECHNOLOGY NEEDS}

Radionuclides constitute only a small portion of DOE tank waste. In retrieving, processing, and disposing of these wastes, separation technologies are the primary means to chemically partition and concentrate the radionuclides to minimize the volume of HLW to be vitrified. It is estimated that the volume of waste to be vitrified can be reduced by a factor of 10 to 200 using separation technologies. Removal of the radionuclides also reduces shielding requirements and makes further processing of the hazardous components of the waste safer and more efficient.

Comprehensive bench-scale testing on actual wastes is the best way to ensure that individual process technologies will achieve the required degree of performance in an integrated system. Evaluation and testing of comparable technologies will ensure that the most appropriate processes will be used. It will also provide the necessary data required for further scale-up, demonstration, and transfer of the technologies.

\section{ACCOMPLISHMENTS}

Six liters of supernate and sludge from MVST W-25 were retrieved and transferred to hot cells at ORNL. The wastes were centrifuged and filtered to separate the liquid supernate from the sludge. The dissolution behavior of MVST sludge solids was examined using solutions of sodium hydroxide, nitric acid, and mixtures of nitric and hydrofluoric acids, to determine radionuclide distribution after each dissolution step. The distribution coefficients and 
percent of cesium removal from supernate were measured for several ion exchange materials. The most promising sorbents for cesium removal from supernate were resorcinol/formaldehyde, crystalline silicotitanate, and potassium cobalt hexacyanoferrate (II). Additional sorbents are now being evaluated for strontium and technetium removal from supernate.

In early 1994, an ORNL engineer was assigned to a CEA site to work on waste remediation research and development (R\&D). During this 18 month assignment, the engineer is developing an understanding of the French waste management programs. The focus is on three key $R \& D$ areas for the DIAMEX process:

- Developing a method to control or suppress the extraction Mo (VI) by malonamides;

- Determining what caused hydraulic problems during the hot demonstration of the mixer/settler of the extraction bank; and

- Addressing the use of centrifugal contactors for the DIAMEX process.

Substantial progress has been made on the first $\mathrm{R} \& \mathrm{D}$ area, which is needed to prevent formation of a third phase. The hydraulic problem in the second area was eliminated by a modification to the impeller in the organic discharge system. The success of this technical interchange has led to discussions about additional interchanges and possibly demonstration of French technologies in the United States.

\section{BENEFITS}

Technologies evaluated in this task are expected to apply to the remediation of tank waste supernates at most DOE sites with similar waste streams. The separation and concentration of the soluble radionuclides will result in a significantly smaller amount of radioactive waste disposal for long-term storage. Removal of the radioactive components will reduce shielding requirements and simplify the downstream process for removing nitrates and other toxic or hazardous components in the salt solution.
The interaction with the French CEA will allow the transfer of technology from the French CEA to the U.S. DOE. DOE will have a broader range of options from which to choose the best available technology. The French benefit from having a fulltime, skilled researcher with a knowledge of the U.S. fuel cycle chemistry to assist in their research.

\section{COLLABORATION/TECHNOLOGY} TRANSFER

Information developed from the supernate testing will be submitted to the DOE program manager for dissemination. Results of the tests will be presented to researchers at the DOE sites through workshops, program reviews, and technical meetings. Technical interchange with the French CEA has been initiated to evaluate French technologies for HLW treatment, and to explore possibilities of technical collaborations in mutually beneficial areas.

For more information, please contact:

C. P. McGinnis

Waste Pretreatment and Processing Program Manager

Oak Ridge National Laboratory

P.O. Box 2008

Oak Ridge, TN 37831-6273

(615) $576-6845$

\section{B. Z. Egan}

Principal Investigator

Oak Ridge National Laboratory

P.O. Box 2008

Oak Ridge, TN 37831-6273

J. L. Collins

Principal Investigator

Oak Ridge National Laboratory

P.O. Box 2008

Oak Ridge, TN 37831-6273 
R. T. Jubin

Principal Investigator

Oak Ridge National Laboratory

P.O. Box 2008

Oak Ridge, TN 37831-6273

Johnny O. Moore

Technical Program Officer

U.S. Department of Energy

Oak Ridge Operations Office

P.O. Box 2001

Oak Ridge, TN 37831-8620

(615) 576-3536
TTP Number: OR132008

\section{BIBLIOGRAPHY OF KEY PUBLICATIONS}

R. G. Anthony, C. V. Phillip, and R. G. Dosch, Selective Adsorption and Ion Exchange of Metal Cations and Anions with Silico-Titanates and Layered Titanates, Waste Management '93, Vol. 13, 503-512, 1993.

S. F. Marsh, Z. V. Svitra, and S. M. Bowen, Distribution of 14 Elements of 60 Selected Adsorbers from Two Simulant Solutions (Acid-Dissolved Sludge and Alkaline Supernate) for Hanford HLW Tank 102-SY, LA-12654, UC-940, Los Alamos National Laboratory, Los Alamos, NM, October 1993.

J. P. Bibler, R. M. Wallace, and L. A. Bray, Testing a New Cesium-Specific Ion Exchange Resin for Decontamination of Alkaline High-Activity Waste, Waste Management '90, Vol. 2, R.G. Post, Ed., pp. 747-751, 1990. 


\section{TASK DESCRIPTION}

The TRUEX process is a solvent extraction procedure that can efficiently separate transuranic (TRU) elements (e.g., $\mathrm{Np}, \mathrm{Pu}, \mathrm{Am}$, and $\mathrm{Cm}$ ) from aqueous nitrate- or chloride-containing wastes. These wastes are typically generated in reprocessing plant operations or in plutonium production and purification operations. The resulting solutions after extraction may be sufficiently free of TRU elements to warrant their disposal as non-TRU, low-level wastes. Furthermore, plutonium can be recovered and purified by this process. Treatment of stored wastes by the TRUEX process will significantly lower the costs of final disposal. Treatment of waste streams as they are generated will allow recycle of streams and avoidance of future waste treatment and disposal costs.

The key extractant in the TRUEX process is octyl(phenyl)- $\mathrm{N}$, -diisobutylcarbamoylmethylphosphine oxide (CMPO). It is combined with tributyl phosphate (TBP) and a diluent to formulate the TRUEX solvent. The diluent is typically a normal paraffinic hydrocarbon (either a C12-C14 mixture or ndodecane) or a non-flammable chlorocarbon such as tetrachloroethylene (see Figures 3.4a and 3.4b).

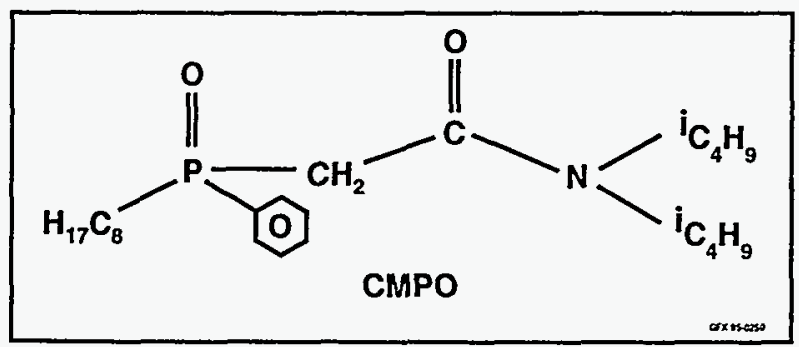

Figure 3.4a. CMPO-Extractant Structural Formula.

The Center for TRUEX Technology Development at Argonne National Laboratory (ANL) continually performs $R \& D$ to broaden the applicability of the TRUEX process in the treatment of HLW and TRU-containing waste streams.

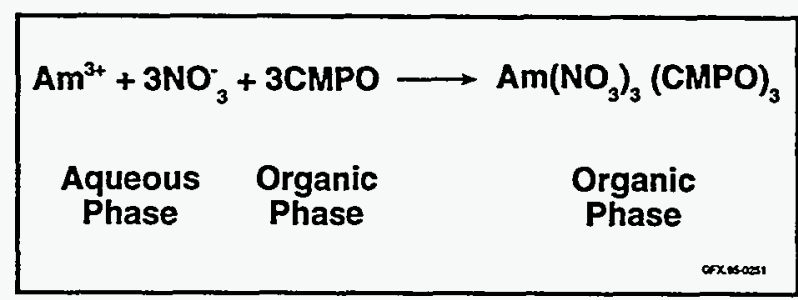

Figure 3.4b. TRUEX-Process Extraction Equilibrium Example.

Researchers developed and upgraded the Generic TRUEX Model (GTM) to assist in designing feedand site-specific processes and evaluating their economics. The GTM is a user-friendly computer software that models and predicts the TRUEX extraction behavior, calculates TRUEX flowsheets, and estimates space and cost requirements for installation. The GTM runs on a personal computer (IBM-compatible or Macintosh), and is executed by Microsoft Excel software.

The objective of the current task is to validate and refine the GTM's ability to design flowsheets for specific feeds and process goals, and to predict extraction behavior of feed components and potential processing difficulties. This task also aims to discover and identify $R \& D$ needs for getting TRUEX ready for broader implementation. The TRUEX processing of actual HLW and TRU wastes at Oak Ridge National Laboratory (ORNL) will validate the GTM. Finally, ANL will cooperate with the Power Reactor and Nuclear Fuel Development Corporation (PNC) of Japan to model their data on continuous TRUEX processing of high-level waste.

\section{TECHNOLOGY NEEDS}

If the concentration of TRU in waste streams can be lowered to below $100 \mathrm{nCi} / \mathrm{g}$ of solid, the waste can be classified as non-TRU. Additionally, if the radioactivity of other isotopes, such as ${ }^{137} \mathrm{Cs}$ and ${ }^{90} \mathrm{Sr}$, is reduced to an acceptable level, the wastes will be eligible for near-surface disposal. Use of the TRUEX 
process to treat TRU waste will greatly reduce the volume of HLW, resulting in high cost savings during disposal.

The GTM is an indispensable tool in designing siteand feed-specific TRUEX flowsheets and estimating the space and cost requirements for a TRUEX process installation. The continuous enhancement of the GTM through improved thermodynamic and computer modeling will require a parallel validation of the model by collecting laboratory and pilot-plant data.

\section{ACCOMPLISHMENTS}

Modifications to the GTM have allowed design of a TRUEX processing flowsheet for ORNL Mark 42 targets. Test runs using the Mark 42 dissolution feed material have successfully been concluded, with predicted and actual results in close agreement. Data collection for zirconium and fluoride has been completed. Additional speciation for nitrate complexes has been added to the model. Validation of the GTM using PNC data was completed. Version 3.1 of the GTM has been completed, tested, and released.

\section{BENEFITS}

Removing the TRU components from the bulk of waste being made into HLW glass will decrease disposal costs. Development of the TRUEX model aids researchers in improving the TRUEX process and increasing the efficiency of TRU extraction.

\section{COLLABORATION/TECHNOLOGY TRANSFER}

All technical users at ANL, Hanford, INEL, LANL, ORNL, and Rocky Flats share information pertaining to further development and use of the model. University partners at the University of Illinois and Spring Arbor College, MI, are collecting extraction data. Collaboration also exists to demonstrate the process and model the data with the PNC of Japan.
For more information, please contact:

\section{P. McGinnis}

Waste Pretreatment and Processing Program Manager

Oak Ridge National Laboratory

P.O. Box 2008

Oak Ridge, TN 37831-6273

(615) 576-6845

\section{George Vandegrift}

Principal Investigator

Argonne National Laboratory

9700 South Cass Avenue

Argonne, IL 60439-4837

(708) 252-4513

\section{Steve Webster}

Technical Program Officer

U.S. Department of Energy

Chicago Operations Office

9800 South Cass Avenue

Argonne, IL 60439

\section{TTP Number: CH232001}

\section{BIBLIOGRAPHY OF KEY PUBLICATIONS}

G. F. Vandegrift, S. Betts, D. B Chamberlain, et al., Separation Science and Technology Semiannual Progress Report, October 1991 - March 1992, ANL-93/38, Argonne National Laboratory, Chicago, IL, January, 1994.

C. E. Johnson, G.F. Vandegrift,J.K. Bates, etal., Nuclear TechnologyProgramsSemiannual Progress Report,AprilSeptember 1991, ANL-93/21, Argonne National Laboratory, Chicago, IL, July 1993.

G. F. Vandegrift, D. B. Chamberlain, R. A. Leonard, et al., Development and Demonstration of the TRUEX Solvent Extraction Process, Proceedings of the 19th Annual Nuclear WasteSymposium, Waste Management '93, Tucson, AZ, February 28 - March 4, 1993, Vol. 2, pp. 1045-1050, 1993. 


\subsection{THE NITRATE TO AMMONIA AND CERAMIC PROCESS}

\section{TASK DESCRIPTION}

The Nitrate to Ammonia and Ceramic (NAC) process involves chemically reducing the nitrate, contained in mixed (hazardous and radioactive) tank waste, to gaseous ammonia utilizing a new technology developed at ORNL. Florida International University (FIU) is working with ORNL on the development of this process. The NAC process can achieve concentrations of nitrate below drinking water standards. See Figure 3.5.

It is expected that radioactive species such as plutonium and strontium will enter the solid ceramic phase during the reduction of the nitrate anion. The alumina-based ceramic host matrix will undergo calcination, pressing, and sintering, which will generate a solid waste form capable of binding nearly all elements. Sodium will be in a nepheline ceramic phase. In the process, radioactive contaminated scrap aluminum from various DOE sires could be shredded and used as feed to the NAC reactor. Therefore, the need for decontamination of such metal will be eliminated.

Laboratory experiments have shown that a decontaminated solid nitrate waste stream can be solidified by using a catalytic material. This material decomposes the sodium nitrate to innocuous gas and a liquid secondary waste stream containing only trace amounts of nitrate. The process solidifies the radioactive fraction of the waste at rather low temperatures $\left(50-90^{\circ} \mathrm{C}\right.$; significantly lower than vitrification) and reduces final waste volumes 55 percent to 75 percent (as compared to a 30 percent to 40 percent volume increase by grouting).

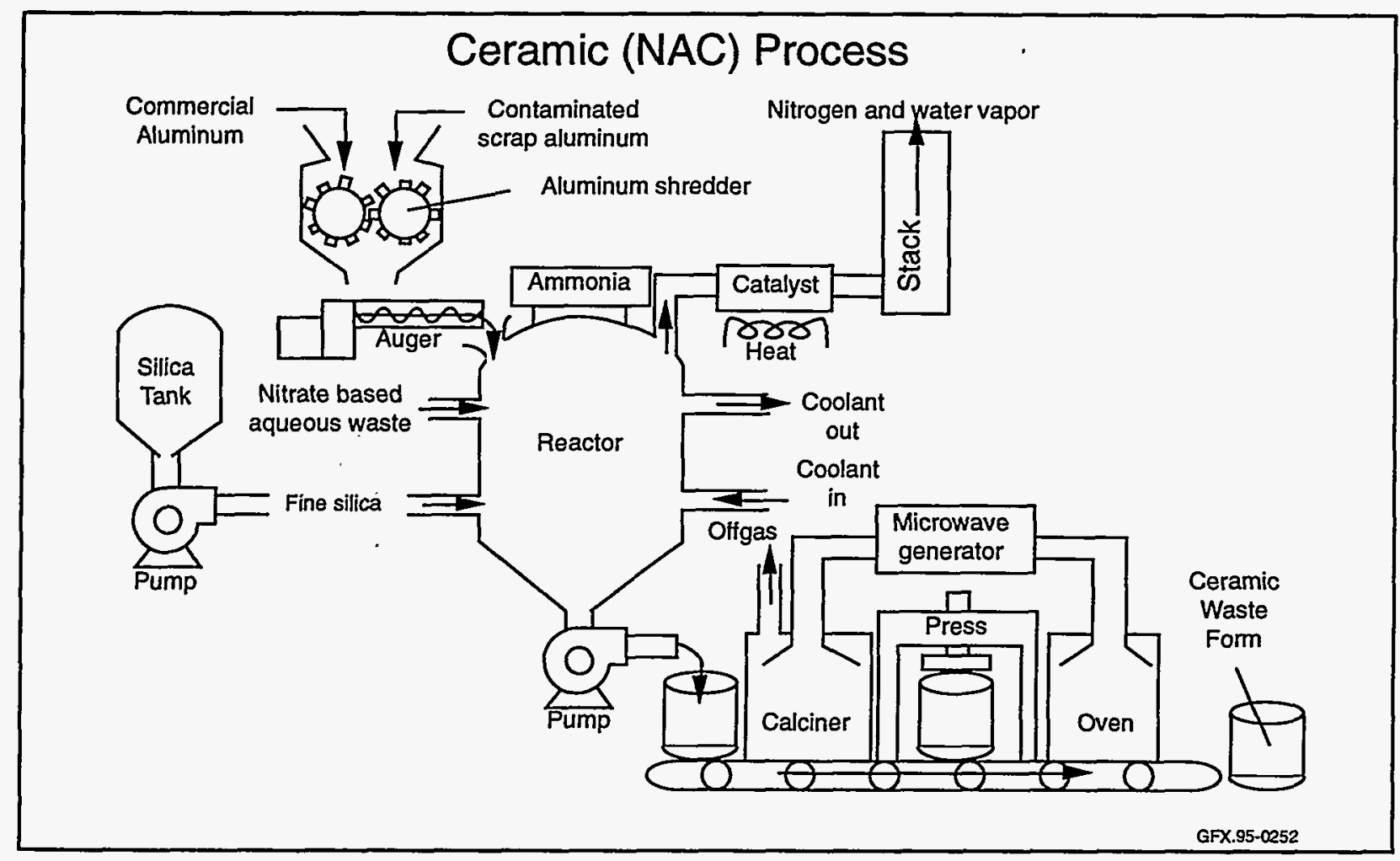

Figure 3.5. The Nitrate to Ammonia Ceramic Process. 


\section{TECHNOLOGY NEEDS}

The NAC process addresses the primary liquid and sludge leachate component at Hanford and the Melton Valley Storage Tank in Oak Ridge. USTs at both sites contain large amounts of highly alkaline, nitrate-based mixed liquid waste. Current plans are to place the liquid phase in grout and the acidwashed solids (TRUEX process) in glass. The NAC project will support these objectives by generating innocuous gaseous and liquid products and a lowvolume, chemically stable solid waste form.

\section{ACCOMPLISHMENTS}

A patent on the NAC process was awarded to Martin Marietta Energy Systems Inc.

The overall efficiency of the use of aluminum metal reactant has been increased from 50 to 91 percent by operating the NAC reactor in a continuous mode. This operation mode will:

- Reduce processing costs by decreasing the amount of aluminum (a costly reactant) to approximately $\$ 2 / \mathrm{kg}$ of nitrate converted; and

- Operate with waste solution feeds containing nitrate at near saturation.

Sintering temperatures of the final ceramic product have been reduced by $150^{\circ} \mathrm{C}$ to $1350^{\circ} \mathrm{C}$, while sintering time was cut in half.

The following experiments were performed:

- Baseline sodium nitrate solution tests and tests using Hanford formula salt cake solutions at a nitrate concentration of 3.1 molar to determine the hydrogen production and efficiency of nitrate reduction at various nitrate concentration.
- Bench-scale tests to determine the characteristics of technetium in the NAC process.

The following activities were completed at FIU:

- A laboratory has been designated as the NAC laboratory. A five liter Bioflo IIC chemical reactor and support equipment have been installed.

- Viscosity tests have been initiated.

- The chemical compositions and the leachability of the NAC waste forms to various ceramic and glass waste forms for high level waste were compared.

\section{BENEFITS}

Nitrates are oxidizers, are limited by regulations in their allowable concentrations in drinking water, and interfere with the process of making glass. The NAC process reduces nitrate to ammonia, and immobilizes strontium and any soluble actinides, lanthanides, and alkali metals, including cesium in the ceramic waste form, to produce an inert waste suitable for disposal. The process can be applied to the remediation of tank waste supernates and salt cakes at most DOE sites, particularly highly alkaline supernates and sludges that contain high concentrations of salts.

\section{COLLABORATION/TECHNOLOGY TRANSFER}

ORNL is working with FIU on the engineering development and scale-up of this process. ORNL has also contracted with CUA to develop a glass waste form that could be used as an alternative to the ceramic now generated by the process. 
TTP Number: OR132008

For more information, please contact:

\section{BIBLIOGRAPHY OF KEY PUBLICATIONS}

C. P. McGinnis

Waste Pretreatment and Processing Program Manager

Oak Ridge National Laboratory

P.O. Box 2008

Oak Ridge, TN 37831-6273

(615) $576-6845$

D. D. Lee

Principal Investigator

Oak Ridge National Laboratory

P.O. Box 2008

Oak Ridge, TN 37831-6273

\section{A. Ebadian}

Department Chairman

Mechanical Engineering Department

Florida International University

University Park Campus

Miami, FL 33199

Johnny O. Moore

Technical Program Officer

U.S. Department of Energy

Oak Ridge Operations Office

P.O. Box 2001

Oak Ridge, TN 37831-8620

(615) 576-3536 


\subsection{OUT-OF-TANK MOBILE EVAPORATOR}

\section{TASK DESCRIPTION}

This task will demonstrate the feasibility of a mobile, skid-mounted, single-state, sub-atmospheric evaporator for concentrating radioactively contaminated, high salt content waste from USTs. Evaporators are being considered at DOE tank sites to concentrate waste for interim storage prior to separations and solidification processes for waste disposal.

The TFA is developing an evaporator to remove excess water from a 4 to 5 molar sodium nitrate solution contaminated primarily with ${ }^{137} \mathrm{Cs}$ and ${ }^{90} \mathrm{Sr}$ at activity levels of about $8 \mathrm{mCi} / \mathrm{l}$ and $0.2 \mathrm{mCi} / \mathrm{l}$, respectively. The project will evaluate the relationship between the performance of pilot-scale evaporators processing surrogate solutions, and full-scale units processing actual waste. It will also determine processing capabilities (such as decontamination factors), identify potential operating/maintenance problems for remotely operated evaporators, and evaluate the feasibility of decontaminating evaporator systems for hands-on maintenance and the possibility of moving the unit to another site.

An evaporator demonstration will be conducted at ORNL to process 25,000 gallons of liquid LLW supernate from Melton Valley Storage Tanks. The object of the demonstration is to evaporate the waste to a level approaching supersaturation of the dissolved salts. The demonstration will return 19,000 gallons of concentrated waste to the tanks and 6,000 gallons of condensate to the laboratory's process waste system.

\section{TECHNOLOGY NEEDS}

Only the double-shell tanks at ORNL are in compliance with the FFA between DOE, EPA, and the Tennessee Department of Environment and Compliance. Evaporators offer the possibility of removing water from tank waste, thus making space in the double-shell tanks, so waste from noncompliant tanks can be moved to compliant tanks. The alternative to evaporation would be to solidify the waste in noncompliant tanks, which produces a waste form for which there is currently no permitted storage.

\section{ACCOMPLISHMENTS}

Technical specifications for the evaporator system were developed, and a purchase requisition was issued. The project team evaluated the bids received and awarded the contract to Delta Thermal in October 1994. Modifications to the System Safety Analysis for the facility that will house the evaporator have begun. The Oak Ridge Engineering Division has begun work on a feasibility study to define requirements for the installation of the evaporator system.

\section{BENEFITS}

Evaporation will increase underground storage tank capacity, allowing the waste to be safely stored in compliance with regulations and agreements until appropriate treatment is available.

\section{COLLABORATION/TECHNOLOGY TRANSFER}

In the past, ORNL has worked with both Licon and Arrisan on evaporator development. The evaporator contract for the 1996 demonstration was awarded to Delta Thermal, based on a competitive bid. 
For more information, please contact:

C.P. McGinnis

Waste Pretreatment and Processing Program

Manager

Oak Ridge National Laboratory

P.O. Box 2008

Oak Ridge, TN 37831-6273

\section{A.J. Lucero}

Principal Investigator

Oak Ridge National Laboratory

P.O. Box 2008

Oak Ridge, TN 37831-6044

Johnny O. Moore

Technical Program Officer

U.S. Department of Energy

Oak Ridge Operations Office

P.O. Box 2001

Oak Ridge, TN 37831-8620

(615) $576-3536$

\section{BIBLIOGRAPHY OF KEY PUBLICATIONS}

None at this time. 


\section{TASK DESCRIPTION}

This task will evaluate available solid/liquid separation technology for pretreatment of underground storage tank wastes. SRS has extensive knowledge of crossflow filtration from the In-Tank Precipitation (ITP) process. Fine particulates suspended in liquid waste have a damaging effect on treatment processes such as ion exchange. Crossflow filtration is a pretreatment method that can separate insoluble solids to prevent downstream processing interference. The task will integrate laboratory scale filter testing with actual full-scale operation to permit correlation between units, and comparison between simulant and actual waste.

This activity will also evaluate the filtration needs of proposed pretreatment processes for underground storage tank wastes at Hanford and ORNL, with initial estimates of equipment sizes, pump requirements, and chemical cleaning methods. The evaluation will help determine and rank the various filtration needs suitable to crossflow filtration technology, based on priority and potential for success. The ranking activity provides information needed to select the most suitable crossflow filter application for testing. Engineering and chemical testing of the desired crossflow filter application will be completed using nonradioactive simulated waste.

\section{TECHNOLOGY NEEDS}

Fine particulates suspended in liquid wastes have a harmful effect on radioactive waste treatment processes such as ion exchange. These effects include ion exchange bed fouling, reduced removal efficiencies, higher shielding requirements, premature breakthrough of radioactive particulates, and interference of downstream waste disposal processes. Treatment processes for aqueous high-level wastes are expected to require pretreatment to separate insoluble solids from the liquid. Crossflow filtration has been demonstrated as an efficient method to remove insoluble solids. This activity will determine the best available filtration technology to remove these insoluble solids.

\section{ACCOMPLISHMENT}

Extensive research on the Mott filters used in the ITP process has been ongoing at SRTC. The information and experience gathered from this testing will provide valuable input to the evaluation and testing in this program.

\section{BENEFITS}

Removal of fine suspended solids in tank supernate will improve the efficiency of downstream processing, extend the life of ion exchange materials, and improve radionuclide removal efficiency.

\section{COLLABORATION/TECHNOLOGY}

\section{TRANSFER}

The experience and knowledge gained from the ITP process, along with a decade of ongoing crossflow filter research, will be applied to this activity and transferred to scientists and engineers at Hanford and ORNL. The research will be available in the form of data reports for other sites and divisions. Significant input from Hanford and ORNL personnel to WSRC will be needed to identify waste stream characteristics and needs. Information will be obtained from West Valley on the supernate filtration process currently in use. 
For further information, please contact:

C. P. McGinnis

Waste Pretreatment and Processing Program

Manager

Oak Ridge National Laboratory

P.O. Box 2008

Oak Ridge, TN 37831-6273

(615) 576-6845

D. J. McCabe

Principal Investigator

Westinghouse Savannah River Company

P.O. Box 616

Aiken, SC 29801-0001

(803) 725-2054

\section{Michael O'Rear}

U.S. Department of Energy

Savannah River Operations Office

P.O. Box A

Aiken, SC 29801

\section{BIBLIOGRAPHY OF KEY PUBLICATIONS}

None at this time. 


\section{CROsscutTing PROGRAMS}

\section{Section 4.0}




\subsection{CROSSCUTTING PROGRAMS}

EM-50 has three crosscutting programs: Characterization, Monitoring and Sensor Technology, Robotics, and Efficient Separations and Processing. Each of these programs has technology development activities that focus on tank remediation. Examples of these include:

Characterization, Monitoring and Sensor Technology:

- Development of sensors for in situ monitoring of toxic or explosive head space gases such as $\mathrm{H}_{2}$, $\mathrm{NOx}, \mathrm{NH}_{3}$, and hydrocarbons, in USTs;

- Development of methods such as fourier transform infrared (FTIR) photoacoustic spectroscopy (PAS) for the quantitative analysis of reactive compounds such as nitrates and ferrocyanides in tank waste; and

- Development of acoustic monitoring instruments, that indicate how well mixed the sludge and supernate components of tank waste are, to be used with mixer pumps during retrieval.

Robotics:

- Development of a robotics test bed, a full-scale development facility for the evaluation of new manipulator-based-retrieval technologies. It will assist the development, testing, and demonstration of waste retrieval methods, equipment, and procedures as well as validate simulation codes.

- Development of a high-fidelity simulation package to enable rapid evaluation of vendor designs and development concepts. Simulation extrapolates experimental data retrieved from the test bed and other test sources to match scale and configuration of planned retrieval systems.

- Development of a high-speed digital communications system to connect simulation and experimental equipment that is distributed among the contributing laboratories. It enables the operation of robotic systems from remote nodes (other laboratories), as well as linking combinations of hardware and software assets at multiple sites to form an integrated test and demonstration capability.

Efficient Separations and Processing:

- Development and testing of several compounds (including crystalline silicotitanate, pillared clays, and potassium cobalt hexacyanoferrate) designed to extract radionuclides such as cesium and strontium from tank waste;

- Development of sorbents for extraction of technetium and actinides from liquid waste; and

- Development of sludge washing and processing systems.

For more information on these programs, please see the Robotics Technology Crosscutting Program, the Efficient Separations and Processing Crosscutting Program, and the Characterization, Sensor, and Monitoring Crosscutting Program Technology Summaries, 1995. 


\section{SITE SPECIFIC TECHNOLOGY DEVELOPMENT ACTIVITIES}

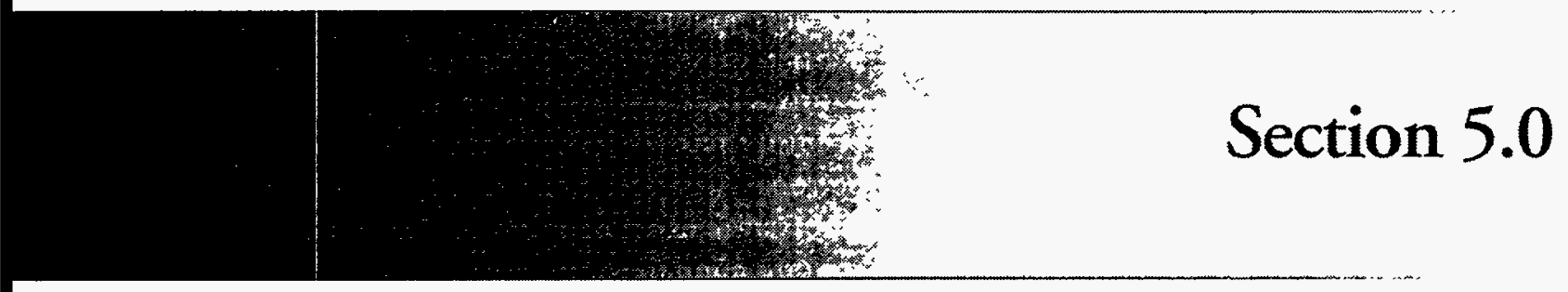




\subsection{SITE SPECIFIC TECHNOLOGY DEVELOPMENT ACTIVITIES}

The mission of the TFA is to establish an efficient link between technology development and the final users of improved technology systems. TFA's mission also includes improving coordination between technology development activities. In addition to OTD, development of technologies to make tank remediation safer and more cost effective has been done by a variety of organizations, including:

- The Tank Waste Remediation Systems (TWRS) at Hanford;

- The Office of Environmental Restoration (EM-40) and the Office of Waste Management (EM-30) at ORNL;

- The SRTC; and

- The Office of Waste Management (EM-30) at INEL.

Technology development by these organizations has, by design, been more site specific than that of OTD. Nevertheless, DOE recognizes that sites may have common needs which enhance the ability to leverage off one another. This coordination is one function of the TFA.

This section of the Technology Summary book contains short descriptions of some of the technology development initiatives by each of the organizations listed above. 


\section{Hanford - Safety}

Flammable Gas Safety Issue. The release of flammable gases into the dome space of Tank 241-SY-101 and other waste tanks at the Hanford Site is a top priority safery issue. Periodic releases of these gases can result in concentrations in the dome space above the Lower Flammability Limit (LFL) for hydrogen. Such venting of gases is expected to keep reoccurring until some form of mitigation action is taken.

A pilot-scale mixer pump was installed in 241-SY-101 to test its efficacy as a mitigation measure in preventing periodic releases of hydrogen. Work currently focuses on modeling and design of full scale mitigation systems for SY-101, SY-103, AW-101, and AN tanks. Specific activities include:

- Collecting prior tank data and instrumentation configuration and perform error analyses on tank instruments;

- Developing and deploy void meter and viscometer in each tank to characterize initial waste properties and report results;

- Performing computational modeling to support safety analysis and predict mixer pump performance;

- Preparing the mixer pump test plan with WHC support and provide Test Review Group (TRG) support during testing. After DACs is installed, provide weeklyl monthly data reports;

- Providing accessibility to tank data during testing and publish the validated test data set; and

- Operating void meter and viscometer in each tank after pump operation to assess mixing effectiveness.
Dilution and heating are also being evaluated as alternatives to the mixer pump for mitigating flammable gas-generating tanks. Additional laboratory studies, computational and analytical modeling, and testing are required to demonstrate the viability of these alternatives.

Organic Safety Issue. The Organic Safety Issue comes from the organic complexants and organic degradation products of solvents that have been added to the Single Shell Tanks (SSTs) as a result of Hanford operations. These waste tanks may also contain enough sodium nitrite and sodium nitrate oxidizers to exothermically oxidize the organic compounds. Analyses show that these reactions could occur if there is sufficient concentration of fuel and oxidizer present in the waste, and if a portion of the waste is dried out and heated to temperatures above $180^{\circ} \mathrm{C}$. Double Shell Tanks (DSTs) containing organics are not considered a safety issue because the tanks contain large quantities of water. Water has been removed from SSTs due to the risk of leakage. This project is analyzing the risk from the Organic Safety Issue by studying several areas:

- Waste aging, the degradation of fuel value of the organic compounds as a result of radiation and chemical hydrolysis and/or oxidation of the original process organics;

- The energetics of potential reaction systems within the tank. These studies will allow additional analysis requirements to be identified that supplement use of Total Organic Carbons (TOC) measurements to estimate tank reactivity;

- Modeling the distribution of organics in the tank, which resulted from the addition of different organic waste streams to the tanks at different times; and

- Providing SST moisture and organic carbon content estimates based on best available information and extrapolation. 
Technology development for evaluation and definition of the Organic Safety Issue also involves developing analytical methods for analyzing chelators, chelator fragments, organic acids, other organic functional groups, and high molecular weight compounds. These methods are required to support evaluating and defining the Organic Tanks Safety Issue as well as the Flammable Gas Safety Issue.

Ferrocyanide Safety Issue. Twenty tanks are on the ferrocyanide watch-list. This safety issue is similar to the Organics Safety Issue, except that ferrocyanides provide the fuel for chemical reactions rather than organics. Such reactions could generate aerosols that might plug and rupture the high-efficiency particulate air (HEPA) filter and release radioactive materials into the environment. Researchers are evaluating and defining the safety issue associated with wastes containing potentially reactive mixtures of ferrocyanide in the following activities:

- Studying waste aging to understand the extent of ferrocyanide destruction that may have occurred during decades of storage;

- Comparing real wastes to simulated wastes to determine if the behavior observed for the simulated wastes is predictive of actual wastes;

- Studying the solubility behavior of cesium nickel ferrocyanide in order to predict the physical distribution of cesium in the tanks. Scientists believe that if the radionuclides can concentrate in "hot spots", they can create enough heat to start a chemical reaction with the ferrocyanides;

- Establishing methods to measure surface moisture, and

- Establishing qualified procedures for the quantitative measurement of cyanide species in dissolved tank waste samples.

\section{Hanford - Characterization}

Void Fraction Instrument. The Void Fraction Instrument (VFI) is a tool developed by the Westinghouse Hanford Company for measurement of the proportion of gas to sludges in tank waste.
The device consists of a two section arm. The longer section is 65 feet long and is used to deploy the 3 foot rotating section that performs the measurement. This short section is terminated by a cylindrical sampler with openings on opposing sides and a sleeve that slides over the cylinder to trap the sample. Both sections are 3 inches in diameter for insertion in 4 inch risers. The VFI was developed for tank 101-SY. Once immersed into the sludge in the tank, the 3 foot arm rotates to a 90 degree angle, positioning the sampler horizontally and open. To take a sample, the VFI is slowly lowered through the sludge allowing the sludge and gas to flow freely through the sampler. The sleeve is then used to close the sampler, which is then pressurized to measure the gas fraction of the trapped waste. The VFI was successfully deployed in tank 101-SY in December 1994. The primary objective of its deployment was to determine if significant interstitial gas buildup still occurs in the tank waste. The VFI has indicated that it does not, and that the currently employed methods for the mitigation of the build up are working. The VFI can also be used on other tanks. If a determination is made that a tank currently considered a "flammable gas tank" does not produce a lot of gas, it can be removed from the flammable tank list, thereby significantly reducing the monitoring requirements and other costs associated with its maintenance.

The VFI's project engineer was Troy Stokes from WHC. The tool's development was a team effort of WHC, PNL, LANL, and ICF-Kaiser. The team took only one year to design and deploy the device.

Gas Monitoring Systems. Hanford tank 101-SY was made famous by its violent releases of flammable gases. The highly radioactive waste generated hydrogen, nitrogen, nitrous oxide and ammonia. The violent manner in which the gases would percolate, or "burp" from the bottom of the tank had made the tank into one of Hanford's most serious safety concerns. To prevent the violent gas percolation, Westinghouse Hanford Company has installed a mixing pump that allows gradual instead of instantaneous release of gases generated inside the tank. However, the fact that the tank still produces flammable gases necessitates reliable and continuous monitoring of the tank atmosphere. 
Westinghouse Hanford Company along with Los Alamos National Laboratory have put together a Gas Monitoring System (GMS) to identify the type and concentration of gases being released inside the tank. The monitoring system was assembled from commercially available Gas Chromatographs (GC) and Fourier Transform Infrared Spectrometers (FTIR). The GCs are used to monitor hydrogen concentrations and the FTIRs to monitor nitrous oxide and ammonia. The gas samples are trapped inside the tank vent header and transported by vacuum pumps to the monitoring equipment. The gas transport tubing is trace-heated to minimize condensation during transport and to keep the sample at constant temperature. After analysis, the gas is returned back into the vent header. The gas monitoring data is gathered in real-time and the instrumentation is controlled remotely. All of the gas monitoring instruments are periodically calibrated using standard gases. For more information contact Eric Straalsund, Westinghouse Hanford Company, at (509) 376-3808.

Tank Waste Viscometer Tool. Westinghouse Hanford Company has developed a device for measuring the viscosity of tank waste and the presence of gas gaps in tank sludges. This information is needed to estimate the effectiveness of mixing pump operations and the amounts of gas being trapped within tank waste. The device basically consists of a $16 \mathrm{lbs}, 3.6$ inch diameter steel ball suspended on a cable across a stain gauge from a rotating drum. The drum and the strain gauge are installed above a 4 inch riser. The ball is lowered into the tank waste through riser. Once inside the waste the drum gets activated to pulsate clockwise and counterclockwise, in an alternating fashion, causing the ball to move vertically through the waste. The strain induced by the motion recorded. Based on that information the viscosity of the medium in which the ball is oscillating can be calculated. The device is remotely controlled, protected from exposure to tank atmosphere, and upon extraction, the ball and the cable are decontaminated. The device is in the process of being deployed in tank 101-SY.

For more information contact Troy Stokes, Westinghouse Hanford Company, by phone at (509) 376-9436, or by e-mail Troy_I_Stokes@rl.gov.

\section{Hanford-Pretreatment}

Sludge Washing and Alkaline Leach Tests. Washing of sludge with water is necessary to dissolve salts and remove the interstitial liquid containing dissolved salts, from the water-insoluble sludge components. In this manner these dissolved salt components do not contribute to the volume of the High Level Waste (HLW) glass produced on vitrification of the sludge. The separation of HLW tank liquid supernates, sludge leaching/metathesis solutions, and washing solutions from sludge is also necessary for subsequent processing of these liquids to a Low Level Waste (LLW) glass. The solid/liquid separations are required not only to achieve adequate decontamination of the liquid phase from transuranics (TRUs) and strontium, which are concentrated in the solid phase, but also to provide a solids-free feed stream to cesium and possibly strontium separation processes, most probably solid sorbents, so that those processes can operate properly.

Both PNL and LANL are conducting sludge wash/ alkaline leach tests of actual tank waste from core samples. They test small samples (approximately 5 grams) of actual waste from a variety of sludges to determine the extent of removal of components when washed with inhibited water (for corrosion), and when leached with hot caustic solutions. Leach conditions may include a range of caustic concentrations, times of reaction, and temperature. Distribution of key components (e.g., sulfate, phosphate, aluminum, chromium, and radionuclides) among the wash and leach solutions and the leached residue will be determined. PNL and LANL will coordinate their parallel investigations to ensure total comparability of results.

The basic chemical and physical properties governing the leaching and metathesis of Hanford tank waste sludges will be obtained in areas such as chemical kinetics, ion interactions in solutions and on surfaces, and transport processes governing solubility mechanism. Both experimental test and theoretical modelling efforts will be involved.

Acid Dissolution of Sludges. Some important HLW-glass-volume-limiting components of the sludge may not be sufficiently removed by simple sludge washing and alkaline leaching and metathe- 
sis. These components are present in chemical forms that may not be sufficiently dissolved in typical wash/alkaline solutions. These components are expected to be dissolved in acid media, leading to the thesis that removal of these components by alkaline leaching and metathesis can be enhanced by acid dissolution followed by reneutralization (reconstitution of sludge).

This project will conduct acid dissolution tests with actual sludges. Acidic reagents will include nitric acid, nitro/oxalic acid mixes; and nitric/hydrofluoric acid mixes. Researchers will vary the periods of time for reaction, and varying temperature, and measure the distribution of key components between the solutions and the residual solids. Results of these tests will allow the necessary optimizations/ tradeoffs necessary to determine operating conditions for sludge dissolutions and will allow accurate projection of HLW volume. Test-tube level experiments will be the major focus of this activity.

Further testing will include laboratory scale solvent extraction studies on the acid-dissolved sludges.

Sludge Settling. The separation of HLW tank liquid supernates and wash/leach solutions from sludge is necessary for subsequent processing of these liquids to produce a LLW glass. The solid/ liquid separation is required not only to adequately decontaminate the liquid phase from TRU and $\mathrm{Sr}$, which are concentrated in the solid phase, but also to provide a solids-free feed stream to $\mathrm{Cs} / \mathrm{Sr}$ separation processes, most probably solid sorbents, so those processes can operate properly. The primary solid/liquid separation will be made in-tank by settling solids and decanting the liquid phase. This technique will provide a gross separation of phases; however, the liquid phase may still contain some suspended solids and may require further removal of the solids. This second polishing phase separation will be completed in a separate facility using either filtration or centrifugation technology.

This project will conduct sludge settling tests of actual waste. Focus will be on; measuring settling times, compaction, and particle-size density/distribution before and after washing; alkaline leaching; and rewashing. Sample size has nominally been established as 1.0 liter sludge to ensure proper scaling. Effectiveness of settling agents such as flocculents will also be assessed to determine effects on settling times and compaction, if settling times are less than 1 to 2 inches per day. Characterization of the particles in the supernate is necessary to evaluate/test techniques to remove the suspended particulate matter.

The effectiveness of the separation of solids and liquids in the settle/decant step depends how close to the top of the settled solids layer the liquids can be removed without also removing some of the solid. Thus, if the liquids/sludge interface can be detected relatively accurately, liquid decanting can be maximized. This could mean fewer washing steps and, again, less liquid to be processed and concentrated prior to LLW vitrification.

Sludge Processing Science. The mixing of different types of wastes during retrieval (or storage before pretreatment) can have bad, as well as good, impacts on the HLW glass volume. One example is the possible formation of additional calcium phosphate, which would increase the quantity of phosphate remaining after caustic leaching. This project examines the potential for other adverse reacrions, and evaluates candidate mixes experimentally, first with synthetic wastes and then with actual wastes. Another aspect of this study will evaluate the impact of chemicals that may added to aid waste retrieval and transfer operations, relative to their behavior in pretreatment operations and their impacts on HLW glass volume.

Cesium Removal. This project studies three ion exchange sorbents for Cesium removal: phenolformaldehyde $\mathrm{Cs}-100$, resorcinol-formaldehyde, and crystalline silicotitanates. It will provide engineering data on the electrochemical elution for Cs-100 and resorcinol-formaldehyde, the two regenerable organic ion exchange resins. Small-scale batch testing and column testing on simulants and actual waste will provide this engineering data. The project will also develop preliminary engineering data for the new ion exchange material crystalline silicotitanate, which preliminary tests have shown may have a higher capacity, but is non-regenerable. Early testing will use actual DSSF, which is the first supernate that will be processed through the LLW pretreatment facility. 
The degrees of separation required will depend on several factors including LLW disposal criteria, and the LLW vitrification facility shielding requirements. This project will assume a maximum cesium decontamination factor of 10,000 development purposes.

Data on the alternate sorbent are needed to compare its performance to ion exchange by CS-100 or resorcinol-formaldehyde. Initial work will be done using simulant solutions over a range of compositions that are likely to be present when processing actual waste at the Hanford Site. Laboratory scale demonstration using actual waste stream samples will be done to verify simulant testing. Appropriate engineering-scale testing will follow to provide scaleup factors for plant design. Data to predict long-term stability of reagents; and environment, safety, and health (ES\&H) and economic factors will be collected and analyzed.

Sr/TRU/Tc Removal. The objective of this project is to select the most promising technologies and develop engineering data for those processes that will remove strontium, TRU and technetium from supernate, dissolved saltcake, and sludge wash and leach solutions. LANL will conduct batch and column IX tests for strontium removal from actual and synthetic DSSF and CC waste. Complexed wastes will be the focus of this activity because these wastes present the greatest challenge. Column tests with synthetic waste will be done to verify the process. Sodium titanate, pillared clays, and complexants bound on solid supports will be tested for $\mathrm{Sr}$ removal. Reillex resin will be tested for Tc removal.

The method generally used to remove traces of TRU radionuclides from alkaline solutions is carrier precipitation, generally with ferric hydroxide. Some of the alternatives that will also be tested include mixtures of ferrous and ferric hydroxide, monosodium titanate, and titanate-impregnated zeolite. Data will be collected to analyze the effect of waste stream composition (especially the presence of complexants and colloids) on TRU removal for the most developed technology (carrier precipitation) and for the alternative technologies.
Colloids Capability. This project will establish the laboratory capability to investigate colloid formation/behavior in the supernatant. The goal is to determine the significance of sludge components in colloids, that cannot be readily separated because of their extremely small size. Colloids and radionuclides often attach to each other, making the separation/isolation/extraction of radionuclides more difficult.

\section{Hanford - Immobilization}

LLW Melter Testing. This project will conduct phased testing of melters using simulated waste feed, to provide the basis for selecting a reference melter technology to immobilize LLW. The melter vendors will produce glass with simulated waste and collect data to be used in evaluation of the melters. Melters will be evaluated for operability, maintainability, stability, footprint, maturity of the system, applicability of operation in a radioactive environment, ability to scale up capacity, and ease of decontamination. Variation of waste feeds from tanks dictate the need for a melter with adequate flexibility. Some of the issues that will be add ressed include a lack of experience in vitrification processing of high sodium and nitrate chemicals; composition uncertainties of melter feed and variability; glass product specifications based on performance are to be determined; product testing and control requirements are to be determined; ability to scale up melter design unit based on available test system.

Candidate Melter Systems Evaluations. This project will evaluate melter systems to support selection of the appropriate melter system for HLW vitrification plant design. The melter system must be selected to enable process and plant design to proceed. Activities were initiated in FY 1994 to select a melter system that will meet TPA and TWRS mission requirements to process the pretreated HLW/TRU wastes from the Hanford HLW storage tanks. A HLW Melter Selection Working Group was established to review melting technologies and assess melter systems that could be used in a planned nuclear waste vitrification facility. The goal was to recommend those technologies which have the highest potential to meet the objectives of the HLW vitrification program. Some of the recommendations made by the group were: 
- All-electric cold top melters with nickel base electrodes, developed initially at Westinghouse Hanford and further developed for worldwide use, provide a solid base technology for high-level waste vitrification.

- High melter temperatures offer the potential for large reductions in total program costs through increased melting efficiencies, higher waste loading (fewer canisters to store), less need for waste blending, and lower operating and disposal costs for fewer and smaller melters.

- Presently, scaleup of glass melters is at an experimental process, and frequently produces surprises. Full-scale testing should be undertaken as soon as it is practical to do so.

The melter system may be used to destroy offgas organic materials and cyanide in the melter feed. The high temperature in the melter and the offgas system would thermally destroy these materials. Development and analyses would be necessary to ensure the redox properties of the glass would not be affected, or could be controlled through oxidizer addition. Also, the ability of the melter system to perform to the requirements of an incinerator need to be evaluated.

LLW Packaging and Materials. This project will determine the best matrix material and/or container for long term storage of the low level waste glass. This includes compatibility testing of possible materials, and configurations to select the best method for the disposal system. The long term integrity of the material needs to be tested as well as the effects on glass durability. This will include literature searches, product testing, and selection with strong interfaces with the Performance Assessment. The materials will have to meet the requirements of the Low-Level Waste Performance Assessment and be compatible with the glass and disposal systems, while providing for retrievability. Packaging and materials to be assessed include casks, grout, ceramics, and polymers. Storage options to be considered casks, vaults, and vertical caisson storage.

\section{Hanford - Stabilization/Closure}

Vadose and Groundwater Transport Parameters. The purpose of this project is to determine the environmental impacts that could result from a LLW release. Researchers will determine LLW radioactive inventories, vadose zone transport parameters, groundwater transport parameters, dosimetry parameters, and facility dose allocation. Currently, the location of the LLW disposal facility has not been selected, facility design criteria have not been established and specification of waste forms and types of engineered barriers have not been determined. The methodology includes all aspects of the release, transport, and exposure of radionuclides. Models include waste form degradation, transport through engineered barriers, transport through unsaturated and saturated soils, transport through air, and human exposures. The methodology also addresses uncertainty and sensitivity analysis. 


\section{Idabo - Safety}

Systems Analysis Support. The state of Idaho requires that DOE cease use of some of its single shell tanks in 2009 and the remaining tanks in 2015. Current operating facilities, as configured, cannot process the liquid wastes in the existing tank farm in time to comply with the Consent Order. The current calcination process must be modified, or a new process and production facility must be constructed to remove the wastes from the tanks and condition the waste for disposal. DOE-ID has directed Lockheed Idaho to find and implement the most efficient and cost effective process for processing the HLW and sodium bearing waste inventory and ceasing use of the current Idaho Chemical Processing Plant (ICPP) tank farm.

Current analysis efforts have evaluated the 1) management options available to ICPP waste operations, 2) sodium-bearing liquid waste trearment technology alternatives, 3) calcine waste treatment technology alternatives, 4) high activity immobilization alternatives, and 5) low activity immobilization alternatives. This analysis supports the requirements to select treatment alternatives by June 1, 1995, and the technology development and implementation program planning.

\section{Idabo - Retrieval}

INEL Light Duty Utility Arm. This project supports development of Function and Requirements documents for, and provide plant review of, EM-50 development of end effectors for tank inspections. Researchers are designing and fabricating a camera system and sampler system for tank inspection and subsequent characterization. They are also designing and reviewing a nondestructive examination end effector, minilab characterization end effector (initial development provided by Sandia), and a gripper end effector. EM-30 will procure the INEL Light Duty Utility Arm for application at the ICPP tank farm for inspection and subsequent character- ization of the tanks. The arm will be used for inspection of tank walls to determine tank integrity, and characterization of waste to develop waste simulant for testing and demonstrations. The project has completed hot demonstration of Nondestructive Examination (NDE) end effectors for tank inspections, developed operating procedures and system operability tests, completed a tank condition assessment report, and developed a waste simulant.

Decontamination Development. Lockheed Idaho has been developing various decontamination techniques that are designed to either help decontaminate an empty tank or to minimize the amount of liquid added to the ICPP tank farm. Some of the developed technologies include monsodium liquid decontamination chemicals, strippable coatings, $\mathrm{CO}_{2}$ blasting, grit blasting, nondestructive concrete decontamination, laser ablation, and other innovative techniques. Recently imposed funding constraints will limit future decontamination activities.

\section{Idaho - Pretreatment}

Calcine Retrieval, Pretreatment, and Dissolution Methods. The purpose of this project is to develop and demonstrate equipment for retrieval, pretreatment, and dissolution of the calcine stored in Calcine Bin Set 1. Calcine retrieval has been demonstrated on $1 / 4$ scale models, and the information gained may be used to support a bin set 1 calcine removal project pending completion of a safety analysis and a review of stress relief options. Calcine dissolution has been demonstrated on laboratory and bench scale using simulated calcine and in a laboratory scale on actual hot calcine. Calcine blending/mixing has been demonstrated on a pilot plant scale. Researchers interface closely with Separations and immobilization personnel, to understand flow rates and product quality for the dissolution and pretreatment process.

\section{Idabo - Immobilization}

New ICPP Waste Mission Activities. The purpose of this project is to develop waste formulations and 
specifications for immobilized waste forms from the HLW fraction of a separation process and for directly immobilizing ICPP wastes. It will develop criteria for the selection of immobilization equipment, and demonstrate HLW immobilization. Expertise is leveraged by developing technologies to immobilize both liquid and calcine wastes with common equipment/processes. Researchers are also investigating HLW forms that meet repository and waste acceptance criteria. The project works closely with Separations personnel, to understand feed compositions to the HLW immobilization process.

LLW Stabilization Hot Lab Tests and Design and Build a Sodium/LLW Cold Pilot Plant. The purpose of this project is to develop, through laboratory, pilot plant, and mock-up testing; an approved, cost effective, optimized, and accepted immobilization form for low-level waste generated from the pretreatment and separations of existing and future ICPP (Idaho) radioactive sodium wastes and calcines.

Cold laboratory tests with surrogate pretreated radioactive sodium waste have been completed, with an emphasis placed on grout (cement) formulations. Glass and alternative forms are also being investigated. A conceptual design for the grout pilot plant has been completed. A Waste Acceptance Criteria draft document for a LLW disposal site is also in progress. A system analysis study has been completed which identifies cement grouting as the preferred option. 


\section{$5.3 \quad$ OAK RIDGE}

\section{ORNL - Retrieval}

Bulk Sludge Mobilization \& Slurry Transport: Enhanced Submerged Jet Sludge Mobilization \& Transport Studies. The purpose of this project is to develop enhanced submerged jet mobilization systems to mix and mobilize sludge in ORNL horizontal underground storage tanks, conduct slurry transport studies to design pipeline transport systems for ORNL Liquid Low Level Waste LLLW sludges, and evaluate industrially-available in-line solids monitoring instrumentation for ORNLLLLW sludges.

Mixing/mobilization studies have been initiated in a 1/6-scale and 2/3-scale horizontal storage tank using a simulated chemical sludge and Kaolin clay, a physical sludge simulant. Computer modelling using the PNL TEMPEST code showed that the present model accurately predicts liquid mixing, but not sludge mobilization. The model can not be used to design mobilization systems for ORNL applications without significant modification. Slurry transport studies have also been initiated with ORNL and Hanford simulants to obtain design and operating conditions for slurry pipeline transport systems. The system is being modified to obtain minimum setrling velocity data, and to test in-line solids monitors for pipeline transport of sludges.

This is a collaborative EM-30/EM-40 funded activity to meet four ORNL programs' needs. This effort leverages with studies at Savannah River and Hanford for development of submerged jet systems for vertical tanks. The development effort utilizes both ORNL and PNL development staff. Investigators interact with other retrieval technology developers at ORNL and other DOE sites to leverage when possible with their retrieval efforts.

Modified Light Duty Utility Arm (MLDUA) System Development. The Gunite and Associated Tanks Treatability Study is one of the highest priority environmental restoration projects in Oak Ridge so that clean up progress can be made in the near term. The hazards associated with these tanks are sufficiently high so that the project is likely to continue at a high priority yet sufficiently low so that clean up progress can be made in the near term. This makes the activities at Oak Ridge an excellent proving ground for technology that could then be applied to the more challenging single-shell tank clean up tasks at Hanford. This project is on an aggressive schedule with Federal Facility Agreement Milestones driving the project. A strong tie has been formed with EM-50 to leverage ongoing technology development activities.

ORNL is working with WHC, INEL, PNL, SNL, and Spar Aerospace Limited to design and build a modified version of the Light Duty Utility Arm (LDUA). The LDUA is being developed by the EM-50 Tank Focus Area (TFA) Program primarily for deployment of characterization and inspection end-effectors into the single-shell tanks at Hanford. INEL has also initiated procurement of an LDUA System for use in single shell tanks. ORNL completed an initial Feasibility Study in June of 1994 that determined that a modified LDUA system could be developed to meet ORNL retrieval system requirements. ORNL has initiated a follow on Feasibility Study with Spar to further detail the required modifications and anticipated cost for a MLDUA. In order to expand the mission of the LDUA to retrieval of Gunite tank waste, ORNL is modifying the LDUA to increase the payload capacity, shorten and stiffen the vertical positioning mast, and alter the deployment system to allow deployment via a crane lift to a bridge support structure over the tanks rather than truck-based deployment.

The bulk of the sludge in ORNL gunite tanks was removed circa 1983 using past-practice sluicing. Removal of the heel requires a remotely operable system that can be deployed throughout the tank volume to mobilize the sludge and transport it to processing equipment at the surface. The LDUA and end effectors will be used to remove the residual sludge heel in the ORNL Gunite tanks. The modified LDUA will be of sufficient payload and reach to deploy both characterization tools and waste re- 
trieval tools. Although the MLDUA cannot reach the entire tank volume of the largest tanks from a single access port, multiple ports can be installed and used by the MLDUA if this technology proves effective.

The MLDUA will be delivered to ORNL approximately June of 1996. Cold testing will be performed through September of 1996. Hot testing in the ORNL Gunite tanks will begin in October of 1996 and continue throughout FY97. This will be the first arm-based remotely operable waste retrieval system to be deployed in a large DOE underground waste tank. This is a collaborative EM- 40 / EM-50 project.

Confined Sluicing Waste Retrieval End-Effector System. This project develops a high pressure water jet waste dislodging and conveyance end effector to remove sludge waste from the Gunite tanks. This end effector will be capable of being deployed both by a modified version of the Light Duty Utility Arm, and by a smaller arm mounted on a mobile vehicle traveling in the tanks. This retrieval tool is being developed in cooperation with the EM-50 Tank Focus Area, PNL, WHC, Quest, and the University of Missouri-Rolla.

This tool will be used to remove the residual sludge heel in the ORNL Gunite ranks. The bulk of sludge was removed circa 1983 using past-practice sluicing, and part of the remaining sludge is hard material that was not mobilized during the previous sluicing campaign. Therefore a tool that can safely dislodge the remaining waste without damaging the tank is required. Removal of the heel requires a remotely operable system that can be deployed throughout the tank volume to mobilize the sludge and transport it to processing equipment at the surface. The tests performed to date indicate that a variety of waste forms can be successfully mobilized and transported out of underground storage tanks using these water jet cutting techniques. During FY95 ORNL will test those prototype systems on material that simulates the properties of the waste found in the ORNL Gunite tanks and under conditions that emulate the deployment scenarios for the Gunite tanks. During FY95 ORNL will also work on the systems design for operating these waste dislodging and conveyance tools as end-effectors on a remote deployment device.

Procurement of a field testable unit will be initiated at the beginning of FY96. This unit shall be received about June of 1996 and integrated with a deployment system at ORNL for cold testing. Cold testing will be completed by the end of FY96. Hot field testing shall begin in FY97. This is a collaborative $E M-40 / E M-50$ project.

\section{ORNL - Pretreatment}

Cesium Removal Demonstration. This collaborative EM-30/EM-50 funded task will demonstrate the use of a skid-mounted mobile ion exchange system for processing contaminated high-salt content waste from ORNL underground storage tanks. The ion-exchange system will use a sorbent selected from the results of the FY95 Tank Focus Area sorbent comparison studies (many are EM-50 developed materials) to remove radioactive cesium from 4-5M sodium nitrate. The demonstration will process up to 25,000 gallons of low level waste to meet Nevada Test Site or ORNL solid waste disposal facilities waste acceptance criteria. The loaded resins will be vitrified at Savannah River as a leveraged demonstration. The demonstration will determine processing capabilities, identify potential operating/maintenance problems for remotely operated mobile ion exchange systems, and demonstrate decontamination of the system for potential use at other sites. The project also considers issues such as worker health and safery, costs, disposal site waste acceptance criteria, and storage capacity limitations.

Project scoping, planning, and preliminary system design will be completed in FY96. The demonstration will be primarily in FY97. After final demonstration, the unit will be transitioned to EM-30 for incorporation into baseline processing, or used to demonstrate separations capabilities of superior ion exchange materials being developed by EM-50 Efficient Separations Program.

Out of Tank Evaporator Systems Demonstration. This collaborative EM-30/EM-50 funded task will demonstrate the use of skid-mounted evaporator for processing $25,000 \mathrm{gal}$ of contaminated high-salt 
content waste from ORNL underground storage tanks. The evaporator will remove excess water for ORNL LLLW, a $4 \mathrm{M}$ sodium nitrate solution contaminated primarily with cesium and strontium. The demonstration will determine processing capabilities, identify potential operating/maintenance problems for remotely-operated evaporators, and demonstrate decontamination of the system for potential use at other sites. The demonstration will be completed in FY96. Reports will be written and the system will be transferred to EM-30 for ongoing operation in FY96.

\section{ORNL - Immobilization}

Dried/Melted Saltcake Studies - Wiped Film Evaporator/Microwave Melter. The purpose of this project is to perform cold demonstrations to design equipment and set operating conditions and ranges for treatment of ORNL TRU sludges for disposal at WIPP. This includes use of a wiped film evaporator and microwave melter to produce a $\mathrm{dried} / \mathrm{melted}$ saltcake which will meet WIPP acceptance criteria. The wiped film evaporator is used for slurry concentration in industrial applications, because of its high heat transfer properties. The microwave melter is a technology developed by DOE and has the advantage of having no moving parts in the remote operated area. Researchers interface with technology developers at ORNL EM-30, EM-40, EM-50 TFA and ESP, and other DOE sites to leverage when possible with their immobilization technology development efforts.

NAC/NAG Waste Form Studies. This task will leverage with $E M-50$ program to determine if the Nitrate to Ammonia and Ceramic (or Glass) (NACl NAG) process can be used to treat mixtures of ORNL legacy and newly-generated waste to remove nitrate and meet on-site waste disposal criteria. The process will be evaluated for removal of nitrate from ORNL LLLW to meet on-site waste acceptance criteria for the range of ORNL waste streams. This treatability study will be completed in FY95. 


\subsection{SAVANNAH RIVER}

SRS - Safety

Metallurgical and Equipment Engineering Assistance. This task provides metallurgical, equipment engineering, and process support to ensure safe storage of materials in tanks. Researchers will provide analysis and inspection techniques to ensure continued safe storage of materials in tanks, build and test new Continuous Air Monitor (CAM) design, and develop and test an annulus video system and crawler to replace the still camera.

Defense Waste Processing Facility (DWPF) Safety/ Process Envelope. This task will define key safety related process conditions, requirements and limits within which the DWPF will operate in addition to those limits set by Operational Safety Requirement. It will provide a sound, technical bases for preparation and completion of the DWPF Safety Analysis Report.

Manage System Generated Waste. This program requires the safe handling, processing, and storage of waste generated from the DWPF process. Major tasks include collecting, treating, and discharging all radioactivity contaminated process waste from the HLW system; Packaging, characterizing, and shipping solid waste in a manner that meets solid waste disposal acceptance criteria; collecting, treating, monitoring, and discharging gaseous effluents generated from HLW processing operations; collecting organic effluents, treating as required to meet disposal facility criteria, and storing for processing/disposal.

\section{SRS - Characterization}

Develop and Upgrade Defense Waste Processing Facility (DWPF) Analytical Methods. The purpose of this project is to deliver accurate and efficient analytical methods to meet DWPF requirements for process control and process history/diagnostics. Research tasks include developing cesium removal methods to reduce dilutions and exposure, identifying and developing methods for organic detection in DWPF recycle to ensure safe recycle to the tank farm, evaluating improved methods for phenylboric acid in Salt Cell product to reduce analytical time, and evaluating slurry sampling and dissolution techniques to reduce analytical time. Accurate analytical methods unique to waste vitrification are required to meet stringent quality controls imposed by Waste Compliance. Methods for radioactive operation are not fully tested, and current chemical methods are very time consuming. Due to this problem, DWPF Laboratory capacity becomes a processing bottleneck.

\section{SRS - Retrieval}

Equipment Engineering Support. The purpose of this project is to provide equipment engineering support to ensure integrity of process transfer systems. Major tasks include developing improved techniques and equipment for salt sampling and salt mining, developing removal techniques for mining equipment, and developing riser probing technique for pump installation.

Waste Removal. The purpose of this project is to provide solutions for removing waste (salt and sludge) from existing underground storage tanks for transfer to pretreatment facilities. Major tasks include determining salt dissolution kinetics, evaluating pump operation and installation requirements, develop methods to remove mixed salt and sludge, develop methods to remove dry/hardened sludge, and develop methods to remove tank heels.

\section{SRS - Pretreatment}

In-Tank Precipitation. This project treats salt solution to remove cesium by precipitation with sodium tetraphenylborate (STPB), and to remove soluble strontium, uramium, and plutonium by absorption on monosodium titanate. Major tasks include providing feed and hold tank pump operating strategy to minimize foaming and temperature buildup, demonstrate filter cleaning techniques, and support benzene abatement technology. 
Precipitate Washing. The purpose of this project is to provide analytical, metallurgical, and process support to ensure In Tank Precipitation (ITP) washing meets processing and safety requirements. Major tasks include developing hot cell techniques and evaluating samples to ensure the process meets performance requirements, evaluating reduced inhibitor requirements for washed precipitate storage to minimize nitrite addition, and defining pitting corrosion rates to determine inhibitor requirements and tank life.

Late Wash. This project provides analytical and process support to late wash design and USC field demo. Major tasks include quantifying the effects of insoluble particles on late wash filtration, conducting filtration tests on the Experimental Lab Filter (ELF) (especially duplicating cleaning cycle) and developing a model of the dynamic backpulse systems used to clean filters, designing an on-line nitrite/benzene monitors for Late Wash,

Sludge Washing. The purpose of this project is to provide analytical, metallurgical, equipment engineering and process development to ensure sludge washing meets DWPF and safety requirements.

\section{SRS - Immobilization}

Glass Composition Formulation. The purpose of this project is to determine the characteristics of an effective glass waste form. This will include formulating high- and low-temperature laboratory glasses and characterizing properties such as melt viscosity and electrical conductivity as functions of temperature, glass composition and durability, product consistency of quenched and canister centerline cooled glass, transition temperature, crystallinity as a function of temperature, and redox. Researchers will develop predictive models, incorporate experimental data into the glass property models where there is insufficient data, and compare experimental glass properties with properties predicted theoretically. An important part of the work will be to assess expected waste feed compositions for both desired constituents and critical minor components with the greatest potential impact on waste loading and glass durability.
Glass Sampling and Testing. This project will demonstrate that the waste glass meets the Waste Acceptance Product Specifications. It must be demonstrated that the glass product meets the specifications in order for Radioactive Operations to begin. Major tasks include performing Product Consistency Testing (PCT), SEM and X-Ray Diffraction analyses on glass grab and canister glass samples, determining the chemical composition and exrent of crystallization of glass samples, and measuring the glass transition temperature, volatility, viscosity, and liquids of glass samples.

Hydrolyze Tetraphenylborate (TPB). This project provides a technique to remove organics (primarily benzene) from the precipitate slurry from Late Wash before transferring material to the Chemical Processing Cell. Major tasks include effectively implementing the SRTC technology and pilot scale test experience to the field, conducting bench and pilot scale runs in the Precipitate Hydrolysis Experimental Facility (PHEF), and developing a process for cleaning the Salt Process Cell vent.

Prepare Melter Feed. This project provides a method to blend and process the precipitate hydrolysis aqueous and washed sludge from the Tank Farm with frit. Major tasks include conducting bench and pilot scale Integrated DWPF Melter System (IDMS) runs with simulants to model planned DWPF operation, defining DWPF recycle stream flows and compositions, determining nitroaromatic concentration in DWPPF recycle streams, developing a reference process for cleaning the Chemical Process Cell vent along with addressing the method to dispose cleaning solution(s), and reducing DWPF sampling and Melter Feed System bias.

Saltstone Formulation. This project provides the technology to receive salt solutions from In-Tank Precipitation and effluent treatment operation. Major tasks include receiving dry feed materials, blending, and transferring to the premix feed bin; mixing salt solution and premix to produce grout, pumping grout to the disposal vaults, and backfilling around the vaults and capping with a layer of clean grout. 


\section{SRS - Stabilization/Closure}

Vault Closure. The purpose of this project is to provide closure design support and performance assessment modeling to ensure Saltstone vault closure meets regulatory requirements. Researchers will provide performance requirements for new vault structure, address issues required for final approval of radiological performance assessment and maintain radiological performance assessment, and conduct groundwater sampling and lysimeter studies 


\section{9 uọ̣oas}

\section{SHILINALAOddO SSANISAg GOA}




\section{WORKING WITH THE DOE OFFICE OF ENVIRONMENTAL MANAGEMENT}

DOE provides a range of programs and services to assist universities, industry, and other private-sector organizations and individuals interested in developing or applying environmental technologies. Working with DOE Operations Offices, as well as management and operating contractors, EM employs a number of mechanisms to identify, integrate, develop, and adapt promising emerging technologies. These mechanisms include contracting and collaborative arrangements, procurement provisions, licensing of technologies, consulting arrangements, reimbursable work for industry, and special consideration for small business. EM facilitates the development of subcontracts, R\&D contracts, and cooperative agreements to work collaboratively with the private sector.

\section{COOPERATIVE RESEARCH AND DEVELOPMENT AGREEMENTS (CRADAS)}

CRADAs are mechanisms for collaborative $R \& D$. They are agreements between a $D O E R \& D$ laboratory and any non-federal source to conduct cooperative R\&D that is consistent with the laboratory's mission. The partner may provide funds, facilities, people, or other resources. DOE provides the CRADA partner with access to facilities and expertise; however, external participants receive no federal funds. Rights to inventions and other intellectual property are negotiated between the laboratory and the participant. Certain generated data may be protected for up to five years. Several companies may combine their resources to address a common technical problem. Funds can be leveraged to implement a consortium for overall program effectiveness.

\section{PROCUREMENT MECHANISMS}

DOE-EM procurement mechanisms are for technology development in the form of unsolicited proposals and formal solicitations, although the latter are preferable. The principal contractual mechanisms used by EM for industrial and academic response include Research Opportunity Announcements (ROAs) and Program R\&D Announcements (PRDAs).

EM utilizes the ROA to seek advanced research and technologies for a broad scope of cleanup needs. The ROA supports applied research ranging from concept feasibility to full-scale testing. In addition, the ROA is open continuously for a full year following the date of issue and includes a partial procurement set-aside for small businesses. Typically, ROAs are published annually in the Federal Register, announced in the Commerce Business Daily, and provide multiple awards.

PRDAs are program announcements which solicit a broad mix of advanced development and demonstration proposals. A PRDA requests proposals for a wide-range of technical solutions to specific EM problem areas. Multiple awards, which may have distinct approaches or concepts, are generally made. Numerous PRDAs may be issued each year.

EM awards grants and cooperative agreements if $51 \%$ or more of the overall value of the effort is related to a public interest goal. Such goals include possible non-DOE or other federal agency participation and advancement of present/future U.S. capabilities in domestic and international environmental cleanup markets. They may also include technology transfer, advancement of scientific knowledge, or education and training of individuals as well as business entities. 


\title{
For more information about PRDAs and ROAs, contact:
}

\author{
Tom Martin \\ U.S. Department of Energy \\ Morgantown Energy Technology Center \\ P.O. Box 880 , MS 107 \\ Morgantown, West Virginia 26507
}

(304) $285-4087$

\section{LICENSING OF TECHNOLOGIES}

DOE contractor-operated laboratories can license DOE/EM-developed technology and software. In situations where DOE retains the ownership of a new technology, the Office of General Counsel will serve as the licensing agent. Licensing activities are conducted according to existing DOE intellectual property provisions.

\section{TECHNICAL PERSONNEL EXCHANGE ASSIGNMENTS}

Personnel exchanges provide opportunities for scientists from private industry and DOE laboratories to work together at various sites on environmental restoration and waste management problems. Private industry must contribute substantial cost-sharing for these personnel exchanges. To encourage such collaboration, the rights to any resulting patents go to the private sector company. These personnel exchanges, which can last from three to six months, result in the transfer of technical skills and knowledge.

\section{CONSULTING ARRANGEMENTS}

Laboratory scientists and engineers are available to consult in their areas of technical expertise. Most contractors which operate laboratories have consulting provisions. Laboratory employees who wish to consult can sign non-disclosure agreements, and are encouraged to do so.

\section{REIMBURSABLE WORK FOR INDUSTRY}

DOE laboratories are available to perform work for private industry and other federal agencies, as long as the work pertains to the mission of a respective laboratory and does not compete with the private sector. The special technical capabilities at DOE laboratories are incentives for the private sector to use DOE's facilities and contractor expertise. An advanced class patent waiver gives ownership of any inventions resulting from the research to the participating private sector company.

\section{INTERACTIONS WITH SMALL BUSINESSES}

EM seeks the participation of small businesses in its RDDT\&E programs (1) through collaborative efforts with the National Laboratories, or (2) directly via solicitations issued by the DOE Small Business Innovation Research (SBIR) Program Office and the Small Business Technology Transfer (T2) Pilot Program (STTR). EM also has established a partial procurement set-aside for small firms (500 employees or less) for applied research projects through its ROA. 
For further information about SBIR and STTR programs, please contact::

\author{
U.S. Department of Energy \\ Small Business Innovation Research Program Hotline \\ ER-16 GTN \\ Washington, D.C. 20585 \\ (301) $903-5707$
}

\title{
EM CENTER FOR ENVIRONMENTAL MANAGEMENT INFORMATION
}

The EM Center for Environmental Management Information is designed to provide ready access to prospective research and business opportunities in waste management, environmental restoration, and decontamination and decommissioning activities. The Center can identify links between industry technologies and program needs. It connects potential partners to an extensive complex-wide network of DOE headquarters and operations office contacts.

To reach the EM Center for Environmental Management Information, call 1-800-736-3282.

\section{OFFICES OF RESEARCH AND TECHNOLOGY APPLICATIONS}

The Offices of Research and Technology Applications (ORTA) serve as technology transfer agents for the federal laboratories. They coordinate technology transfer activities among laboratories, industry, and universities. ORTA offices license patents and foster communication between researchers and technology customers.

\section{ORTA CONTACTS:}

\section{Laboratory}

Ames Laboratory

Argonne National Lab

Brookhaven National Lab

Fermilab

Idaho National Engineering Lab

Lawrence Berkeley Lab

Lawrence Livermore National Lab

Los Alamos National Lab

Morgantown Energy Technology Ctr

National Renewable Energy Lab

Oak Ridge Institute/Science \& Ed $\underline{\text { Contact }}$

Todd Zdorkowski

Shari Zussman

Margaret Bogosian

John Vernard

Ann Rydalch

Cheryl Fragiadakis

Dave Conrad

Pete Lyons

Rodney Anderson

Dana Moran

Mary Loges
Phone Number

(515) 294-5640

(708) 252-5361

(516) 282-7338

(708) 840-2529

(208) $526-1010$

(510) 486-6467

(510) 422-7839

(505) 665-9090

(304) 285-4709

(303) 275-3015

(615) 576-3756 


\section{$\underline{\text { Laboratory }}$}

Oak Ridge National Lab

Pacific Northwest Lab

Pittsburgh Energy Technology Center

Princeton Plasma Physics Lab

- Sandia National Lab

Savannah River Technology Center

Stanford Linear Accelerator Center

Westinghouse Hanford Company
Contact

Bill Martin

Marv Clement

Kay Downey

Lew Meixler

Warren Siemens

Jack Corey

Jim Simpson

Dave Greenslade
Phone Number

(615) $576-8368$

(509) 375-2789

(412) 892-6029

(609) 243-3009

(505) 271-7813

(803) $725-1134$

(415) $926-2213$

(509) $376-5601$ 


\section{ACRONYM LISTING}

Section 7.0 
ANL Argonne National Laboratory

ALARA As Low As Reasonably Achievable

CEA Commissariat ç l'Energie Atomique (France)

CERCLA Comprehensive Environmental Response, Compensation, and Liability Act

CFR Code of Federal Regulations

CRADA Cooperative Research and Development Agreement

DoD Department of Defense

DOE Department of Energy

DWPF Defense Waste Processing Facility

EM Office of Environmental Management

EM-30 Office of Waste Management

EM-40 Office of Environmental Restoration

EM-50 Office of Technology Development

EM-52 Office of Technology Transfer and Program Integration

EM-53 Office of Research and Development

EM-54 Office of Demonstration, Testing, and Evaluation

EM-60 Office of Facility Transition and Management

ERT Electrical Resistance Tomography

ESP-CP Efficient Separations and Processing Crosscutting Program

FFA Federal Facility Agreement

FFCA Federal Facility Compliance Act

FIU Florida International University

FSU Florida State University

FTIR Fourier Transförm Infrared

GTM Generic TRUEX Model

HLW High-level waste

HTB Hydraulic test bed 
ID

INEL

IP

ISU

ITP

LANL

LDUA

LLNL

LLW

LRF

$\mathrm{M} \& \mathrm{O}$

METC

MIT

MTI

MVST

NAC

NIR

NJIT

NSF

ORNL

OTD

PAS

PNC

PNL

PRDA

$R \& D$

RDDT\&E

ROA

SERDP
Integrated Demonstration

Idaho National Engineering Laboratory

Integrated Program

Iowa State University

In-Tank Precipitation

Los Alamos National Laboratory

Light Duty Utility Arm

Lawrence Livermore National Laboratory

Low-Level waste

Laser Range Finder

Management and Operations

Morgantown Energy Technology Center

Massachusetts Institute of Technology

Mechanical Technology Incorporated

Melton Valley Storage Tanks

Nitrate to Ammonia and Ceramic

Near-Infrared

New Jersey Institute of Technology

National Science Foundation

Oak Ridge National Laboratory

Office of Technology Development

Photoacoustic Spectroscopy

Power Reactor and Nuclear Fuel Development Corporation

Pacific Northwest Laboratory

Program R\&D Announcement

Research and Development

Research, Development, Demonstration, Testing, and Evaluation

Research Opportunity Announcement

Strategic Environmental Research and Development Program 
SKID Skid-Mounted Ion Exchange Demonstration

SRS Savannah River Site

SRTC Savannah River Technology Center

TBP Tributyl Phosphate

TFA Tank Focus Area

TPA Tri-Party Agreement

TRIC Tank Riser Interface and Confinement

TRU Transuranic

TTP Technical Task Plan

TWR Tank Waste Remediation

TWRS Tank Waste Remediation System

UI University of Idaho

USC University of South Carolina

UST Underground Storage Tank

WD\&C Waste Dislodging and Conveyance

WHC Westinghouse Hanford Company

WMRAD Waste Management and Remedial Action Division

WSRC Westinghouse Savannah River Company 


\section{APPENDIX}

\section{Section 8.0}




\subsection{APPENDIX}

Technical Task Plans (TTPs) identify and summarize funded work managed by OTD at headquarters, the field and the national laboratories. All tasks require a TTP number, which contains eight characters assigned by DOE Headquarters. The format consists of two alpha characters followed by six numerical characters. Characters 1 and 2 designate the DOE Operations Office/Funding Allotment Code. Character 3 denotes the laboratory/contractor/university designator. Character 4 denotes the fiscal year in which the task is first funded. The below characters reflect TTPs from FY94-95.

Characters $1,2 \& 3$

ALO Albuquerque Operations Office

ALI Los Alamos National Laboratory (LANL)

AL2 Sandia National Laboratories, Albuquerque (SNLA)/Martin Marietta

AL3 Sandia National Laboratories, Livermore (SNLL)

AL4 Kansas City Plant (KCP)/Allied-Signal Aerospace

AL9 RUST GEOTECH

CHO Chicago Operations Office

CH1 Ames Laboratory

$\mathrm{CH} 2$ Argonne National Laboratory (ANL)/University of Chicago

CH3 Brookhaven National Laboratory (BNL)/Associated Universities, Inc.

CH5 National Renewable Energy Laboratory

FN0 Fernald Environmental Management Project (FEMP)

FN1 Fluor Daniel Environmental Restoration Management Company

HQ0 OTD Headquarters

IDO Idaho Operations Office

ID1 Idaho National Engineering Laboratory (INEL)/EG\&G

ID4 Westinghouse Idaho Nuclear Company

ID6 Babcock \& Wilcox, Inc

ID7 Lockheed Idaho Technology Company

ME0 Morgantown Energy Technology Center (METC)

NV0 Nevada Operations Office

OHO Ohio Operations Office

OH1 Fernald Environmental Management Project (FEMP) 


$\begin{array}{ll}\text { OH2 } & \text { EG\&G Mound Applied Technologies } \\ \text { OR0 } & \text { Oak Ridge Operations Office } \\ \text { OR1 } & \text { Martin Marietta Energy Systems (MMES) } \\ \text { OR3 } & \text { Oak Ridge Institute for Science and Education } \\ \text { PE0 } & \text { Pittsburgh Energy Technology Center } \\ \text { PE1 } & \text { MSE, Inc. } \\ \text { RF0 } & \text { Rocky Flats Environmental Technology Office } \\ \text { RF1 } & \text { Rocky Flats Plant/EG\&G } \\ \text { RL0 } & \text { Richland Operations Office } \\ \text { RL2 } & \text { Kaiser Engineers Hanford Company (KEH) } \\ \text { RL3 } & \text { Pacific Northwest Laboratory (PNL)/Battelle Memorial Institute } \\ \text { RL4 } & \text { Westinghouse Hanford Company } \\ \text { SF0 } & \text { Oakland Operations Office } \\ \text { SF1 } & \text { Lawrence Berkeley Laboratory (LBL)/University of California } \\ \text { SF2 } & \text { Lawrence Livermore National Laboratory (LLNL)/University of California } \\ \text { SF3 } & \text { Energy Technology Engineering Center (ETEC) } \\ \text { SR0 } & \text { Savannah River Operations Office } \\ \text { SR1 } & \text { Westinghouse Savannah River Company (WSRC) }\end{array}$


Character 4

1

2

3

4

5

6

7

8

9

0

FY 1991

FY 1992

FY 1993

FY 1994

FY 1995

FY 1996

FY 1997

FY 1998

FY 1999

FY 2000 